\title{
Guise and Disguise Before and During the Tanzimat
}

In 1911, French war illustrator Georges Bertin Scott de Plagnolle (1873-1943) was entrusted by Henri Moser with producing colour images for a portfolio presenting his Middle Eastern arms and armour displayed at Charlottenfels, the "castle," or rather mansion, which he had bought in Neuhausen (Switzerland) and where he had installed a fumoir arabe [Islamic style smoking room]. Scott brings colour and detail to the type of display favoured by many collectors throughout the nineteenth century. (Fig. 140) Sets of vibrant draperies and rugs hang in order to orientalise the armoury. The room is replete with artefacts. The plate creates an image of plentifulness. Daggers are aligned in glass cases or arranged in mural trophies, while sets of armour are worn by papier mâché mannequins. Other illustrations in the book show mannequins mounted on horses. All were crafted by the Parisian firm Georges Hallé Fils \& Successeur. ${ }^{1}$ In the background, one can discern the owner himself by one of his cuirasses. His likeness is modelled after a photograph of Moser in travelling garb, a fur-lined kaftan [from the Persian khaftān] worn over capacious embroidered pants with a cashmere shawl tied around the waist. (Fig. 141)

Curios, atmospheric rooms and matching attire constitute an association found across many collections. The trilogy of space, artefact and garb substantiates the artifice of verisimilitude. It represents a rhetorical device meant to bring decontextualised inanimate articles into living existence. Moser recalls "sitting alone one evening at dusk in [his] armoury," imagining "a nocturnal ambuscade," when, "suddenly the arms seemed to become imbued with life." ${ }^{2}$ The idea of inert

1 Francine Giese, "International Fashion and Personal Taste," 104.

2 Henri Moser, Collection Henri Moser-Charlottenfels, Armes et armures orientales (Leipzig: Hiersemann, 1912), v. objects coming to life in one's reminiscence of past events is a trope that has already been encountered in the words of artist Fortuny (Chapter 1) and that of architect Baudry (Chapter 4). The artefacts' physical arrangements were meant to facilitate that process. In his reflections on museology, Lockwood de Forest insisted that the "nearer you can get the surroundings which belong with the objects, the more effective they are." An enthusiastic supporter of the Musée de Cluny in Paris, de Forest recalled sitting there on an old bench and feeling the "atmosphere of the Middle Ages." Dress was an integral part of the method deployed by private and public collectors alike in order to reclaim the past into the present. It had the power to vivify emotions.

Islamic collectibles thus intersect not only with the materiality of their physical setting, as seen in the previous chapter, but indeed with dress protocols matching the immersive displays that were made for them. As we shall see in the course of this chapter, "sartorial Orientalism" 4 did take place within such atmospheric rooms. The setting was, more often than not, costume balls and live performances in Middle Eastern disguise. The writer Pierre Loti (1850-1923) gained a reputation for the lavish Arab and Turkish parties he gave in the style rooms that he installed from 1877 to 1906 in his family house in Rochefort (south western France). Loti himself delighted in posing in the clothes brought back from his travels to the Middle East: a set of photographs depicts him in 1892 dressed

3 Washington, DC, Smithsonian Institution, Archives of American Art, Lockwood de Forest papers, Box 2, Folder 10, Museum Management, June 1919, f. 3 .

4 The phrase is borrowed from Marie-Cecile Thoral, "Sartorial Orientalism: Cross-cultural dressing in colonial Algeria and metropolitan France in the nineteenth century," European History Quarterly 45, no. 1 (2015): 57-82.

(C) MERCEDES VOLAIT, 2021 | DOI:10.1163/9789004449886_007 


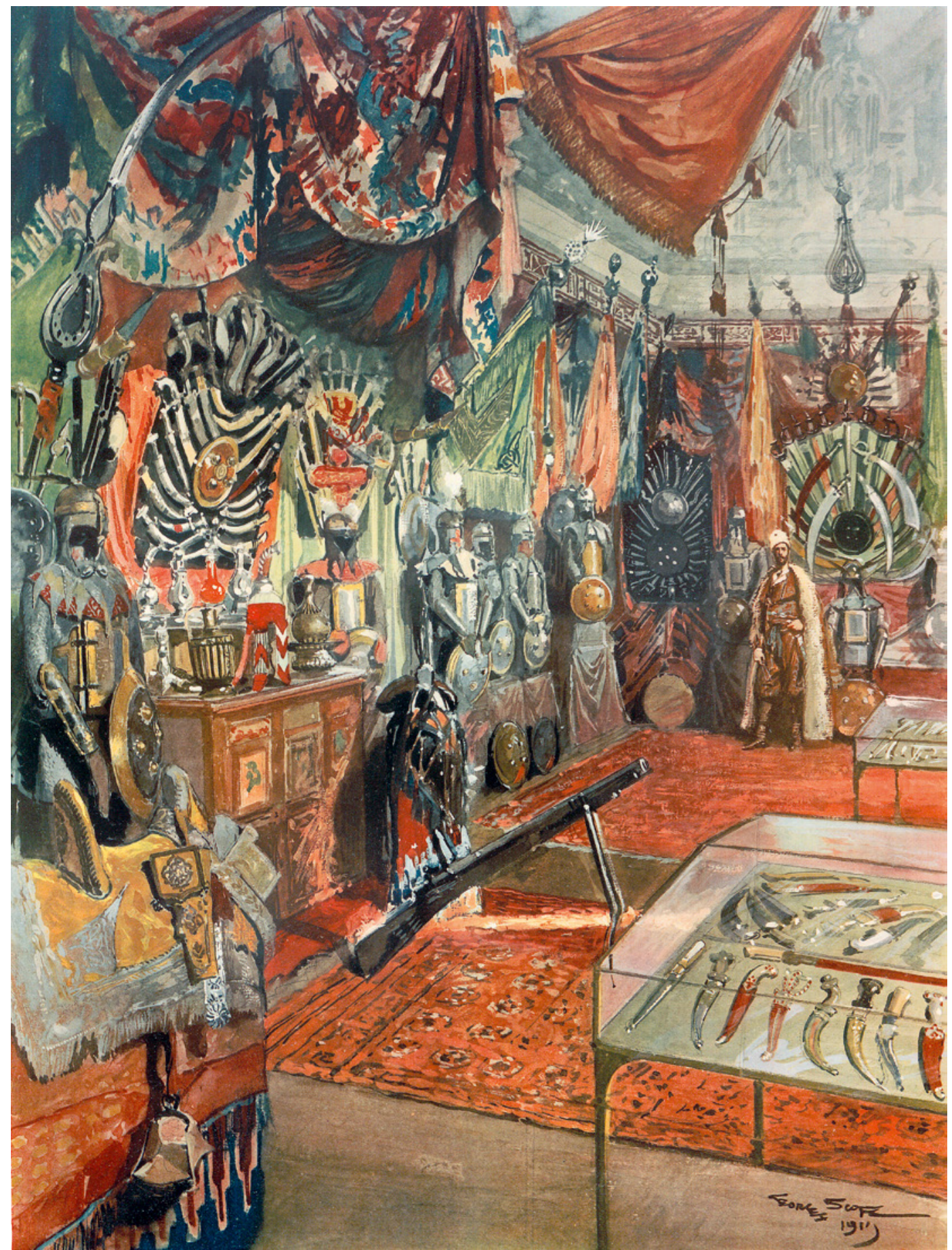

FIGURE 140 Georges Bertin Scott, Oriental armoury at Charlottenfels, 1911. Chromolithograph HENRI MOSER, COLLECTION HENRI MOSER-CHARLOTTENFELS, ARMES ET ARMURES ORIENTALES 1912: PL. 1 


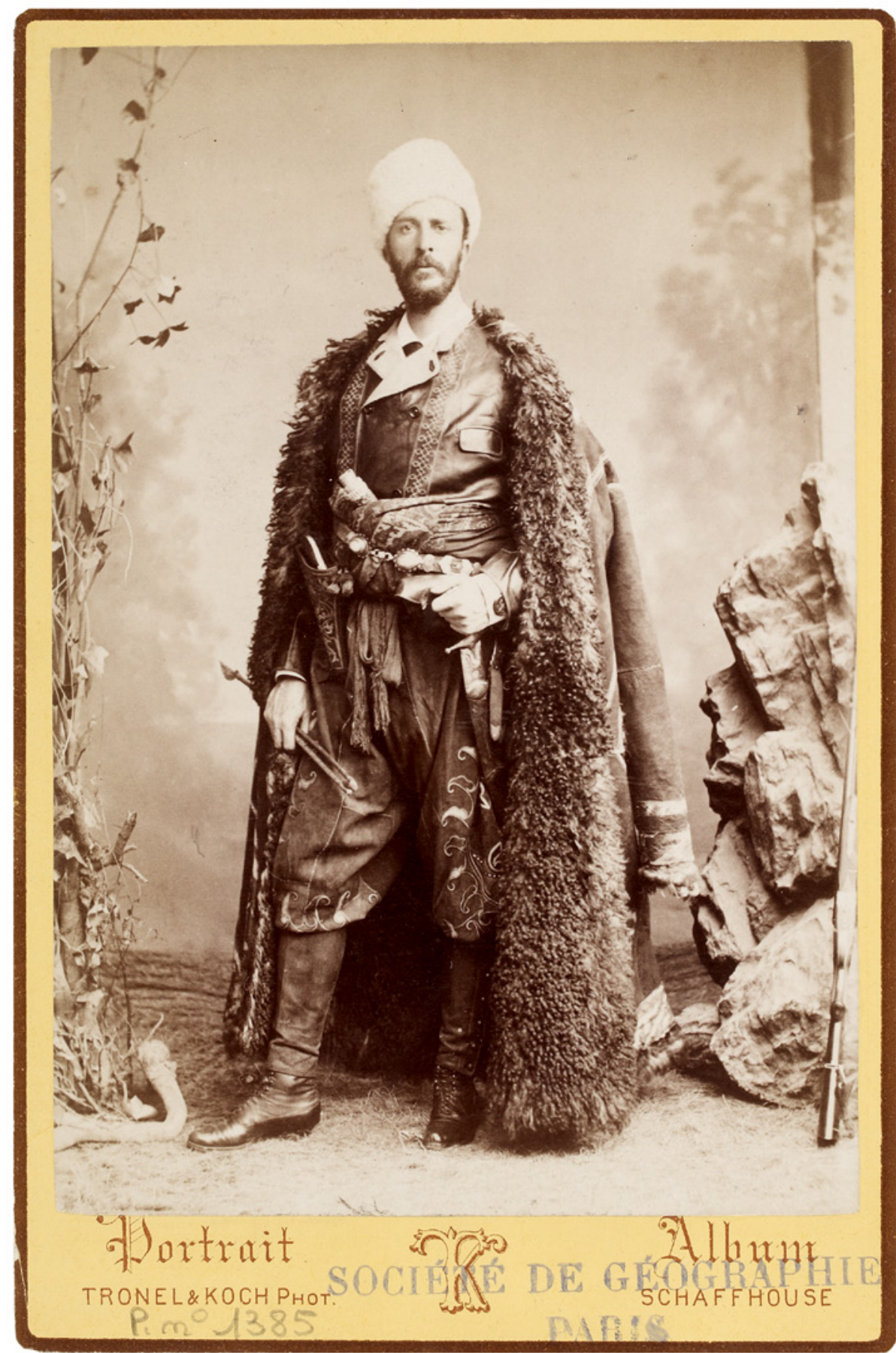

FIGURE 141

Tronel \& Koch (Schaffhouse), Portrait of Henri Moser in carte de visite format, before 1884. Albumen print on card. $6 \times 9 \mathrm{~cm}$

PARIS, BIBLIOTHÈQUE NATIONALE DE FRANCE, SOCIÉTÉ DE GÉOGRAPHIE, SG PORTRAIT-1385 
as an "Arab Warrior", reclining in his Arab den, and as an "Emir" in the fictional mosque where he mourned Aziyadé, the alleged Turkish love of his life. 5

It was indeed the spirit of the age in Europe to consider architecture and apparel in conjunction. Auguste Racinet (1825-93), the distinguished author of the six-volume Le Costume historique (1888), an illustrated global survey of attire across time and place, explicitly linked clothing and dwelling in the very subtitle of his magnum opus: Types principaux du vêtement et de la parure rapprochés de ceux de l'intérieur de l'habitation dans tous les temps et chez tous les peuples, avec de nombreux détails sur le mobilier, les armes, les objets usuels, les moyens de transport. ${ }^{6}$ All chapters included notes and images of characteristic domestic architecture in the places represented. To antiquarians, attire was a prime cultural marker. It represented solid empirical evidence from which to reconstruct past societies, as architects and archaeologists did for the Middle Ages. ${ }^{7}$ François Pouillon has shown that fabric and garb can be an apt golden thread to explore the labyrinth of intercultural experiences

5 Bruno Vercier et al., La Maison de Pierre Loti à Rochefort (Paris: Editions du patrimoine, 1999), 11; and for an inspired personal essay about a visit made in 1937, Marcel Schneider, "Pierre Loti à Rochefort," Revue des deux mondes (June 1989): 161-71.

6 Auguste Racinet, Le Costume historique: cinq cents planches, trois cents en couleurs, or et argent, deux cents en camaïeu, types principaux du vêtement et de la parure, rapprochés de ceux de l'intérieur de l'habitation dans tous les temps et chez tous les peuples, avec de nombreux détails sur le mobilier, les armes, les objets usuels, les moyens de transport, etc. (Paris: Firmin-Didot, 1876-88).

7 Françoise Tetart-Vittu, "Auguste Racinet," in Dictionnaire critique des historiens de l'art actifs en France de la Révolution à la Première Guerre mondiale, eds. Philippe Sénéchal and Claire Barbillon, [https://www.inha.fr/fr/ ressources/publications/publications-numeriques/ dictionnaire-critique-des-historiens-de-l-art/racinet -auguste.html?search-keywords=Racinet]; Odile Blanc, "The historiography of costume: A brief survey," in Ottoman Costumes, from Textile to Identity, eds. Suraiya Faroqhi and Christoph K. Neumann (Istanbul: Eren, 2004), 49-62. and engagements. ${ }^{8}$ Following his lead, this chapter thus intends to connect Islamic style interiors with cross-cultural dressing, labelled by some ethnomasquerade, ${ }^{9}$ in order to assess the analytical added-value brought by looking into their combinations and interactions.

There is no lack of visual documentation and textual evidence to conduct the enquiry, whatever the recognised shortcomings and ambiguities of the material. As well established, images do not always, or not solely, represent what they pretend to depict. ${ }^{10}$ However, close examination, in combination with cross-checked information and expanded contextualisation, allows us to extract relevant clues and access pertinent meanings.

In the past few decades, a large body of literature has engaged with cross-cultural dressing during, and since, the Enlightenment, as part of a broader interest in historic and global dress. The following is an attempt to distinguish, on the one hand, timelines and tropes based on overviews and discussions of sartorial experimentation by Europeans on both sides of the Mediterranean in pre-Tanzimat times. It aims on the other to examine what can be reconstructed specifically about "dressing native,"11 to borrow John Rodenbeck's phrase, in nineteenth-century Egypt from travel narratives and imagery. It finally charts some of the uses of Middle Eastern attire encompassed by European visual arts during the same period.

8 François Pouillon, "Le fil d'Ariane," in François Pouillon, Exotisme et intelligibilité: Itinéraires d'Orient (Pessac: Presses universitaires de Bordeaux, 2017), 133-49, initially published as "Collections, travestissements, dévoilements: notes anthropologiques sur l'exostime textile et vestimentaire," in Touches d'exostime, ed. Sylvie Legrand (Paris: Musée de la mode et du textile, 1998), 207-17.

9 Kader Konuk, "Ethnomasquerade in OttomanEuropean encounters: Reenacting Lady Mary Wortley Montagu," Criticism 46, no. 3 (2004): 393-414. On the possibilities and pitfalls of visual evidence, Peter Burke, Eyewitnessing: The Uses of Images as Historical Evidence (London: Reaktion Books, 2001).

11 John Rodenbeck, "Dressing native," in Unfolding the Orient, Travellers in Egypt and the Near East, eds. Paul and Janet Starkey (Reading: Ithaca Press, 2001), 65-100. 


\section{Codification and the Intricacies of Cross-Cultural Dressing in Pre-Tanzimat Times}

The European embrace of Middle Eastern attire during the nineteenth century was certainly not a new phenomenon, nor an exclusive one. It is closely tied to, and marked by, eighteenth-century culture, when it had been competing with other fashions, such as clothing all'antica. A most famous Enlightenment visual testament of the latter type of fancy dressing is Gavin Hamilton's canvas James Dawkins and Robert Wood Discovering the Ruins of Palmyra (1758, National Gallery of Scotland) where the two British antiquarians approach the ancient site dressed in togas. The Roman cloth was meant to match the archaeological remains visited. The contrast with the costumes of their Turkish escorts (allegedly no fewer than 300 guards!) is all the more striking. ${ }^{2}$

The reasons that induced Europeans to dress in Ottoman garb for travel, portraiture, public performance, or daily life, are manifold. Some instances had implicit political messages. Romanticism and displays of distinction were known motivations, as was the culture of spectacle. Convenience mattered too. The etiquette of dress in the Eastern Mediterranean had a say indeed. European crossovers did not intervene in a vacuum; they took place in the context of strict dress codification across Islamic lands. Cross-cultural dressing was not always voluntary but imposed.

\subsection{A Realm of Codified Attire}

The most obvious dress-codes in the Eastern Mediterranean were the ones imposed on nonMuslims since at least the eighth century. Typical limits on attire encompassed the ban on wearing white turbans or donning yellow slippers; green was also a colour reserved for Muslims, as were, as a general rule, bright tones. Non-Muslims were to wear black slippers and dark, black or navy, robes. These prescriptions were enforced to greater or lesser extents. Edicts commanding

12 Jason M. Kelly, The Society of Dilettanti (New Haven and London: Yale University Press, 2009), 140-43. obedience to dress restrictions and complaining of their being ignored are said to have been strikingly frequent during Ottoman times, suggesting that infringements were common. At the borders of the Sultanate, practices of clothing and arming the body have been shown to be fluid and permeable, to the point of creating a "muddling of costume and identity" that blur conventional categorisations. ${ }^{13}$ Rules allowed for exceptions too, such as when local Christians and Europeans transited through dangerous areas; in such circumstances, they were permitted to dress as Muslims to avoid potential assault. Cross-dressing was not always an option; in this case, it was a required precaution. The effectiveness of the artifice is another story, as shall be seen below. Still, clothing protocols long represented a common culture across the Empire. Sartorial impositions were not fully abolished until the Imperial Rescript of 18 February 1856 proclaimed equal rights and honour of all Ottoman citizens. ${ }^{14}$

Garb and headgear restrictions for non-Muslims developed within broader norms of etiquette and identification that applied to all classes of society and activity in the Ottoman world. As a result, Ottoman or Turkish attire generated a whole realm of images: from the sixteenth century onwards, countless costume books or costume illustrations were produced. The former were primarily popularised in Europe in print form, while the latter were authored by the so-called bazaar artists in Istanbul and were primarily meant for export as detached leafs or bound albums. Recycling the technique of the Islamic miniature, they aimed to document the distinct attire commanded by rank, office and religion, not to speak of gender and ethnicity, in Ottoman society. ${ }^{15}$ They were

13 Robyn Dora Radway, "Vernacular Diplomacy in Central Europe: Statesmen and soldiers between the Habsburg and Ottoman Empires, 1543-1593" (Phd Diss., Princeton University, 2017), chapter 5 passim.

14 Matthew Eliott, "Dress codes in the Ottoman Empire: the case of the Franks," in Ottoman Costumes, eds. Faroqhi and Neumann, 103-23.

15 For the most recent assessment regarding later compendiums, Elisabeth Fraser, "The Color of the Orient: On Ottoman Costume Albums, European Print Culture, and Cross-Cultural Exchange," in Visual 
crafted supposedly from life, but more often than not from codified types, and were intended both for European and Ottoman audiences. A plea has been convincingly made to consider these collections individually, as specific patronage is strongly evident in their compilation, while their reception singles out distinct publics. ${ }^{16}$ Yet at a broader level, costume books and albums do share the commonality of presenting series of single human figures standing against a plain background, with brief labels identifying their status or function. (Fig. 142) The genre persisted well beyond the eighteenth century as a Turkish compendium of Ottoman costumes produced for the Vienna Universal exhibition in $1873,{ }^{17}$ and Auguste Racinet's endeavour, exemplify. (Fig. 143) Both were based on thorough observation. The latter used the black and white photographs engraved in the former, and added the colours from actual costumes seen at the 1874 annual exhibition of UCAD in Paris. ${ }^{18}$ As a type of image, the costumed characters were in a way the ancestors of the genre of "Types and scenes" mass-produced by colonial photography and postcards in the nineteenth century and well into the twentieth century. Their respective audiences were very different however. Costume albums and books were exclusive goods, only affordable to the fortunate few. Postcards were products for mass consumption.

\subsection{Defying Prohibitions or Mediating Private Affairs?}

Many Ottoman costume recollections were actually made for, or acquired by, European envoys to the Porte. Their iconography was an efficient guide to the hierarchies of Ottoman society, helping diplomats to properly identify the dignitaries with

Typologies from the Early Modern to the Contemporary, Local Contexts and Global Practices, eds. Tara Zanardi and Lynda Klich (New York: Routledge, 2018), 45-58. Gwendolyn Collaço, "Dressing a city's demeanour: Ottoman costume albums and the portrayal of urban identity in the early seventeenth century," Textile History 48, no. 2 (2017): 248-67.

Osman Hamdy and Marie de Launay, Les Costumes populaires de la Turquie en 1873 (Istanbul: n.p., 1873).

18

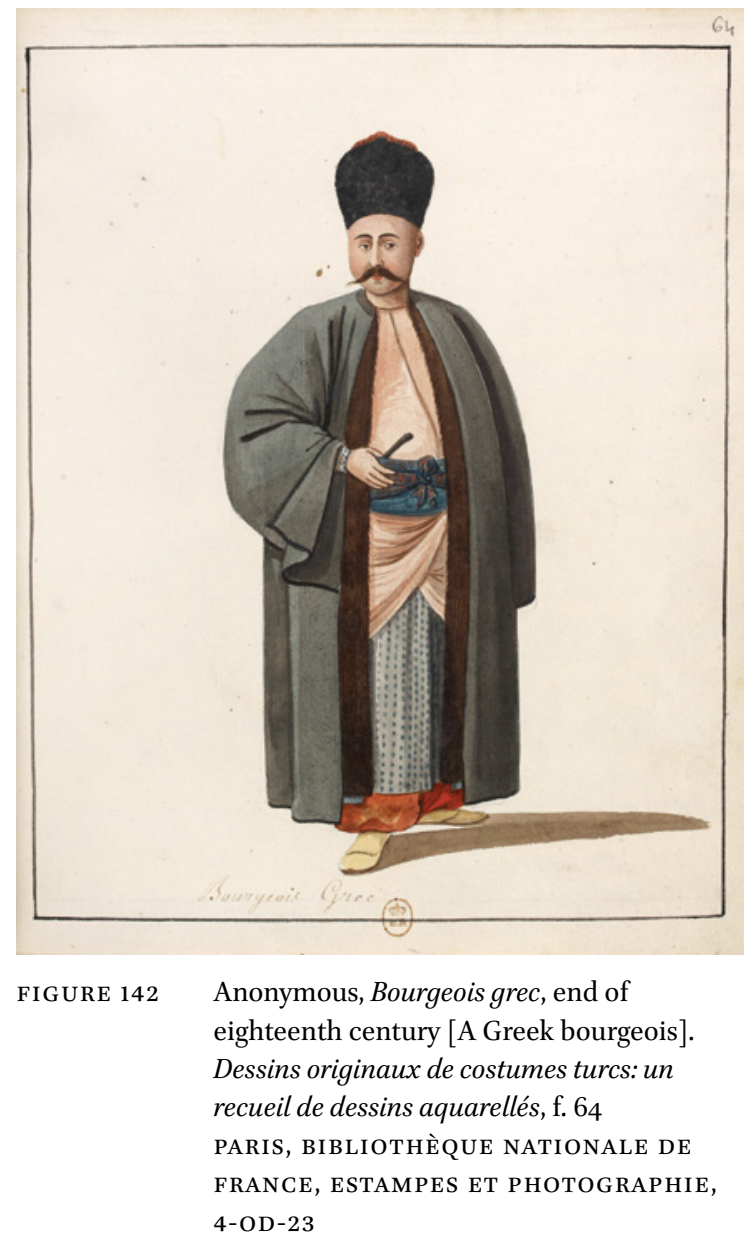

whom they were to interact during their sojourns, ${ }^{19}$ as well as the diverse groups forming the society they were to encounter. The visual volumes made appealing souvenirs in return. Once ambassadors were back from their postings, the codices served to memorialise the time spent abroad, and contributed to self-promotion when the images were shared at social gatherings. Portraiture in (sumptuous) Ottoman attire was another frequent practice for the diplomats (and traders) who had gone East. ${ }^{20}$ Interpretations suggest that through such

19 Soraya Faroqhi, "Introduction, or why and how one might want to study Ottoman clothes," in Ottoman Costumes, $15^{-48}(20)$.

20 Joachim Gierlichs, "Europeans in 'Turkish' Dress," in Fashioning the Self in Transcultural Settings: the Uses and Significance of Dress in Self-Narratives, eds. Claudia Ulbrich, Richard Wittmann (Würzburg: Ergon-Verlag, 2015), 151-86. 


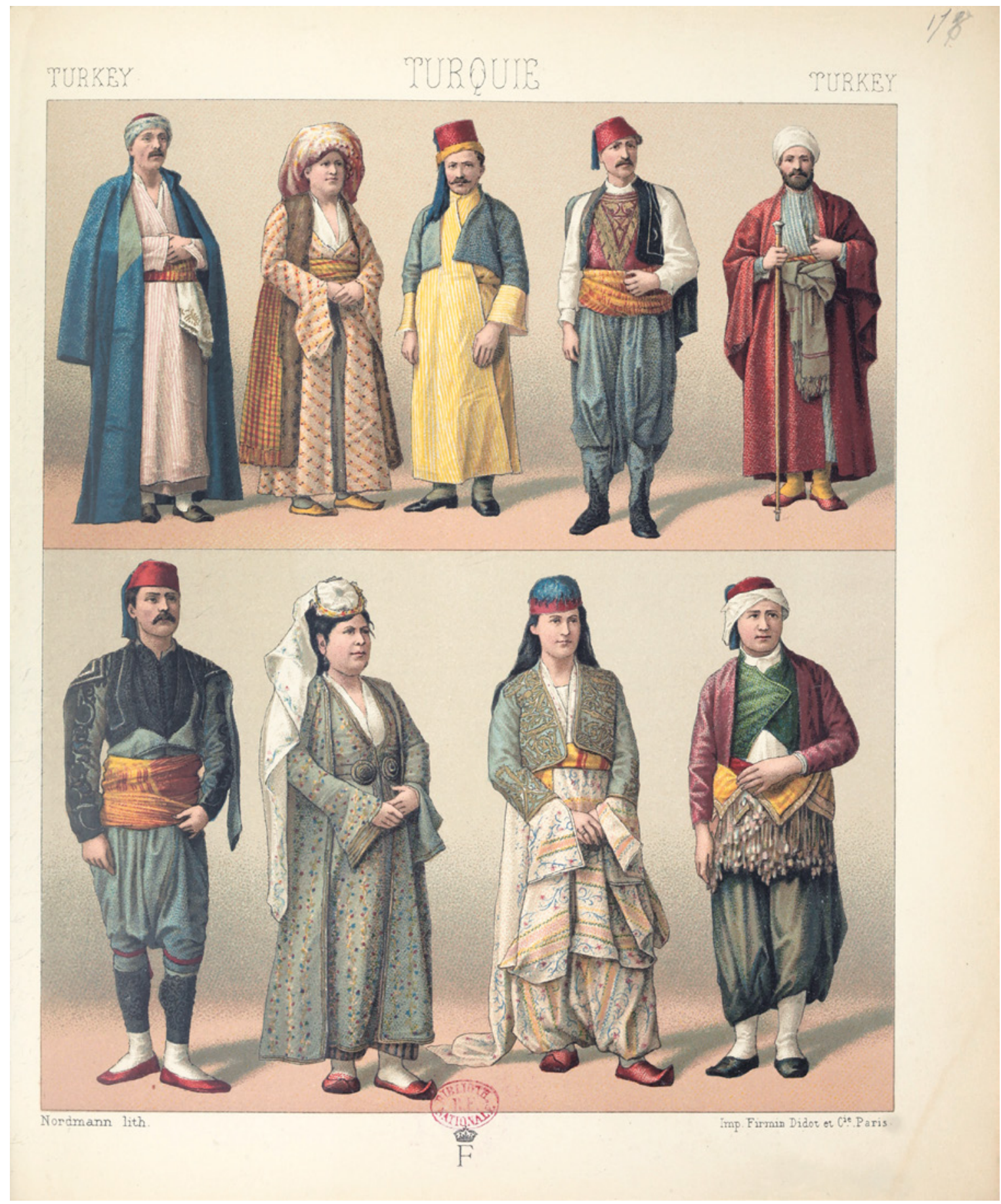

FIGURE 143 Auguste Racinet, attr., Turquie, Asiatiques turcomans, chrétiens et israélites, vilayet de Houdavendighiar (Brousse), d'Aidinet de Koniah. Muslim, Jewish and Christian costumes in the wilaya of Bursa. On the upper row, left to right: an inhabitant of El-Maly, a Jewish woman from Bursa, an artisan from Aïdin, a groom from Bursa, a Jewish scholar from Smyrna; on the lower row: a couple from Bursa in marriage costume, a Muslim woman from Bursa, a Christian merchant from Aïdin LE COSTUME HISTORIQUE..., 1876-88, III: PL. 178 
gestures, often in life-size format, sitters intended to make outwardly visible the elevated status acquired abroad; being depicted in Oriental garb was a way to project a well-travelled persona and the authority of experience. Under this rationale, Orientalist portraits are to be understood as "public performances," whose assertive power was directed at Western viewers, rather than Ottoman ones, contrary to what has been long assumed..$^{21}$ In the context of the clothing restrictions imposed on non-Muslims, one cannot but question the measure of defiance involved in the act of crossdressing. Was dressing native, i.e. dressing Muslim, a way to visually challenge prohibitions and the authority of the Porte? At times, however, motivations may just have obeyed more intimate concerns, as the following case suggests.

An enigmatic instance of alla turca portraiture, slightly unsettling in its strangeness, is a likeness of the Chevalier de Vergennes (1719-1787) painted in Istanbul by French artist Antoine de Favray in 1766. (Fig. 144) The French aristocrat had been the ambassador of Louis XV to the Porte since 1755 . $\mathrm{He}$ is depicted sitting against richly patterned cushions, one foot tucked under a bent leg, a posture akin to local habit, found in many Ottoman portraits. $^{22}$ The Rocaille style panelling in the background follows French contemporary interior design. The gilded moulding features a discernible fleur de lys, the typical French regalia, but the combination of deep green and gold can indeed be considered a nod to classical Ottoman embroidered velvets. The ambassador is dressed in a red kaftan trimmed with ermine over a robe made of radiant yellow silk brocade with floral buds woven into it, and a pale blue one; he wears the typical scarlet şalvar [baggy trousers] and yellow slippers. Brown fur envelopes him, possibly belonging to the rose-coloured marten-lined mantle of

21 Tara Mayer, "Cultural cross-dressing: Posing and performance in Orientalist portraits," Journal of the Royal Asiatic Society 22, no. 2 (April 2012): 281-98.

22 Later examples include a portrait of Selim III, by Konstantin Kapodagli (Topkapi Palace in Istanbul) and of Yusuf Agha effendi by Carl Fredrik von Breda, 1794-96 (Pera Museum, Istanbul). honour provided for his audience with the Sultan upon his arrival. ${ }^{23}$ Vergennes's headgear consists of a white turban wrapped around a red toque, the quilted cap known as kavuk. A dagger set with gems is slipped into the sash tied around his waist. He holds a chibouk in one hand and a rosary in the other. Two pocket watches with stylised Indian numerals rest by his hand on the cushion. The article was much in fashion across the Ottoman Empire since the 1740s; most were manufactured by British watchmakers involved in a considerable export trade to Turkey, such as the firm Markwick Markham. ${ }^{24}$ Did he use two in daily life? Did he collect the items?

Every detail - the bright colours, the layered fabrics, the jewelled dagger, and the elaborate cap - replicates the outfit worn by high dignitaries at the Ottoman court, if not that of the Sultan himself. The similitude is corroborated both by depictions in costume albums and contemporary portraiture. Several plates of the widely circulated Recueil Ferriol (1714), a series of engravings commissioned by a previous French ambassador to the Porte, Charles de Ferriol, feature similar accoutrements. ${ }^{25}$ More significantly, a life-size portrait, dated 1742, of Said Pasha, who became grand vizier of the Ottoman Empire shortly after Vergennes's arrival in Istanbul, displays very similar attire. ${ }^{26}$ Later compendiums confirm the

23 Louis Bonneville de Marsangy, Le Chevalier de Vergennes. Son ambassade à Constantinople (Paris: E. Plon, 1894), I: 163 .

24 G.H. Baillie, Britten's Old Clocks and Watches and their Makers, A Historical and Descriptive Account of the Different Styles of Clocks and Watches of the Past in England and Abroad (London: Eyre and Spottiswoode, 1956, 7 th edition), 95-6.

25 Recueil de cent estampes représentant les diverses nations du Levant, tirées d'après nature en 1707 et 1708 par les ordres de M. de Ferriol, ambassadeur du Roy à la Porte, et gravées en 1712 et 1713 par les soins de Le Hay (Paris: Le Hay et Duchange, 1714), pl. 2, 14, 39; on its wide circuation, Jeff Moronvalle, "Le Recueil Ferriol (1714) et la mode des turqueries," Dix-huitième siècle 44, no. 1 (2012): 425-46.

26 Jacques Aved, Said pacha, ambassadeur de la porte ottomane, $1742(238 \times 161 \mathrm{~cm}$, Versailles, musée national des châteaux de Versailles et de Trianon, MV 3716). 


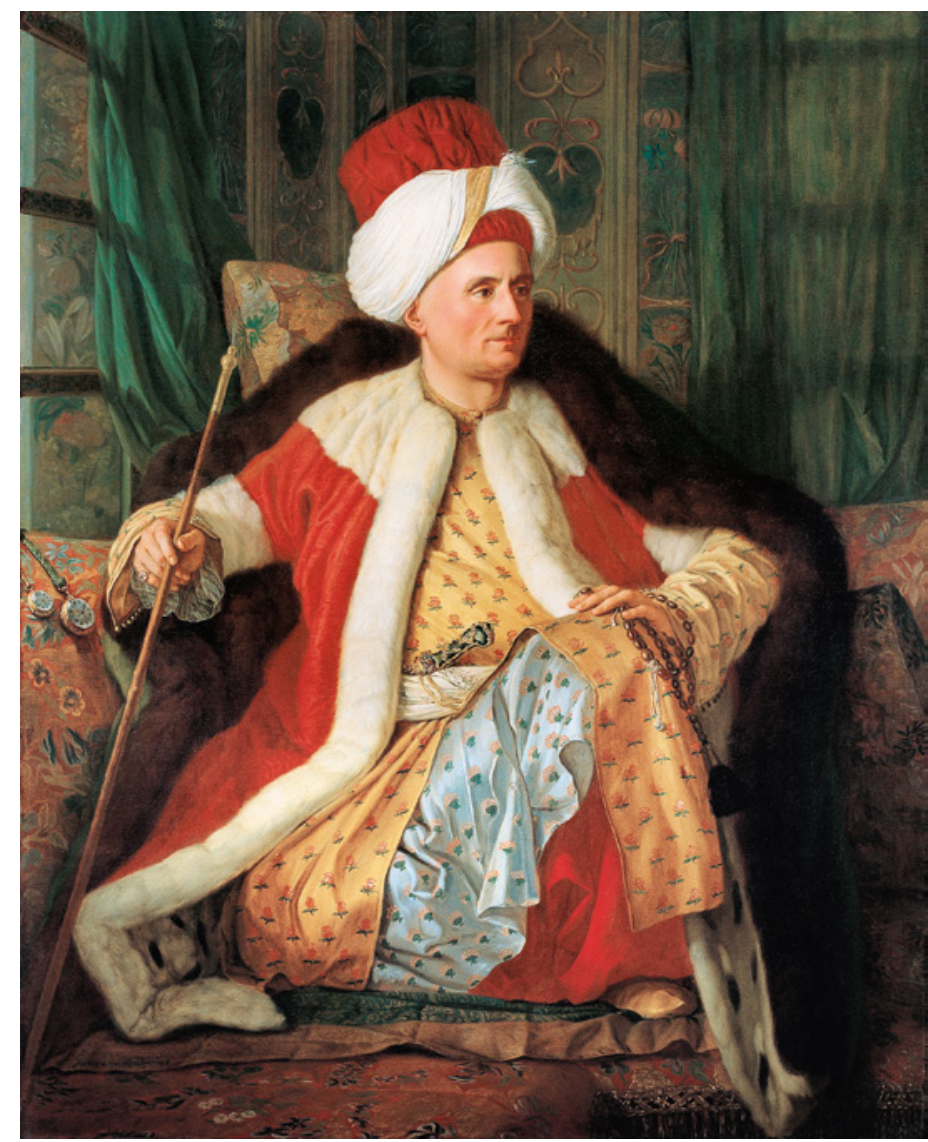

FIGURE 144

Antoine de Favray, M. de Vergennes, ambassadeur de France en costume turc, 1766. French ambassador Count de Vergennes in Turkish attire. Oil on canvas. $140 \times 112 \mathrm{~cm}$ ISTANBUL, PERA MUSEUM, SUNA AND INAN KIRAÇ FOUNDATION

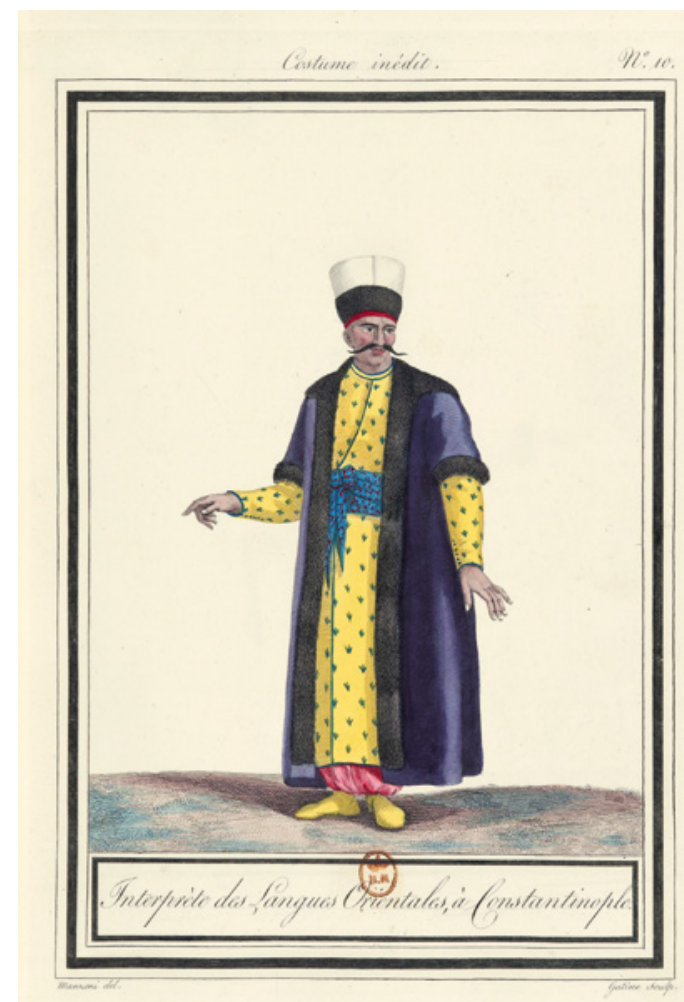

FIGURE 145

Manzoni, Interprète des langues orientales à Constantinople, end of eighteenth century. [An interpreter in Istanbul]. Costumes orientaux inédits, dessinés d'après nature en 1796, 1797, 1798, 1802 et 1808, gravés à l'eau-forte avec des explications 1813: Pl. 10

PARIS, BIBLIOTHÈQUE NATIONALE DE FRANCE, ESTAMPES ET PHOTOGRAPHIE, 4-OD-24 


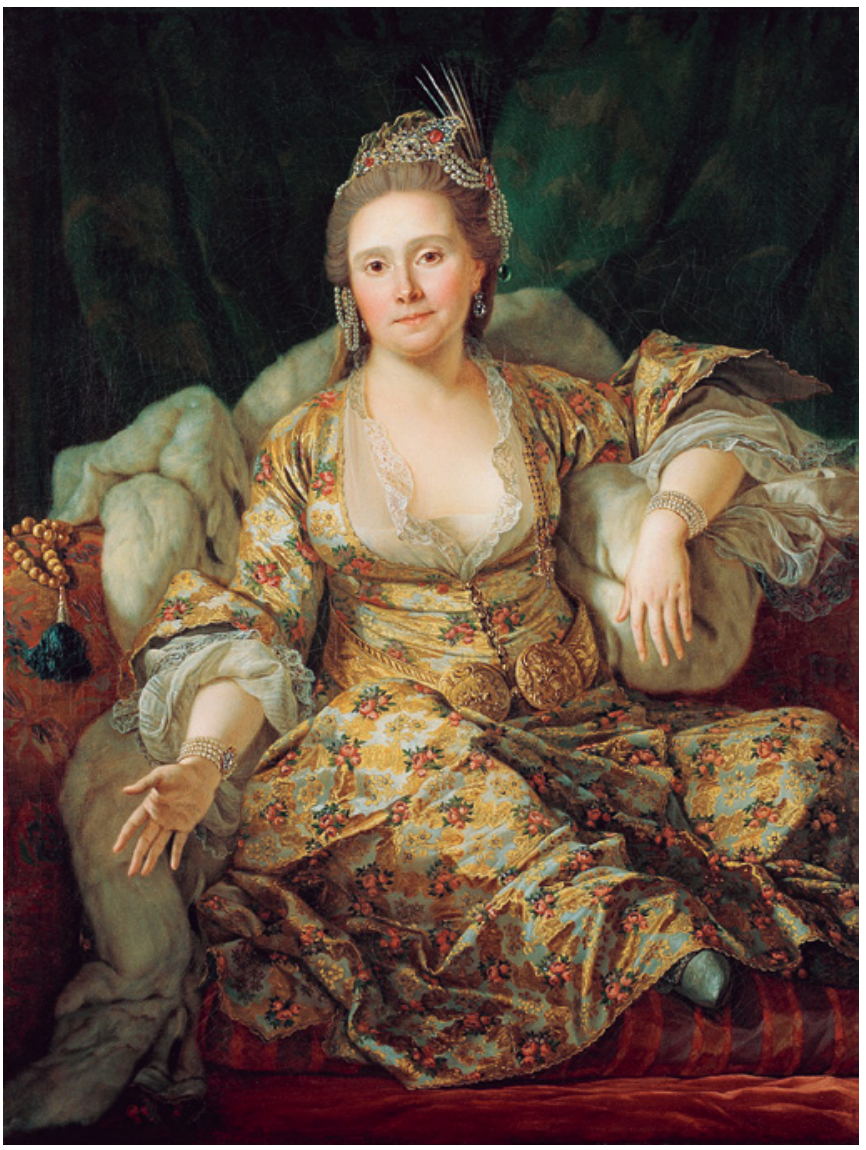

FIGURE 146

Antoine de Favray, Madame de Vergennes, en costume oriental, s.d. [Portrait of the Countess of Vergennes in Oriental attire]. Oil on canvas, $129 \times 93 \mathrm{~cm}$ ISTANBUL, SUNA AND INAN KIRAÇ FOUNDATION, PERA MUSEUM

documentary minutiae of Favray's painting, as similar fabrics, such as the yellow embroidered robe, or the red and white headgear, can be encountered among the illustrations. (Fig. 145) An identical type of wardrobe, but of different colour, together with corresponding props (chibouk and rosary), were used by the Swiss artist Jean-François Liotard, also based in Istanbul, in his double portrait Monsieur Levett et Mademoiselle Glavani en costume turc (c. 1740). The painting shares a connection with Favray's piece through the diplomatic sphere, for Miss Glavani was the daughter of the then French consul. Apart of being a signifier of status, rich Turkish clothing within European diplomacy in Istanbul was not exceptional. ${ }^{27}$

27 Mark Fehlmann, "Orientalism," in Jean-Étienne Liotard (1702-1789) (London: Royal Academy of Arts and National Galleries of Scotland, 2015), 65-87.
When looking closer (or rather zooming in on a digital reproduction of the canvas), Vergennes's incorporation of the Turkish habit, in the double sense of costume and custom, does not appear limitless. The most obvious deviation is the cleanshaven chin - an actual Ottoman high official will have been moustached and bearded. The sitter holds a rigid, almost hieratic, pose that conveys a sense of performing formal representation. His gaze is not frontal. Should the attitude be understood as the artist's attempt to capture some embarrassment at the accoutrement? Or was it just a mean to convey the sense of decorum?

A pendant was painted by the same artist, seemingly two years later; it portrays Vergennes's long-time, but newly espoused (1767), beloved companion, Anne Viviers (1730-98). (Fig. 146) The setting bears commonalities: a low cushioned sofa is placed against a green background. The fabric 
of the cushions and the identical rosary provide a direct visual link to her husband's portrait. The sitter is richly dressed in a densely patterned gown, probably made from Lyons silk brocade. The fabric is typical of the French Rococo style; compositions with multi-coloured floral springs, here flowing along a chequered grid, were of the latest fashion in France in the 176 os. $^{28}$ The tight bodice with very open neck, the double, scalloped sleeve ruffles, the large golden belt with two circular plaques, and the ample volume of the lower part of the dress, all correspond to the guises donned by Liotard's Levantine sitters. ${ }^{29}$ (Levantines, in this instance, designating Catholics who had settled in the Empire, spoke local languages besides theirs, and had adopted some local mores. $)^{30}$ It is congruent with the attire appearing in other Levantine portraits by Favray. ${ }^{31}$ What is unusual here is the invisible şalvar, customarily worn under female gowns, and the green buckle shoes that clearly point to a French type. Thus, the picture is not technically speaking a portrait in Turkish attire, as is generally assumed, ${ }^{32}$ but one in composite apparel that mixes Ottoman and French fashion. Perhaps not insignificantly, a connoisseur labelled it as Madame de Vergennes, en costume oriental, while her husband's portrait was captioned M. de Vergennes, ambassadeur de France, en costume turc. ${ }^{33}$ Madame de Vergennes's clothing is embellished by lavish jewellery on her hair, ears and wrists. In striking contrast with her husband, she lays with apparent comfort on the couch, staring with confidence at the viewer. Her hands are depicted delicately; her opened right palm performs the welcoming gesture ascribed to nobility in contemporary royal portraiture. ${ }^{34}$ Her likeness radiates the embodiment of honourable and warm feminity.

Her situation sheds very different light on the medium-size canvas $(1.29 \mathrm{~m}$ by $0.93 \mathrm{~m})$ whose dimensions suggest that it was made for remembrance rather than to make an impression. Anne Viviers was actually a local member of Istanbul society. She was born in Pera, the city's cosmopolitan neighbourhood, to a modest French émigré and a Greek mother, and had been widowed at twenty-four years old by a member of a prominent French family of Istanbul. ${ }^{35}$ As a Levantine, she was accustomed to wearing local garb. Her usual way of sitting was cross-legged on low sofas. ${ }^{36}$ In other words, her portrait in Levantine outfit does not qualify as cross-cultural dressing; it corresponded to routine clothing, if in this instance in a more flamboyant mode. Because of their unequal social ranks, Vergennes had long kept their bond secret. Their marriage had taken place without
28 Natalie Rothstein, Silk Designs of the Eighteenth Century: in the Collection of the Victoria and Albert Museum, London: with a complete catalogue (London: Thames and Hudson, 1990).

29 Jean-Étienne Liotard, 78-84, 189.

$30 \quad$ Oliver Jens Schmitt, Les Levantins: cadres de vie et identités d'un groupe ethno-confessionnel de l'empire ottoman au "long" $19^{e}$ siècle, translated from German by Jean-François de Andria (Istanbul: Isis, 2007). Semra Germaner, Zeyneb Inankur, Constantinople and the Orientalists (Istanbul: Türkiye Iş Bankasi Kültür Yayınları, 2008), 162-3.

Intersecting Worlds, Ambassadors and Painters: ambassador portraits and art patronage of ambassadors from the 17th to the 19th century with works selected from Suna and Inan Kıraç Foundation Orientalist Paintings Collection, ed. Baris R Kibris (Istanbul: Pera Museum, 2014), 53-7.
33 Auguste Boppe, Les Peintres du Bosphore au XVIII siècle (Paris: Hachette, 1911), 97.

34 The sultanic figures in the Recueil Ferriol are good examples, as well as the portraits of Queen Marie Leszczinska; Jennifer G. Germann, Picturing Marie Leszczinska (1703-1768): Representing Queenship in Eighteenth-century France (Burlington, VT: Ashgate, 2015).

35 Orville T. Murphy, Charles Gravier, Comte de Vergennes: French Diplomacy in the Age of Revolution, 1719-1787 (Albany: State university of New York press, 1982), 165-71.

36 "Elle était ordinairement assise sur un sopha à la manière des tailleurs, dont elle se redressait avec adresse," Jean-François Labourdette, Vergennes, Ministre principal de Louis XVI (Paris: Éditions Desjonquères, 1990), 5 o. 
the King's consent and was to remain private. ${ }^{37}$ Vergennes' attempts to introduce her in diplomatic society had turned sour in more than one occasion. A guest recalls an incident at a reception the ambassador himself had organised in Istanbul:

On fut fort étonné dans une fête que donna M. de Vergennes, de voir cette femme, magnifiquement vêtue, enfairepubliquementles honneurs. Tous les ministres étrangers, qui y avoient été invités, s'en trouvèrent offensés et voulurent s'en aller. M. de Vergennes les retint, en leur disant que c'étoit Mme la Comtesse de Vergennes, ambassadrice de France, qu'il avait l'honneur de leur présenter. ${ }^{38}$

Their double portrait in (Ottoman) ceremonial garb may be reminiscent of, and in conversation with, that disparaging episode. Favray does picture Anne Viviers as "attired superbly," and with an amicable gesture, an appropriate attitude for an ambassador's wife at a public appearance, possibly her first one after her marriage to Vergennes. In this perspective, the pendant portraits would be a visual reassertion of their bond. Vergennes's averted gaze can be (re)interpreted accordingly. He may just be watching her, in loving admiration or reassurance. As there are no available text to confirm the speculation, what artist and sitters really intended with this double iconographic statement may remain a mystery. But considering portraiture with the knowledge of biography and other events demonstrates that the European

37 Murphy, Charles Gravier, 165-71; it ultimately brought disfavour to the diplomat. Vergennes was hastened to leave Istanbul one year after marrying Anne Viviers and was denied a post for several years afterwards.

38 Pierre Victor de Besenval, Mémoires de M. Le baron de Besenval (Paris: F. Buisson, 1805), II: 221. "People were astonished to see, at a party given by M. de Vergennes, this woman, superbly attired, appear in public. All foreign ambassadors among the guests felt offended and wished to leave. Mr de Vergennes held them back, telling them that it was the Countess de Vergennes, the French ambassadress, whom he was honoured to introduce to them." [My translation] wearing of Ottoman attire can be more complex and meaningful than one expects.

\subsection{The Culture of Fancy Dressing in Europe}

Many other examples of Ottoman clothing in European portraiture lack the realism encountered in the Vergennes' pendant portraits because they relate to masquerade culture. An accepted form of social transgression originating from the Italian tradition of carnevale, masked and costumed events enjoyed tremendous popularity in eighteenth-century Britain and France, and beyond. Masquerade played a subversive role in the Enlightenment imagination through its association with the crossing of class, gender and cultural boundaries, sexual licentiousness, and the "overthrow of decorum."39 It experienced prolific reception, aristocratic and popular alike, in the following century.

From the outset, masquerading à la turque in reality (performance) and representation (portraiture) was a prime subgenre for expressions of personal and national identities. The phenomenon was ultimately about oneself and was not solely frivolous. Ottoman disguise in London was performed at dedicated clubs such as the Divan Club, functioning in 1744-46; it involved gentlemen who had sojourned in the Ottoman Empire and took on seriously the pursuit of acquiring knowledge of its history and culture. ${ }^{40}$ The famous Orientalist Richard Pococke, portrayed in Ottoman attire by Liotard in 1740, was a founding member. Portraits in Turkish guise were also commissioned from the same artist by members of the Society of Dilettanti. This convivial dining society formed in 1732 by elite young men who had travelled the

39 Terry Castle, Masquerade and Civilization: The Carnivalesque in Eighteenth-century English Culture and Fiction (Stanford, CA: Stanford University Press, 1986), viii.

40 Vanessa Alayrac Fielding, "Sultans, nababs et mandarins: les enjeux du travestissement oriental en Angleterre," special issue "L'attrait de l'Orient," XVIIXVIII: Revue de la société d'études anglo-américaines des XVII e et XVIII ${ }^{e}$ siècles 67 (2010): 45-66. 


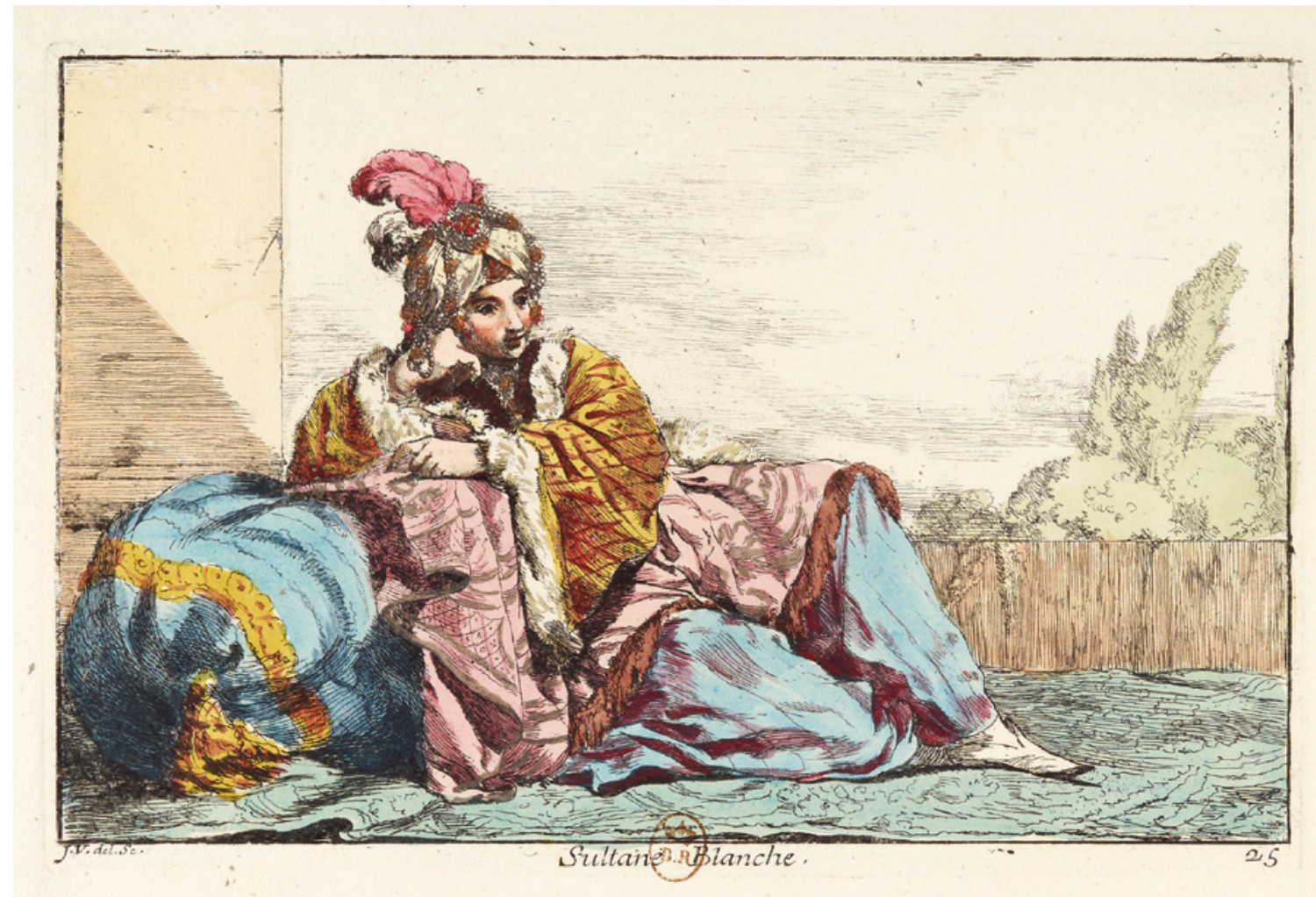

FIGURE 147 Joseph-Marie Vien, Sultane blanche. The costume is donned by a male artist from the French Academy in Rome on the occasion of the 1748 carnival. La Caravane du Sultan à la Mecque: mascarade turque faite à Rome par Messieurs les pensionnaires de l'Académie de France et leurs amis au carnaval de l'année 1748: Pl. 25 PARIS, BIBLIOTHÈQUE NATIONALE DE FRANCE, ESTAMPES ET PHOTOGRAPHIE, 4-PD-79

Grand Tour was to take on an influential role in British cultural affairs through the promotion of archaeology and the sponsorship of artistic institutions. Elite sociability, of which fancy dressing was an integral part, complemented their collecting and patronage. "Masquerades and sexual liaisons revealed the man of leisure," as their historian explains. ${ }^{41}$ But cross-cultural fancy dressing was not restricted to nobility; it became a highly popular activity in London.

Turkish masquerades abounded in eighteenthcentury France too. Ottoman disguises paradoxically served to publicly assert the power of the nation, or that of individuals. ${ }^{42} \mathrm{~A}$ stunning pub- lic success was the parade organised in 1748 by students of the French Academy in Rome on the occasion of the carnival. The procession comprised thirty-two persons on litters or horseback wearing elaborate Turkish attire that minutely reproduced the typical male and female figures found in costume books, such as the Recueil Ferriol, the feminine types being performed by male students in drag. The spectacle was so applauded that it was commemorated by a volume of watercolour engravings under the title La Caravane du Sultan à la Mecque ${ }^{43}$ some of which were in turn copied by later works. (Fig. 147) The whole point of

43 Joseph-Marie Vien, La Caravane du Sultan à la Mecque: mascarade turque faite à Rome par Messieurs les pensionnaires de l'Académie de France et leurs amis au carnaval de l'année 1748 (Paris: Basan et Poignant), 1748. 
the staging was to celebrate French wit - and the abilities of the young artists of the fashionable genre. Another, quite distinct, famous instance is Madame de Pompadour depicted as La Sultane by Carl van Loo around 175 o for a panel in her Turkish boudoir, a "self commentary in masquerade form" meant to consolidate her position at court, after having lost the King's favours. ${ }^{44}$

Turkish disguise continued to prosper in nineteenth-century France. A recorded instance is the public "grand oriental ball" organised in Paris on the occasion of the 1841 carnival. ${ }^{45}$ The new century, however, sanctioned a change in style. Sartorial turquerie was now competing with accoutrements from other parts of the Islamic world. Much commented upon in the press were the costume balls given at the Pavillon de Marsan in Paris by a son of the King, the young Duke of Orléans, in the 184 Os. At the reception held on 5 February 1842 , a number of artists wore diverse Eastern uniforms, from the attire of a "Mughal King," down to that of a "Tunisian leader," a "Muslim officer from the Russian Imperial guard" (a Tatar?) and a "Bedouin chief." Painters Adrien Dauzats and Amaury-Duval were dressed as Arnauts [from the Albanian Arnaut and Greek Arnaoutis, designating a member of the Albanian militia], while Horace Vernet had adopted the "burnous, arms, camel reins and complexion of an Arab sheikh,"46 a reminiscence of either of his sojourns in Algeria since $1833,{ }^{47}$ or most likely his encounter with a Bedouin camel guide during his Near Eastern tour in 1839-40, as I suggest below. It was "universal history through costume," ${ }^{\prime 4}$ as a newspaper put it. At another time, the Duc himself had appeared in the uniform of a Spahi officer [from the Ottoman Turkish sipāhi for cavalrymen, based on the Persian sepāhi for

44 Perrin Stein, "Madame de Pompadour and the Harem Imagery at Bellevue," La Gazette des beaux-arts 123 (1994): 29-44.

45 "Le grand bal oriental," La Caricature, 7 March 1841.

46 Le Moniteur universel, 9 February 1842, no. 40, 259-6o.

47 On Vernet's extensive travelling in Algeria and his Algerian paintings, see Nicolas Schaub, Représenter l'Algérie. Images et conquête au XIX $X^{e}$ siècle (Paris: Comité des travaux historiques et scientifiques, 2015). horseman], an autochthonous cavalry corps organised in 1834 within the French occupation army in Algeria. ${ }^{49}$ Worthy of note is the military character of the disguises, and the shift to Balkan and North African garment when it came to "Oriental" attire. The turn sanctioned both the rise of Independent Greece (as symbolised by the Arnaut) and of colonial Algeria (the Spahi) in France's collective imagination. At the carnival of March 1851 in Rome, architect Alfred Normand and a couple of other fellows of the Académie de France appeared in "Arab costume," which they explained as representing that of a "Moor from Algiers."

Bal travesti chez le baron Lycklama (1874) by Dutch artist Peter Tetar van Elven further confirms the continuous diversification of "Arab disguise." (Fig. 148) The small canvas depicts a carnival reception organised at Villa Escarras in Cannes, the retreat of Dutch collector Baron Lycklama (mentioned in Chapter 1). Half a dozen turbaned heads are noticeable. The local press provides more detailed information. ${ }^{51}$ The reunion had taken place on 16 February 1874 and had gathered about 200 attendees, most wearing costumes from the Renaissance or the reign of Louis XV. In Arab guise was one M. Tève as "Arab Algerian" (possibly the figure at the left end of the painting). Lycklama's private secretary, Ernest Massenot, donned an "accurate replica" of the garment of a

49 Eugène Lami, Le Duc d'Orléans en costume oriental, s.d., in Paul-André Lemoisne, L'Oeuvre d'Eugène Lami, Essai d'un catalogue raisonné (Paris, 1914), 253, no. 1105; sale Une collection pour l'histoire, Sotheby's Paris, 29-3o September 2015, lot 27.

$5^{\circ}$ Letter of Alfred Normand to his parents, 14 March 1851 , quoted in Laure Ducos, "Alfred Normand (1822-1909) ou les leçons de Rome" (PhD diss., Tours University, 2013), 205. "Je m'étais fait un costume arabe, celui d'un maure d'Alger. J'avais de grandes guêtres rouges jusqu'aux genoux, des souliers jaunes, le pantalon turc; un gilet de soie jaune à raies, une chemise à manches. Un turban en soie rouge et jaune et sur les épaules un burnous noir ... Il paraît que j'étais pas mal et que je ressemblais assez agréablement à un Arabe; 4 April 1851: le costume n'est pas revenu fort cher, $25 \mathrm{f}$ environ." Watercolour at Musée des Arts décoratifs, gift by Jacques Foucart, 1979. Sunday 21 February 1874, no. 71, 1-2. 


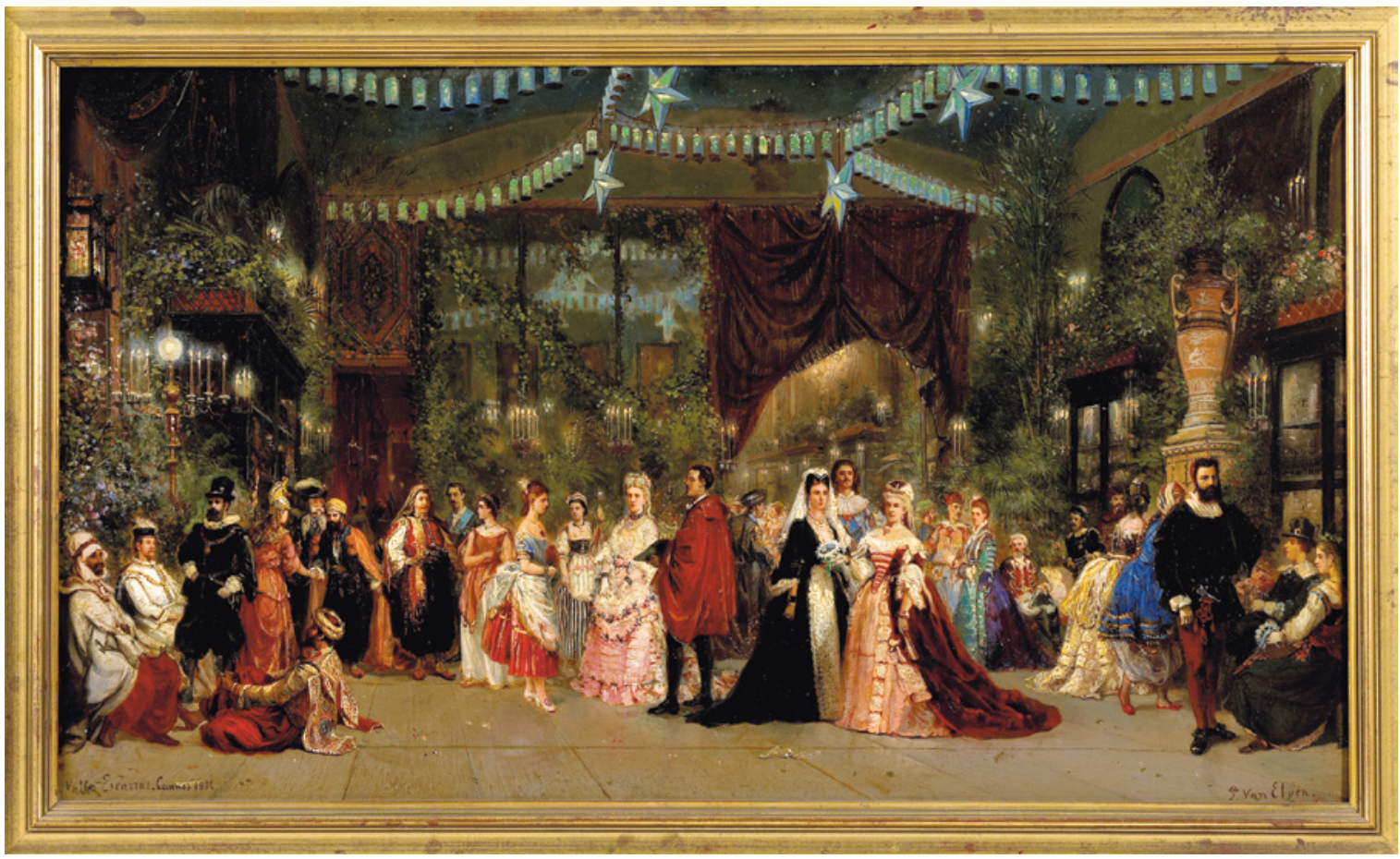

FIGURE 148 Peter Tetar van Elven, Bal travesti chez le baron Lycklama, 1874. Costume ball at Lycklama's villa in Cannes. From left to right: M. Tève as Algerian Arab, M. Massenot as Lebanese emir, M. Hennessy as a caliph and Baron Lycklama in mixed garb. Oil on canvas. $48 \times 81 \mathrm{~cm}$ CANNES, MUSÉE DE LA CASTRE, INV. 2005.0.346

Lebanese chief (the person sitting on the floor in front of Tève?). ${ }^{52}$ One M. Hennescy [Hennessy?] dressed as a "khalife" (in a long black robe beneath a red cape?) while a Miss Mulholland was in "Arab apparel" (a female cobalt blue dress over large pants is visible on the right side of the painting, behind the man in black and red). According to the report, the host wore the rich garb of a dignitary from Baghdad, selected among the many garments acquired during his Middle Eastern travels. A "grand Arab costume" from Baghdad does figure in the inventory of Lycklama's collections; it was made of a kaftan with short sleeves, a waistcoat (șudairiyya), and large trousers with waistband (dikka), all embellished with golden embroideries

52 József Borsos, Emir of Lebanon, 1843 (Budapest, Hungarian National Gallery, 2003.3) represents an Austrian aristocrat (count Edmond Zichy) in similar disguise. made by Baghdadi "Arab andJewish" [sic] women. ${ }^{53}$ Lycklama had himself portrayed wearing similar apparel a few years later. ${ }^{54}$ It is not however the dress he dons in Tetar van Elven's canvas. For the sake of easiness, one can venture that the artist had drawn it from a previous portrait, ${ }^{55}$ made after a photograph, which represented Lycklama in "Albanian dress," with Cairene architecture in the background (possibly a montage). (Fig. 149) Tetar van Elven had used the upper part of the picture to model Lycklama's posture and accoutrement,

53 No. 618 in Ernest Massenot, Musée de M. le chevalier T. M. Lycklama à Nijeholt: notice descriptive provisoire (2d ed.) (Brussels: P.-J. Leemans et Vanderendonck, 1871), 5 o.

54 Eugène Dretch (?), Tinco Martinus Lycklama à Nijeholt, 1878 (Cannes, Musée de la Castre, inv. 20o6.o.91). The painting is attributed to an artist that does not appear in any database; his name is probably miswritten.

55 Émile Vernet-Lecomte, Le Baron Lycklama en costume albanais, 1869 (Cannes, Musée de la Castre, 2005.0.350). 


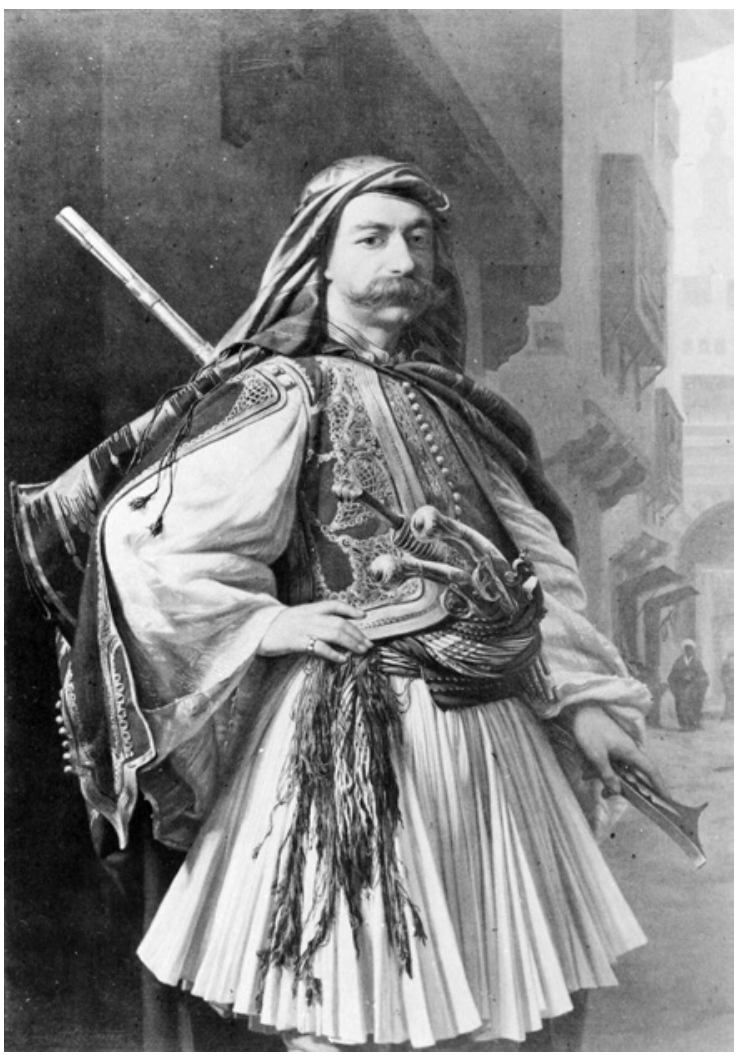

FIGURE 149 Robert Jefferson Bingham, Portret van Jhr. Tinco Martinus Lycklama à Nijeholt, 1869 . Portrait of Baron Lycklama in Albanian costume. Dimensions not provided LEEUWARDEN, FRIES MUSEUM, COLLECTION KONINKLIJK FRIES GENOOTSCHAPINV. PP1319A-01

leaving out the wide fustanella, the typical white pleated kilt worn by men in the Balkans, and replacing it with baggy trousers. Paintings are artifices after all.

\subsection{Ambivalent Trophies of Travel}

Bringing back full outfits from the Middle East was a common activity of early touring. Massenot had acquired his Lebanese disguise worn at Lycklama's party from a recent trip to the region. ${ }^{56}$ Lycklama himself acquired many items of clothing during his regular trips to Central Asia and the Near East in the 186 os and 1870 s. His attention to costume

56 "Bal costumé de la villa Escarras," Les Échos de Cannes, 21 February 1874, no. 71, 1-2. is a salient trait of his travelogue. He saw garments as specimens of a country's industry, ${ }^{57}$ and spared no effort in describing the wealth of costumes encountered on the road. While he doesn't disclose in which garb he travelled (his Albanian guise?), he narrates one special occasion in which he robed himself in his "grand Arab costume" from Baghdad. It was at the request of his host in Kermanshah (Iranian Kurdistan). The eldest son of the Qajar governor of the province, Prince Ali Quli Mirza Sarim ud-Daula (d. 1872), was a keen amateur photographer, who possessed the latest British and French equipment, and processed his plates himself. He wanted a picture of Lycklama in dignified attire for his albums. Two poses were sufficient to attain a result that pleased him. The Dutch traveller was offered a copy as a souvenir, among other photographs of the family and prestigious guests of the Qajar Prince. ${ }^{58}$ In this instance, cross-cultural dressing was a courtesy, inscribed in decorum, amiability and ... technology.

Sartorial souvenirs seemed to be meant primarily for portraiture, rather than wear. The fate of Lord Byron's Albanian clothes is significant in this respect. The British poet is known to have indulged in Ottoman disguise from a young age. While on a Mediterranean Grand Tour, he had acquired in 1809 some magnificent "Albanian costumes" for fifty pounds each. In 1813, he had his portrait taken while wearing one of them. The canvas was a success and was reproduced many times in oil and engraving. ${ }^{59}$ But he never wore the garb again: it reminded [him] “of one or two things I don't wish to remember," as he wrote to a friend shortly after sitting for the artist. ${ }^{60}$ This is clear confirmation,

57 Tinco Martinus Lycklama à Nijeholt, Voyage en Russie, au Caucase et en Perse, dans la Mésopotamie, le Kurdistan, la Syrie, la Palestine et la Turquie exécuté pendant les années 1866, 1867 et 1868 (Paris: Arthus Bertrand, 1872-75), III: 479 .

58 Lycklama, Voyage en Russie, III: 479.

59 Jennifer M. Scarce, "Lord Byron (1788-1824) in Albanian Dress: A Sartorial Response to the Ottoman Empire," Ars Orientalis 47 (2017): 158-77.

6o Leslie Alexis Marchand, Wedlock's the Devil: Byron's Letters and Journals (London: John Murray, 1975), 4: 113, quoted in Scarce, "Lord Byron," 161. 
if there was ever one, of the emotional power of clothes.

The Albanian dress became a prime visual symbol of Philhellenism in the $1820{ }^{61}$ It came to embody other meanings over the century. The guise, and by extension the people who donned it, referred to distinct groups. The noun initially alluded to populations from the Balkan Peninsula dispersed across the region, some having settled in present northern Greece and Macedonia; it went on to designate the special troops that Albanians formed within the Ottoman army. Their courage was legendary. Thousands of them were called to Egypt to fight the French occupation in 17981801, and many continued serving Mehmed Ali, the new governor, himself of Macedonian origin, afterwards. ${ }^{62}$ Albanians were reputed to be "quick and fiery, impetuous in anger, addicted to insubordination, and distinguished for contempt of authority."63 With the continuous military reorganisations prompted by the Porte and the need to reassert Ottoman power in Egypt, the disciplining of turbulent corps such as the Albanians, the Mamluks and the Janissaries became paramount. ${ }^{64}$ Such rearrangement eventually led to their disappearance (as per the massacre of Egyptian Mamluks in 1811) or their gradual return to civil life (the Ottoman Janissaries after 1827). In Cairo and Istanbul, Arnauts and Janissaries became mercenaries in the employ of embassies and private families alike as guards, footmen, or couriers. (Fig. 150 and 151) To complicate matters further, the fustanella and accompanying embroidered jackets were adopted following Independence by the nascent Greek army. It became the official court dress in 1835 , and ultimately the Greek national

61 Nina Athanassoglou-Kallmyer, "Of Suliots, Arnauts, Albanians and Eugène Delacroix," The Burlington Magazine 125, no. 965 (Aug 1983): 486-91.

62 [Émile] $\mathrm{P}$ [risse] and $\mathrm{P}$ [ierre] $\mathrm{N}$ [icolas] $\mathrm{H}$ [amont], L'Égypte sous la domination de Méhémet-Ali, L'Univers pittoresque 45 (Paris: Firmin-Didot Frères, 1848) III: 2-3.

63 Oriental Album, 1-2, pl. 2.

64 Khaled Fahmy, All the Pasha's Men: Mehmed Ali, His Army and the Making of Modern Egypt (Cairo: AUC Press, 1997), 79-86. costume. ${ }^{65}$ The meaning of Albanian attire had thus shifted over a few decades, inducing confusion for outsiders. 66

Nevertheless, travellers continued to be portrayed in "Albanese guise," once in the region. A later example, a few years later than Lycklama's portrait in Albanese suit, features Lockwood de Forest. (Fig. 152) His photograph in carte-devisite format is unlabelled, but can be paired with a parallel disguised portrait bearing identical location, as evidenced by the floor's tiles. ${ }^{67}$ The latter was authored by photographers P. Sotiropoulos and I. Mantzakos in Athens. (Fig. 153) De Forest's portrait can be dated to late spring 1876 when he was touring the region. ${ }^{68}$ The other portrait possibly depicts his travel companion then, his cousin George Deforest Lord. Both men are robed in "Albanian guise," now identified as "Greek", but both sets of attire are specific, which suggests personal possession, rather than props provided at the studio. The non-pristine condition of the clothing supports the former hypothesis. Both men carry a different rifle and a number of other arms, equally specific. Were these the outfits in which they had been travelling across the

65 Scarce, "Lord Byron."

66 For the ambiguities of the visual representation of Albanian attire in post-revolutionary France, see Elisabeth A. Fraser, Mediterranean Encounters, Artists Between Europe and the Ottoman Empire, 1774-1839 (University Park: The Pennsylvania State University Press, 2017), chapter 5 passim.

67 Washington, DC, Smithsonian Institution, Archives of American Art, Lockwood de Forest papers, Box 3, folder 25 , f. 1 and Box 3 , folder 30 , f. $2-3$.

68 Three stays by de Forest in Athens are recorded, one in 1869 when he was still a young man (nineteen years old), a three-week sojourn in late spring 1876 , on his way back from a large tour of Egypt, Syria and Palestine, and a longer residence during the winter of 1878; the facial features of the portrayed de Forest correspond with a person in his late twenties rather than a barely twenty years old young man, while the short sleeves of his costume suggest spring rather than winter time, which would better match the 1876 stay, than the one taking place eighteen months later; Roberta Ann Mayer, "Understanding the Mistri: The Arts and Crafts of Lockwood de Forest (1850-1932)" (Ph.D diss., University of Delaware, 200o), chapter 3 passim. 


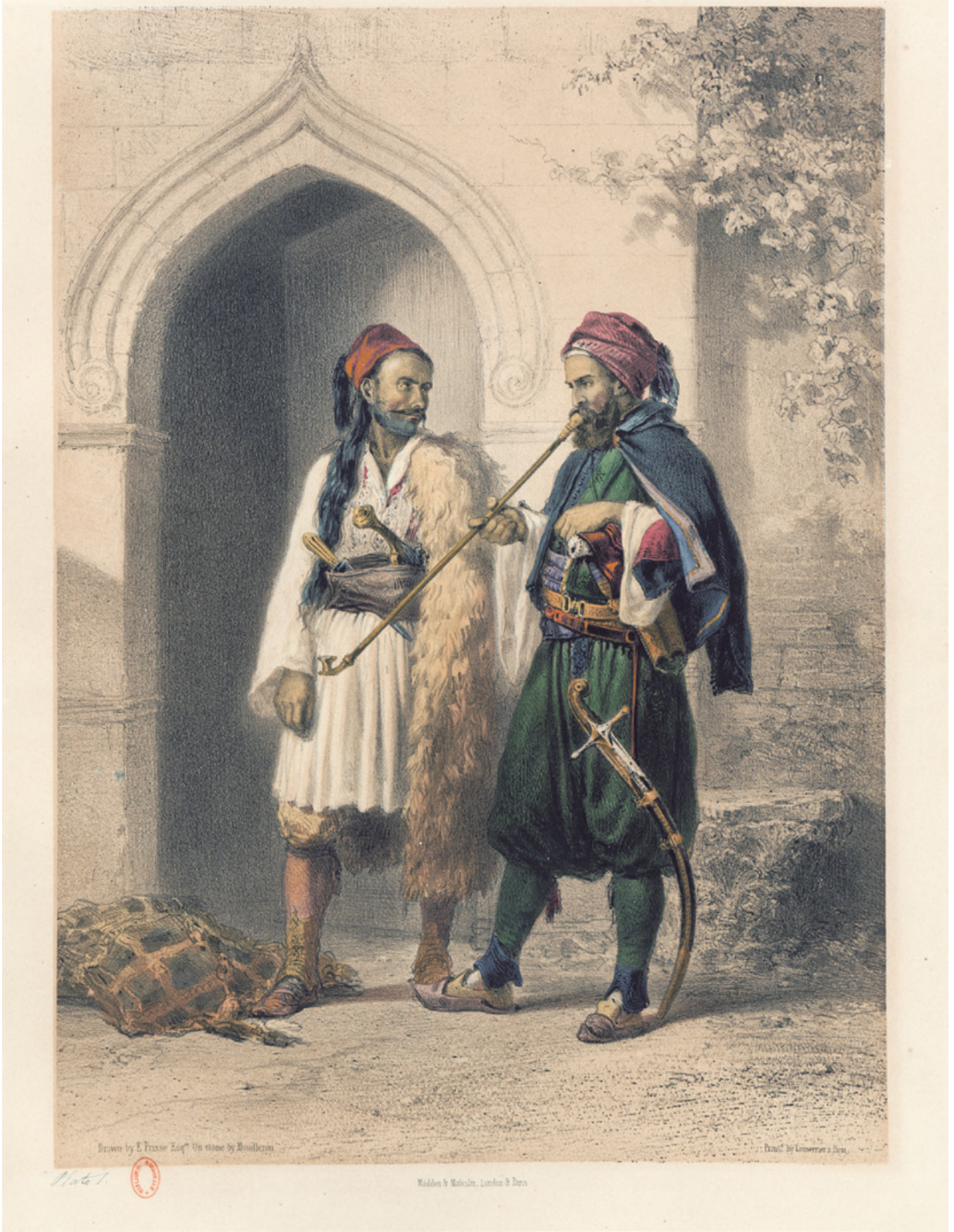

FIgURE 150 Émile Prisse d'Avennes, Arnaout and Osmanli [soldiers] in Alexandria. Both figures are possibly Europeans in Middle Eastern guise. Chromolithograph ORIENTAL ALBUM, CHARACTERS, COSTUMES AND MODES OF LIFE IN THE VALLEY OF THE NILE, ILLUSTRATED FROM DESIGNS TAKEN ON THE SPOT BY E. PRISSE, 1848: PL. 1 


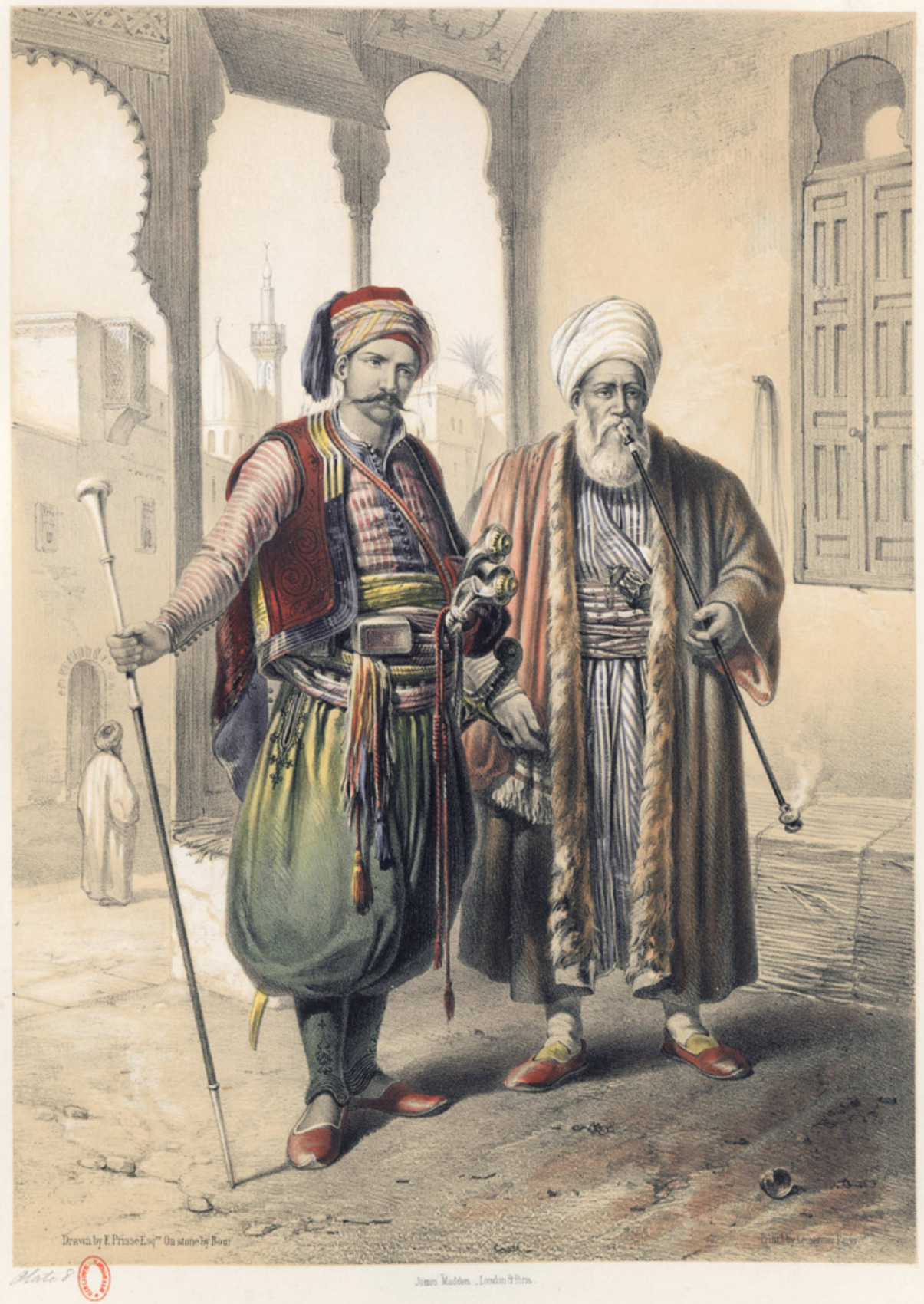

FIGURE 151 Émile Prisse d'Avennes, Janissary and merchant. Chromolithograph ORIENTAL ALBUM, CHARACTERS, COSTUMES AND MODES OF LIFE IN THE VALLEY OF THE NILE, ILLUSTRATED FROM DESIGNS TAKEN ON THE SPOT BY E. PRISSE, 1848: PL. 8 


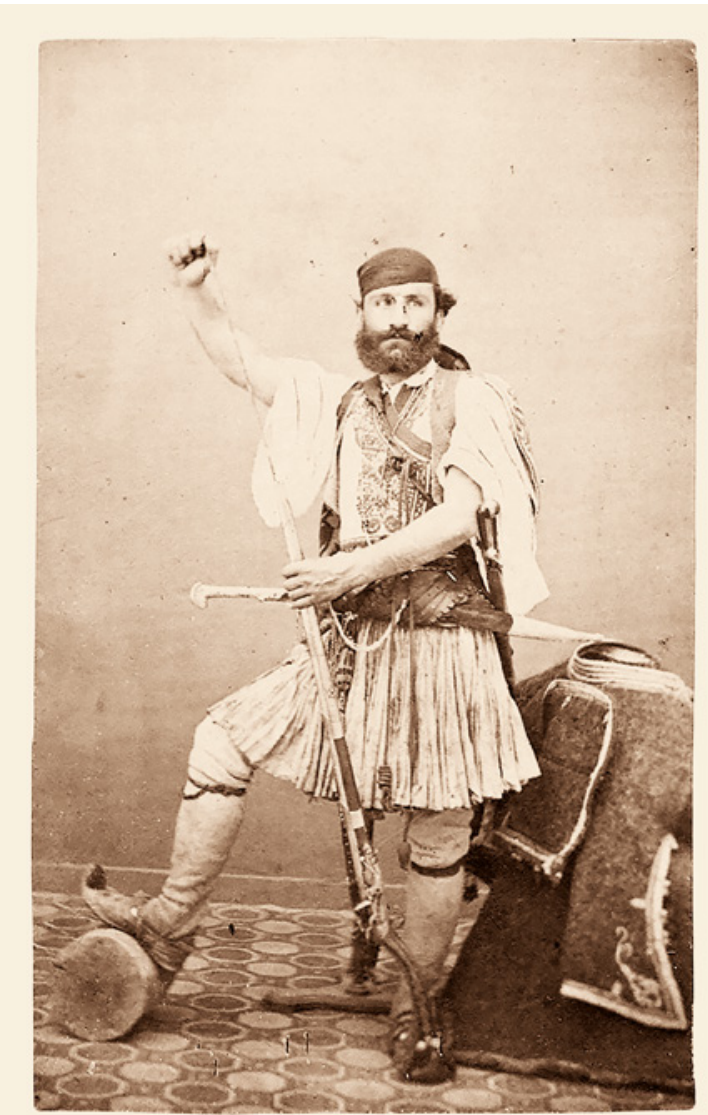

FIGURE 152 P. Sotiropoulos and I. Mantzakos (attr.), Lockwood de Forest in Greek attire [May or June 1876]. Albumen print. $13 \times 8 \mathrm{~cm}$ WASHINGTON DC, SMITHSONIAN INSTITUTION, ARCHIVES OF AMERICAN ART, LOCKWOOD DE FOREST PAPERS, BOX 3, FOLDER 25, F. 1

region out of convenience, as Henri Moser did in his fur-lined kaftan? Did they solely serve for a photographic session in order to authenticate their travel experience? Were they intended as a tribute to Greek folk culture? Donning exotic costumes was in many instances an act of homage to otherness. ${ }^{69}$ Were the two comrades just having fun? Expressing manly bravery? It is hard to ascertain definitively, in the absence of direct testimony. Set in conjunction with Lycklama's

69 Castle, Masquerade and Civilization, 6o-1.

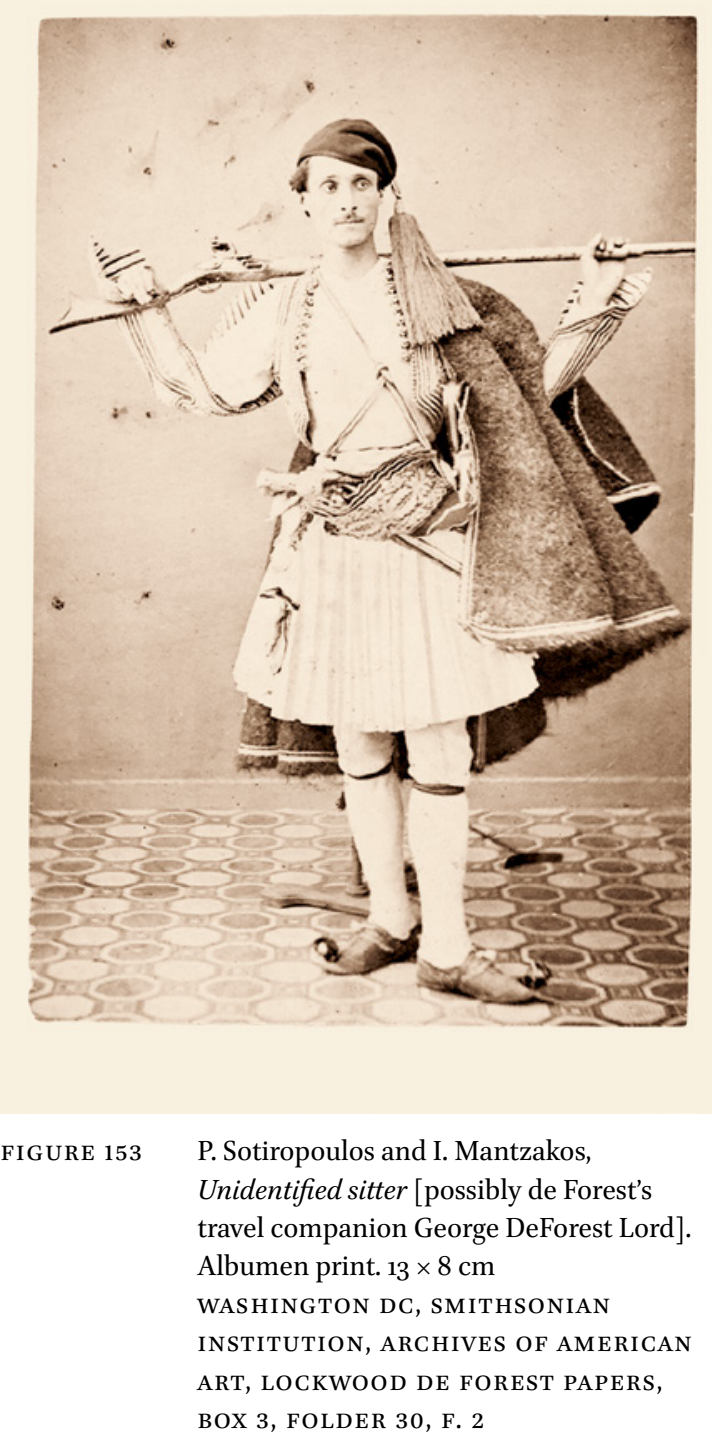

portrait, the photographs point to a shared gusto for Albanian/Greek guise by collectors wandering in the region in the 186 os and 1870 , in search of a vanishing past through art. In other words, they highlight a fashion. In a Far Eastern context, such cross-dressing has been characterised as a kind of "alternative consumerism," symbolic of the performance of modernity. ${ }^{70}$ In any case, most analysts of cultural cross-dressing referred to so far concur

70 Christine M.E. Guth, "Charles Longfellow and Okakura Kakuzō: Cultural cross-dressing in the colonial context," Positions 8, no. 3 (200o): 6o5-36. 
that these performances were not stages in a process of cultural conversion, but circumstantial fantasies, that we can't help seeing today as a bit ridiculous ...

\section{2}

\section{Dressing Native in Nineteenth-Century Egypt and Back Home}

Looking at cultural cross-dressing in the specific case of Egypt brings further insights into the why and how of the phenomenon. It highlights various perceptions. It outlines stories of necessity, and in contrast, self-fashioning. It engaged varied forms of impersonation in gesture and attitude. A systematic survey across the available evidence induced John Rodenbeck to conclude that bravura and seduction had their say too. ${ }^{71}$ But disguise was not only a matter of individuality; local circumstances shaped it as well. They determined whether it was recommendable or not to wear a local costume and they defined the type of outfit desirable. Different modes of engagement with Egyptian culture ensued. In other words, dressing native was inscribed into intercultural relations, and in return was shaped by the outcome of that interplay. As we shall see, the phenomenon meant quite different things in Egypt at the dawn of the nineteenth century, and over its course.

\subsection{From Necessity to Initiative}

Sources concur that the shift from necessity to initiative can be dated to the 183 os. A commonly quoted brief from an official French newspaper stated in 1832:

Les routes sont parfaitement sûres en Égypte; on peut même les parcourir en vêtements européens et sans le moindre danger d'ici jusqu'au Sennaar. ${ }^{72}$

\footnotetext{
$71 \quad$ Rodenbeck, "Dressing native."

72 "Nouvelles extérieures," Le Moniteur Universel, 29 July 1832, 1522. "Roads are perfectly safe in Egypt; you can even travel on them in European cloths and without the slightest danger until Senaar."
}

Prior to that date, European travellers shared the belief that wearing local clothes was a requisite to safety, and as they wrote, commanded respect. No one expressed it more clearly than British collector Henry Westcar (1798-1868) while in Cairo in 1824:

Under the auspices of [Osman effendi] ${ }^{73} \mathrm{I}$ became to appearance a Turk; my head shaved, a Mameluk turban and a proud look. I walked along the streets and the first day I found the difference of the change. When dressed in Frank clothes, every ragged Arab that passed would run against you, and the soldiers elbow you and make you get out of their way. When, when [sic] I was a Turk, with my pipe bearer before me, all get out of the way, and the Arabs who were sitting down, got up as I passed and saluted me. Then I was a great man and it is not the first time that I have found persons judging of a person more by the cut of his coat than his mind. ${ }^{74}$

Travelling with his father from Istanbul to Cairo in 1825 for archaeological purposes, French scholar Léon de Laborde (1807-1869) confirmed that they had been convinced to the "necessity of this masquerade" for their own security. He acknowledged collateral benefits. He considered the "Turkish costume" as healthier, for it was more ample and comfortable than European garments; turban and sash prevented catching the usual diseases contracted by Europeans in the region as they kept head and stomach warm. ${ }^{75}$

A visual testimony of their accoutrements is provided in their travel account. (Fig. 154) Two different types of Turkish costumes are illustrated.

73 A Scottish renegade living in Cairo since 1807 , see Jason Thompson, "Osman Effendi: A Scottish convert to Islam in early nineteenth-century Egypt," Journal of World History v, no. 1 (Spring 1994): 99-123.

74 Quoted in Heike C. Schmidt, Westcar on the Nile, A Journey through Egypt in the 1820 (Wiesbaden: Reichert Verlag, 2011), 149.

75 Léon de Laborde, Voyage de l'Asie mineure par Mrs Alexandre de Laborde, Becker, Hall et Léon de Laborde, rédigé et publié par Léon de Laborde (Paris: Firmin Didot, 1838), 27-8. 


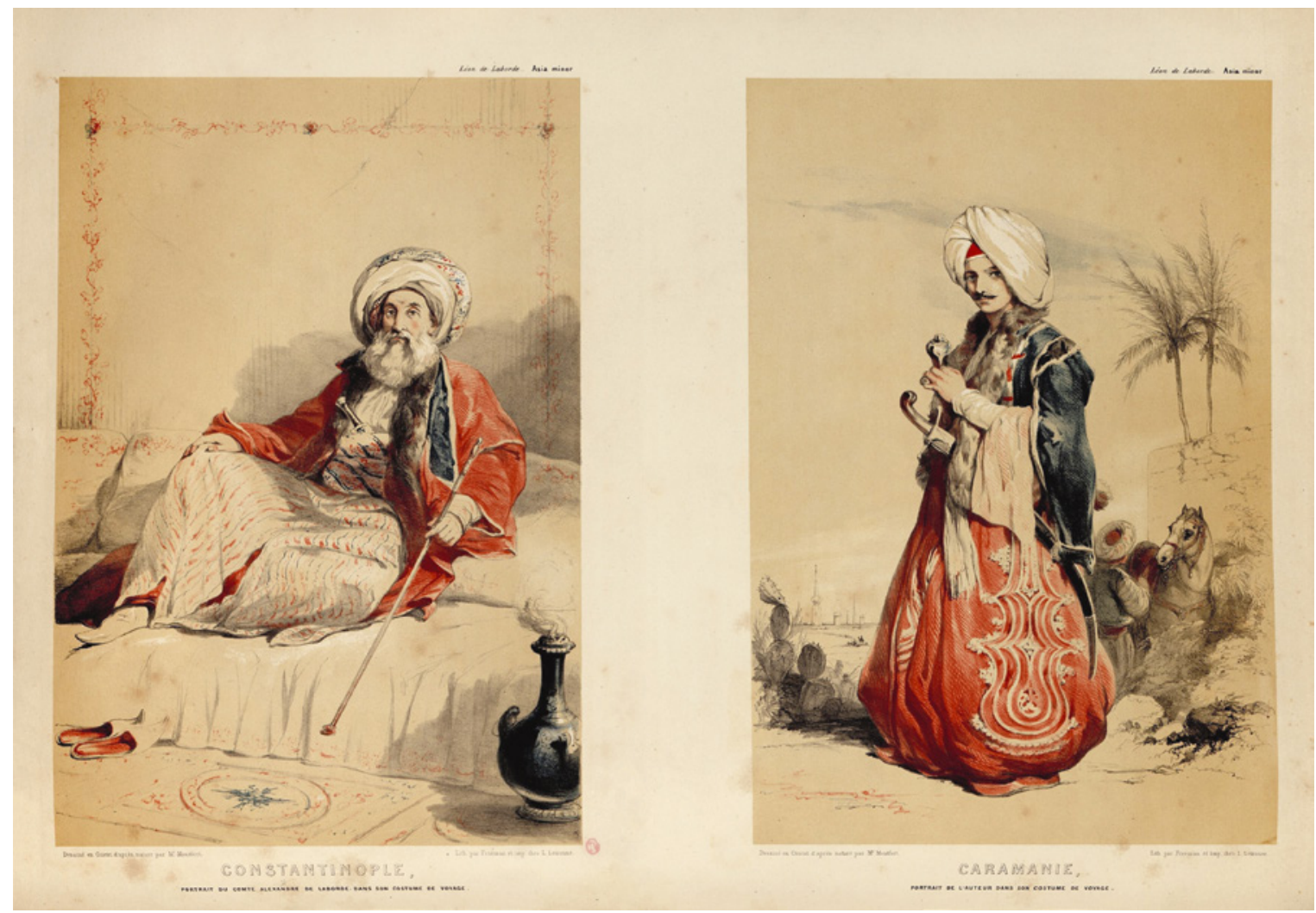

FIGURE 154 Antoine de Monfort, Portraits du comte Alexandre de Laborde et de son fils Léon dans leur costume de voyage, 1825. Chromolithograph

LÉON DE LABORDE, VOYAGE DE L'ASIE MINEURE, 1825: UNUM. PLATE

The father wore a "costume à la longue," in his son's words, a phrase encountered in other travelogues. The outfit was composed of long robes worn over the typical red şalvar [shalwar] and under a furtrimmed overcoat. The garb was a formal one, necessitated by the welcoming ceremonies that Alexandre de Laborde had to attend throughout the trip. The son wore an outfit that he pretended was more fitted to horse riding and his digging activities, with long baggy trousers and short waistcoat over an inner entari [Turkish for gown], a costume closely resembling that of the military cast, as worn by Mamluks and Janissaries. The two men were heavily armed, although acknowledging that gifts facilitated travel more effectively than any "true arsenal."

French artist Horace Vernet also chose the costume à la longue, when travelling in Egypt in 183940. (Fig. 155) In the account of the tour, his student and travelling companion Frédéric Goupil-Fesquet further voiced the benefits of disguise for artists. In his words, dressing native should not pass for "puerile disguise," an indirect admission that a measure of childishness loomed somehow in the background. Adopting local clothing was a matter of adaptation to the weather, an issue of hygiene, and lastly a means to supposedly ensure invisibility in order to sketch freely in streets and mosques:

En effet, les habits du pays sont beaucoup plus commodes que les nôtres à cause de leur ampleur. De plus, le dessin étant inconnu ou plutôt défendu chez les musulmans, nous pourrons nous livrer à la récolte indispensable des croquis, en tout lieu, sans être remarqués sous le vêtement musulman, et il nous sera aisé de pénétrer dans les mosquées en ôtant nos babouches; grâce à ces 


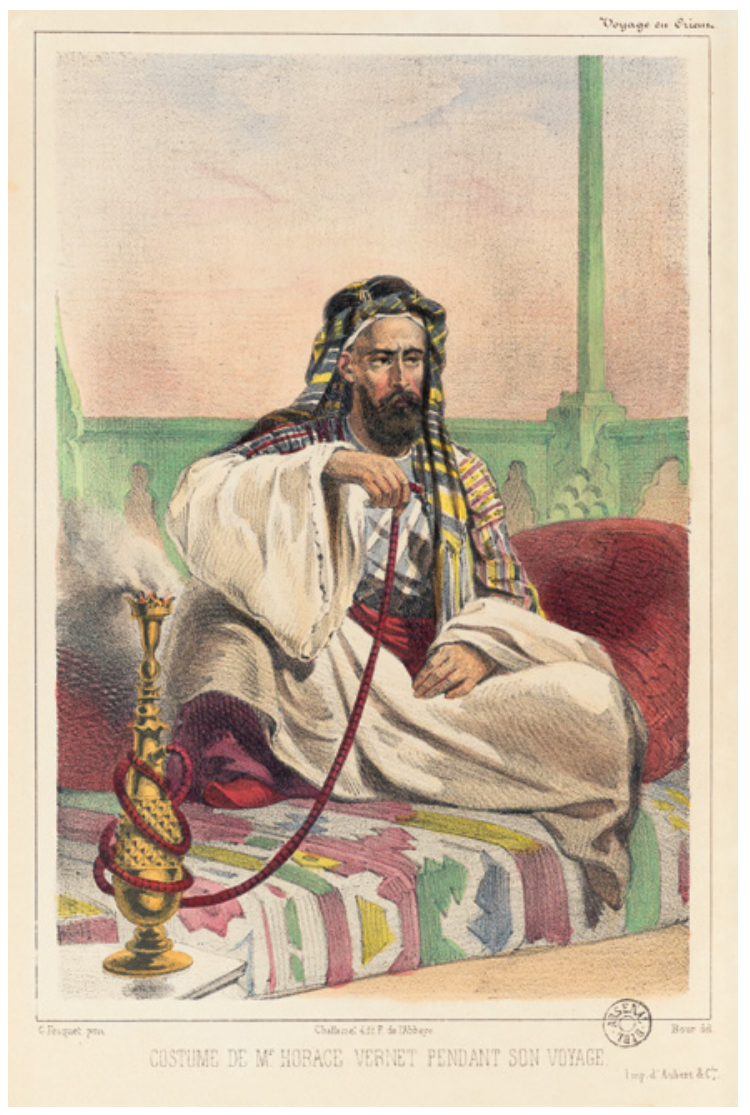

FIGURE 155 Frédéric Goupil-Fesquet, Costume de Mr Horace Vernet pendant son voyage, 1839. Chromolithograph FRÉDÉRIC GOUPIL-FESQUET, VOYAGE D'HORACE VERNET EN ORIENT, 1840: AFTER 117

précautions nous serons confondus avec les fidèles. L'habit est collant, boutonné et agrafé étroitement aux manches et aux jambes contre les incursions des insectes qu'on craint de nommer. Le soin de se raser la tête est une mesure de propreté qu'il serait ridicule de ne pas admettre. Les vêtements du pays ont été faits pour les exigences du climat. ${ }^{76}$

Frédéric Goupil-Fesquet, Voyage d'Horace Vernet en Orient (Paris: Challamel, 1843), 79. "Local clothes are actually much handier than ours because they are more ample. Besides, as drawing is unknown or rather forbidden by Muslims, we can sketch wherever needed without being noticed under our Muslim costume, and it will be easy to enter mosques by taking our slippers off; thanks to these precautions, we will be confused
Their "metamorphosis into Arabs" took place as soon as they set foot in Cairo. ${ }^{77}$ Goupil-Fesquet does not tell if the artifice was effective - in other instances, as to be seen below, it provided trouble rather than anonymity. That same year, the British artist David Roberts was informed by his Consul that in order to visit mosques in Cairo and make drawings, he had to assume the Turkish dress, ${ }^{78}$ which he did; he managed to secure the drawings he wanted under the disguise. French architect Pascal Coste had done the same twenty years earlier in order to carry out his own survey of Islamic architecture in Cairo. ${ }^{79} \mathrm{~A}$ tradition of disguise that facilitated entering mosques did exist.

The local costume that Europeans mainly donned in the following decades remained an adaptation of the Turkish military dress; it was also the common attire of the many Turkish merchants - or rather Osmanli, as they preferred to be named - operating in the country, according to unpublished notes drafted by Arabist Edward William Lane in $1834{ }^{80}$ The common outfit underwent some changes with the "new order" promoted by Mehmed Ali (Nizâ̄m-ı Cedid in Ottoman Turkish). The main innovations of the Nizami uniform, or vêtement à la nizam in French sources, were that the baggy trousers were now tight from knee downwards and that a close-fitting vest had replaced the silk entari; the waistcoat eventually adopted the very name of the long shirt. ${ }^{81}$ In the

with believers. The garb is tight; it is buttoned narrowly to the sleeves and pants against insect incursion. The act of head shaving is a measure of cleanliness that it will be ridiculous to dismiss. The clothes of the country have been made for the requirements of its weather." [My translation].

77 Goupil-Fesquet, Voyage d'Horace Vernet, 45

78 Entry in his travel journal dated January 2, 1839, quoted in Scarce, "Lord Byron," 170.

79 Dominique Jacobi, ed., Pascal Coste, toutes les Égypte (Marseilles: Parenthèses, 1998).

8o Jason Thompson, "OF THE 'OSMA'NLEES, OR TURKS': An unpublished chapter from Edward William Lane's Manners and Customs of the Modern Egyptians," Turkish Studies Association Bulletin 19, no. 2 (Fall 1995): 19-39.

81 "L'uniforme des officiers du Nizam est en drap ponceau bleu de ciel; il consiste en une veste ou justaucorps appelé entéri, et un pantalon très large de la ceinture 


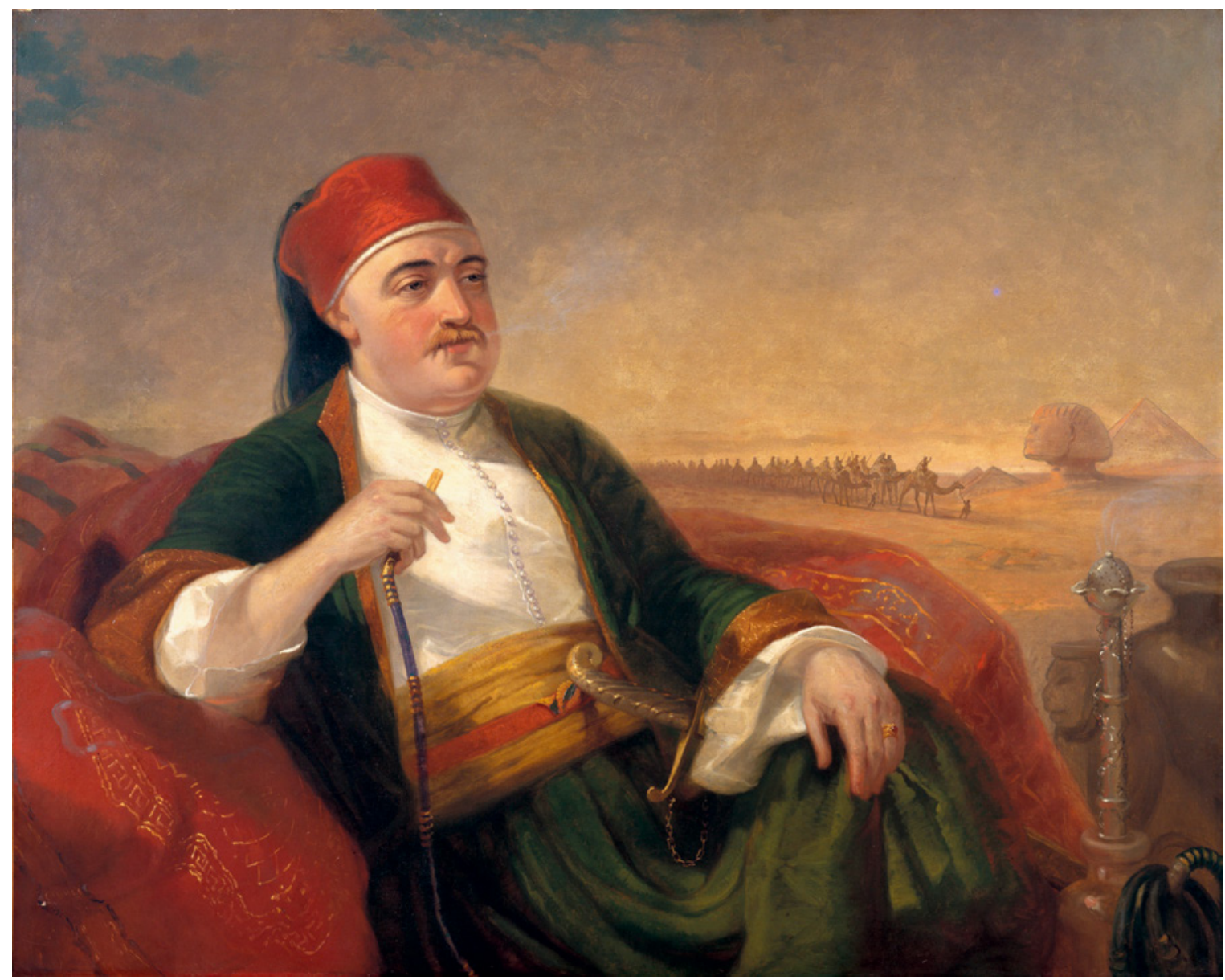

FIgURE 156 Thomas Hicks, [Posthumous] Portrait of Henry Abbott, 1863 (after a coloured pastel drawn by Andrew Morris in 1853). Oil on canvas. $101 \times 127.6 \mathrm{~cm}$

NEW YORK, BROOKLYN MUSEUM, GIFT OF THE NEW YORK HISTORICAL SOCIETY, 48.191

late 183 os, the tarbush or fez superseded the turban for the army and civil service alike, while the rest of society continued wearing the latter. The Turkish costume could otherwise be combined with a turbaned shawl over the fez. Weaponry and turban became exclusive of one another; people either wore one or the other. The traditional yellow inner slippers [ $\mathrm{mizz}$, a word of Turkish origin] were now covered by thick red pointed shoes, named markū $b .{ }^{82}$ Another turn was the adoption of dark colours: black, dark green or blue, whether

au jarret et collant comme une guêtre jusqu'à la cheville." P[risse] and $\mathrm{H}$ [amont], L'Égypte sous la domination de Méhémet-Ali, 133.

82 Rachel Arié, "Le costume en Égypte dans la première moitié du XIX ${ }^{\mathrm{e}}$ siècle," Revue des études islamiques XXXVI (1968): 201-13. for Nizami garb or not, in addition to the bright tones of previous Muslim attire. (Fig. 150)

The Nizami dress is the costume that the innumerable Europeans in the service of the Egyptian administration donned as an attribute of their function. Architect Pascal Coste, French doctor Antoine Clot-Bey, ${ }^{83}$ British physician Henry Abbott (Fig. 156), ${ }^{84}$ engineer Linant de

83 Clot-Bey recalls in his memoirs that his recruitment contract explicitly stated that he had to don the Nizami garb when requested to do so; one of his uniforms is kept in the Musée d'archéologie méditerranéenne in Marseilles (5514.2-5); Le Goût de l'Orient, Collections et collectionneurs de Provence, eds. Aurélie Bosc and Mireille Jacotin (Milan: Silvana Editoriale, 2013), 223.

84 Abbott's posthumous portrait was made after a coloured pastel authored by Andrew Morris in 


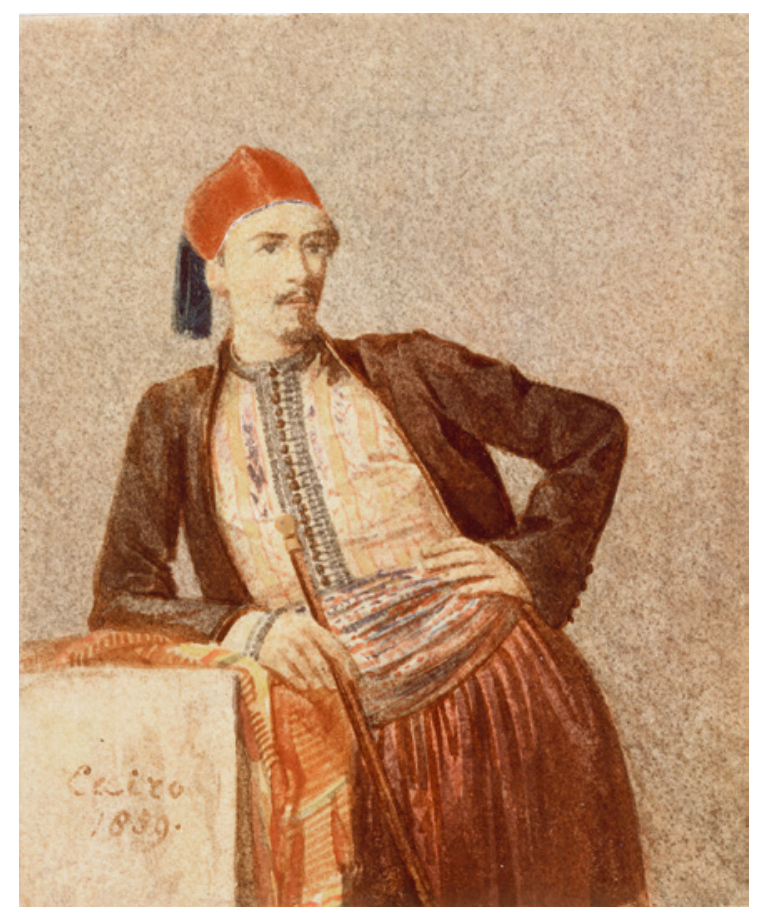

FIGURE 157 Édouard Jarrot, Portrait de Willem de Famars Testas, fait au Caire par Jarrot, notre photographe, en 1859. Photograph hand-coloured with watercolour, $8.4 \times 7 \mathrm{~cm}$ LEIDEN, NATIONAL MUSEUM OF ANTIQUities, ARCHIVES 19.6.3/1A

Bellefonds, Colonel Sève, and antiquarian Émile Prisse d'Avennes, to name but a few, have all been portrayed in this "Turkish costume," either in its everyday formula, or in its ceremonial variant. Lane himself, like many other European travellers or expatriates, dressed in Nizami garb, with a wound shawl over his fez. ${ }^{85}$ It was an experience worth recording visually.

Europeans continued donning the Nizami guise long after it had ceased being a requisite for safe travel. Willem de Famars Testas, who assisted Prisse d'Avennes in his late archaeological works,

1853, Andrew Oliver, American Travelers on the Nile: Early U.S. Visitors to Egypt, 1774-1839 (Cairo: AUC Press, 2015), 312.

85 Richard J. Lane, Portrait of Edward Lane, c. 1836 (Oxford University), reproduced in Jason Thompson, Edward William Lane (1801-1876), The Life of the Pioneering Egyptologist and Orientalist (Cairo: AUC Press, 2010), unum. plate after 534 . was portrayed wearing it in $1859 .{ }^{86}$ (Fig. 157) Later photographs show slight changes in the arrangement of the outfit, as illustrated by a group portrait shot in Alexandria in 1867. The carte-de-visite picture stages the famous American writer Mark Twain (standing on the right), with a fellow traveller and their dragoman (interpreter). (Fig. 158) Their adventures in Near Eastern lands inspired his Innocents Abroad, a humorous tale of the excursion written in press report prose. The suit of the seated figure has been preserved, offering insights on the colourfulness involved. It was made of broadcloth in a heavy camel colour, and complemented by a shawl of contrasting deep blue. The trousers were longer than the original Nizami ones, and boots had replaced the slippers. The style followed the new costume of Egyptian government's employees. ${ }^{87}$

This type of attire could be considered local, as it was worn by the ruling elite and government employees in Egypt, but it clearly distinguished travellers from the rest of the population, whose common garb was the costume à la longue, composed of a long vest of striped silk and cotton, also named a kaftan, over a linen shirt and drawers, completed in winter by a long cloth coat called a jubba. ${ }^{88}$ Blending in with the population was not exactly the point.

Yet travel could foster unforgettable interactions. Vernet held vivid memories of the Bedouin sheikh who guided him and his party from Cairo to the Holy Land in late autumn 1839. The man

86 Marteen Raven, "Extraits du journal égyptien de Willem de Famars Testas (1858-186o)," in Émile Prisse d'Avennes, un artiste-antiquaire en Égypte au XIX $X^{e}$ siècle, ed. M. Volait (Cairo: Publications de l'IfaO, 2013), 189-213 (fig. 3).

87 For an example, Elke Pflugradt-Abdel Aziz, "Julius Franz-Pasha's Die Baukunst des Islam (Islamic architecture) of 1887 as part of the Manual of Architecture," in Le Caire dessiné et photographié au $X I X^{e}$ siècle, ed. Mercedes Volait (Paris: Picard/Inha, 2013), fig. 1 [https://books.openedition.org/inha/4853? lang=fr], Accessed 13 March 2021.

88 Edward William Lane, Manners and Customs of the Modern Egyptians (London: J. M. Dent \& Sons, 1944/1908 edition), 30-1. 


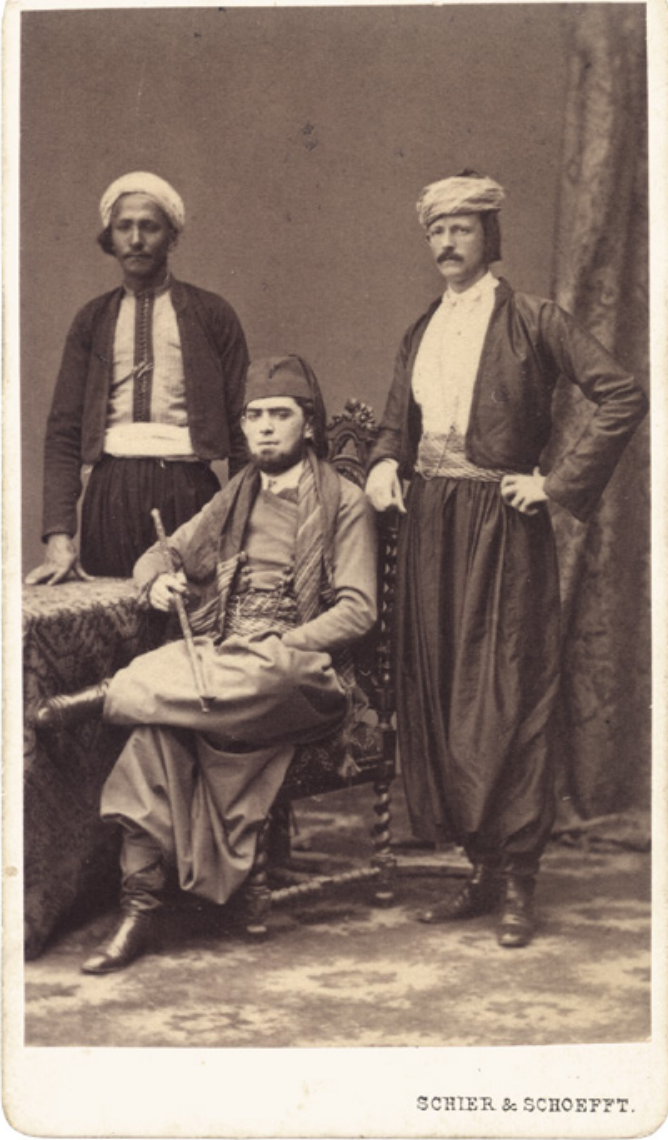

FIGURE 158 Schier and Schoefft, [Charles Langdon and Samuel Clemens, a.k.a Mark Twain, in neo-Nizami garb, in probable company of their dragoman], Alexandria, Egypt, Fall of 1867. Albumen print on board.

Carte-de-visite format

NEW YORK, ITHACA, CORNELL

UNIVERSITY, COLLEGE OF HUMAN ECOLOGY, DEPARTMENT OF FIBER SCIENCE AND APPAREL DESIGN, 2003.29.002

appears several times in his narrative of the ride, and in a letter to Antoine de Montfort. He is remembered as old Selim and was supposedly from a tribe in Mount Sinai. Sheikh Selim and two young companions had been recommended to Vernet by Linant de Bellefonds. They procured the nine camels plus donkey that were to transport Vernet, his student Frédéric Goupil-Fesquet, his nephew Charles Burton, a French servant, an
Egyptian cook, the dragoman Georges Khalil, and all their impedimenta, through the Eastern desert up to a certain point on the road to Jerusalem. Selim happened to be an astute guide, who knew how to navigate the caravan safely through "a sea of sand with his acumen as sole compass," even though he had not walked the route since the siege of St John of Acre in $1799 .{ }^{89}$ Selim possessed piercing sight and an acute ear, and he was also the proud owner of a rifle that he constantly inspected and manipulated.

Vernet was fascinated by the "expressive physiognomy" of Sheikh Selim. He was captivated by the colour of the skin, the white beard, fleshy lips, radiant eyes, bushy eyebrows and marked wrinkles. ${ }^{90}$ Between the two men tactility unfolded:

Il [Selim] nous fait toutes sortes de caresses; Vernet semble avoir la plus belle place dans son affection; il le cajole, le flatte de la main et prend de lui un soin tout particulier manifesté par mille attentions de tous genres. Il dit que Vernet a une vraie figure d'Arabe. ${ }^{91}$

Whether Vernet could pass for a true Arab is highly questionable; it was a courtesy from Selim to say so. But anyone having experienced desert travel in the region will not doubt the intensity of the affectionate gestures. The memorable connection between the two men survives in the unique canvas that Vernet derived from his entire

89 Letter to Antoine de Monfort, 11 September [sic for December] 1839: "Nous étions au milieu des tombeaux des califes, en face du désert, et n'ayant dans cette mer de sable d'autre boussole que l'intelligence de notre vieux scheik qui, depuis l'expédition des Français à St-Jean d'Acre, n'avait pas vu le pays que nous allions parcourir." Horace Vernet, "Des rapports qui existent entre le costume des anciens Hébreux et celui des Arabes modernes," L'Illustration, 12 February 1848, 370-72.

90 Goupil-Fesquet, Voyage, 131-32, 134 .

91 Goupil-Fesquet, Voyage, 137. "He [Selim] caresses us in every possible way; Vernet seems to have the best place in his affection; he is being cajoled, flattered by the hand, and taken care of with particular attention. He said that Vernet has a real Arab face." [My translation] 


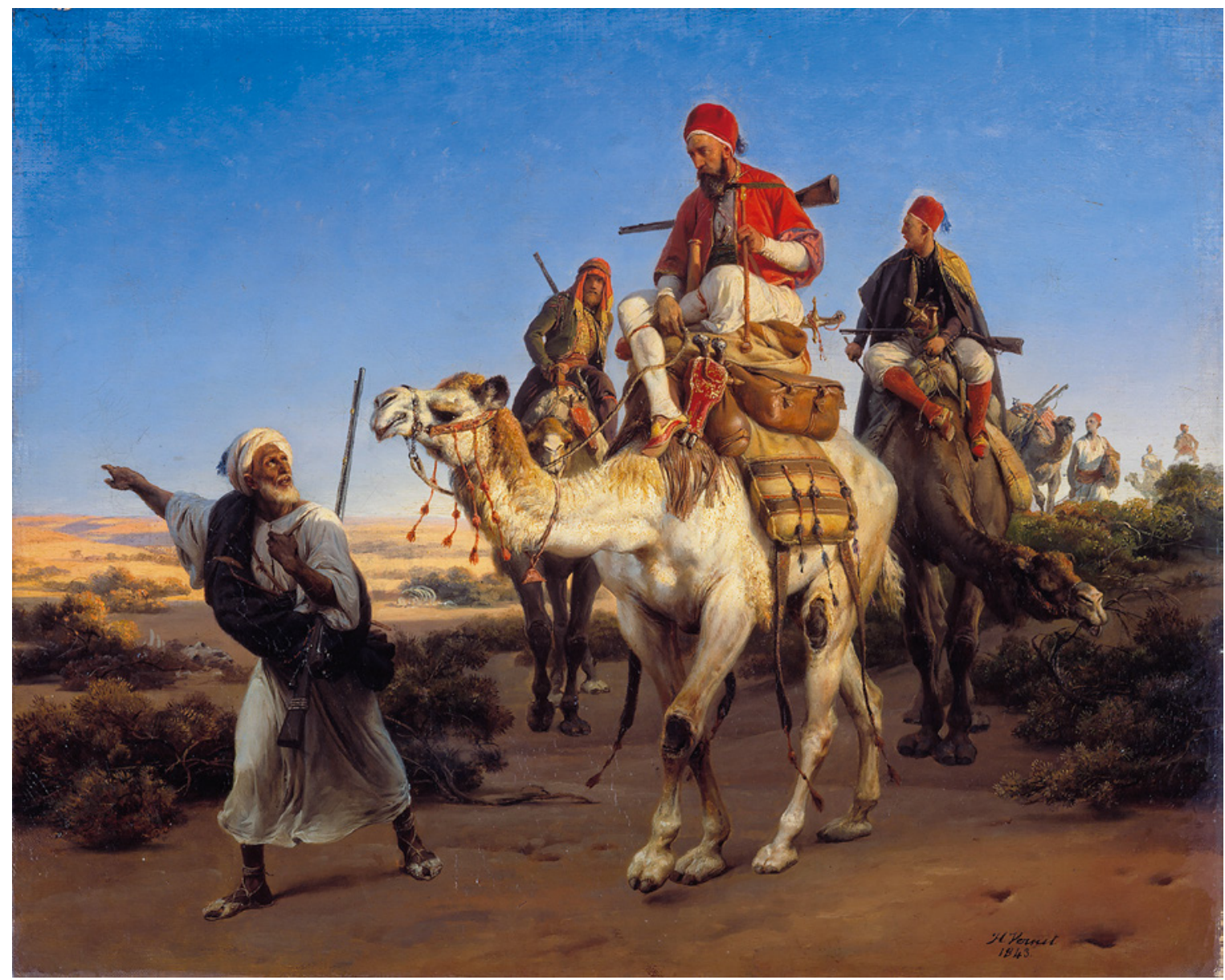

FIGURE 159 Horace Vernet, Voyage dans le désert [The Artist and his Companions Travelling in the Desert], 1843. Oil on canvas. $46.7 \times 57.7 \mathrm{~cm}$

LONDON, WALLACE COLLECTION, P584

journey in Egypt, Syria and Palestine. (Fig. 159) The small anecdotal piece was exhibited at the 1844 Salon in Paris under the title Voyage dans le désert. It was painted during Vernet's later stay in St Petersburg and finished on 26 November 1842; the "small unpretentious canvas, representing our caravan in the desert" was initially made by Vernet to evaluate the worth of his art in Russia. ${ }^{92}$ The piece represents the convoy after having parted with Linant de Bellefonds and American consul

92 Horace Vernet's letters to his wife dated 29 October and 26 November 1842, in Amédée Durande, Joseph, Carle et Horace Vernet: correspondance et biographies (Paris: J. Hetzel, 1864), 202, 215.
George Gliddon, who had joined the beginning of the ride but had then gone towards Suez. A highranking official in charge of Public Works in the administration of Mehmed Ali, Linant rode an elegant white camel that Vernet transposed as his own in the painting. Vernet also clothed himself in Nizami garb - that is in Linant's uniform - rather than in the costume à la longue that he is known to have worn throughout the trip. Sheikh Selim leads the group, and is portrayed with his beloved gun; he points at a direction with interrogative sight while looking at Vernet. The artist depicted him with characteristic sandals that seem to have been adjusted from a previous work rather than from observation. They feature in a painting made from 
nature in the surroundings of Annaba in Algeria, Rebecca à la fontaine (1833). Vernet's visual memory was legendary, ${ }^{93}$ but he could still make use of props, and art commanded distortions from the real scene to maximise effect.

When contrasted with his other works in the religious or genre manner, most partaking in the usual Orientalist kitsch, Voyage dans le désert has a convincing semblance of truthfulness that calls for attention. Was its naturalism topical or technological? As a matter of fact, photography, which meant daguerreotyping in this instance, had been a major part of Goupil-Fesquet and Vernet's activity during their tour. Looking into their images and related texts, art historian Michèle Hannoosh has suggested that the technology helped bring to the fore "elements of the haphazard, the momentary, the everyday or the historical that persist in even the most calculated photographic image" and, in doing so, conveyed a more nuanced and complex view of people and places encountered, than the usual lot of Orientalist formulas. ${ }^{94}$ The strong eye-to-eye connection between Vernet and Sheikh Selim that structures the composition of Voyage dans le désert, to the point of imposing itself as the central message of the canvas, is a brilliant rendering of a moment of interpersonal engagement, away from the common prejudices of the imaginary Orient, despite the asymmetry of their respective positions in the scene, Vernet up a camel, and Sheikh Selim standing below. Selim seems to be showing the way in response to a question by Vernet, who in turn assents to the direction pointed at. It does not come as a surprise that the artist would have chosen to disguise himself as an "Arab sheikh," with camel reins, at the costumed ball of Duke of Orléans in Paris, just a few months

93 “Tout s'y grave pour l'éternité, avec la fidélité du miroir," according to Goupil-Fesquet, Voyage, 22.

94 Michele Hanoosch, "Horace Vernet's Orient: Photography and the Eastern Mediterranean in 1839," The Burlington Magazine CLVIII (April 2016): 264-71 (Part I: a daguerrean excursion), CLX (June 2016): 43039 (Part II: the daguerreotypes and their texts), (439 for the quote). before finishing the oil painting. Did he purchase the guise during this travel?

\subsection{Engagements with Local Culture}

Representations of Europeans in popular apparel, i.e. à la longue, rather than in nizami garb, involved, more often than not, people, and in particular artists, that had developed a long and sustained acquaintance with the country. An example in photography represents Frank Dillon, bearded and turbaned, reclining, a chibouk by his side, on the sofa of the tiled and raised alcove emulating the recess of an Egyptian $q \bar{a}^{c} a$ at his London studio. ${ }^{95}$ A frequent traveller to Egypt, the British artist had already posed in similar attire for one of the most famous images of the Orientalist suite created by fellow photographer Roger Fenton in 1858, Pasha and Bayadère, in which he had impersonated an Arab musician with clothes brought from a recent trip to Cairo, while a dancing woman entertained a seated figure (Fenton himself), in a setting hastily arranged à l'orientale. ${ }^{96}$ Cultural cross-dressing was here associated with a highlyartificially staged tableau. The anonymous solo picture of Dillon at his place is of a distinct nature. It captures the British artist in deep rêverie. To be sure, the dozy smoker is known as a stereotypical image of a Near Eastern man at leisure. ${ }^{97}$ But what Dillon's posture embodies is rather the idea of "keif" (from the Arabic kaîf, literally mood, translated by Lane as "placid enjoyment"). ${ }^{98}$ Kaîf was among Egypt's best kept secrets, and one many (male) Europeans discovered with the utmost

95 Ken Jacobson, Odalisques \& Arabesques, fig. 7-2, 62; Dillon's studio is known from an illustration in Georg Ebers, Egypt, Descriptive, Historical and Picturesque (London: Cassel, Petter Galpin and Co, 1885), II: 85-6.

96 Gordon Baldwin, Roger Fenton, Pasha and Bayadère (Los Angeles: Getty Museum Studies on art, 1996); Gordon Baldwin et al., All the Mighty World: The Photographs of Roger Fenton, 1852-186o (London: Yale University Press, 2004), 84. For "à l'orientale" settings across Europe, Giese et al., eds., À l'orientale, Collecting, Displaying, passim.

97 Baldwin, Roger Fenton, Pasha and Bayadère, 65.

98 Lane, Manners, 338. 
delight. As Prisse d'Avennes detailed in his unpublished "Manners and customs of Egyptians in the nineteenth century:"

Le Keif indique cette heureuse disposition à jouir de ce qu'il y a de bon sous toutes les situations, où l'on se trouve sans trop s'inquiéter de ce qu'elles ont de mauvais. Le Keif sait jouir du confort lorsqu'il en a et s'en passer lorsqu'il ne l'a pas. Keif s'approche beaucoup du mot contentement - contentement pas richesse - mot bon à introduire dans notre langue. ${ }^{99}$

Attire, posture, and setting perfectly coincide in Dillon's reclining portrait. It can be contrasted with a carte-de-visite portrait featuring the architect Ambroise Baudry. ${ }^{100}$ (Fig. 160) The portrait is signed on the reverse by Facchinelli, which implies it was taken in Cairo in 1875 or 1876 at the earliest, four or five years after Baudry had settled in the city. At the time, the architect was working for the Khedive and wore a fez in everyday life. Yet, he chose to be photographed in a more vernacular outfit: the striped kaftan, the jubba, and the turban of the peasants or inhabitants of Cairo's popular neighbourhoods. He had grown a beard and is seated cross-legged on a sofa covered with kilims and saddle bags; he actually possessed his own saddle for camel riding. ${ }^{101}$ On the floor rests a smoking device differing from the usual types

Paris, Bibliothèque nationale de France, Manuscrits occidentaux, Nouvelles acquisitions françaises 20423, Émile Prisse d'Avennes, "Mœurs et coutumes des Égyptiens au XIX ${ }^{\mathrm{e}}$ siècle," f. 358. "Keif represents this happy predisposition leaning to enjoy the good in every situation, wherever one is and without worrying too much of their negative side. The Keif knows how to enjoy comfort when there is and do without when there isn't. Keif approaches greatly the word satisfaction - not wealth, it is a word worth introducing in our language." [My translation]

Marie-Élisabeth Loiseau, Jean-Pierre Remaud and Christophe Vital, Les Vendéens, grands voyageurs (Paris: Somogy Editions d'art, 1998), 84-5.

Loiseau et al., Les Vendéens, 85.

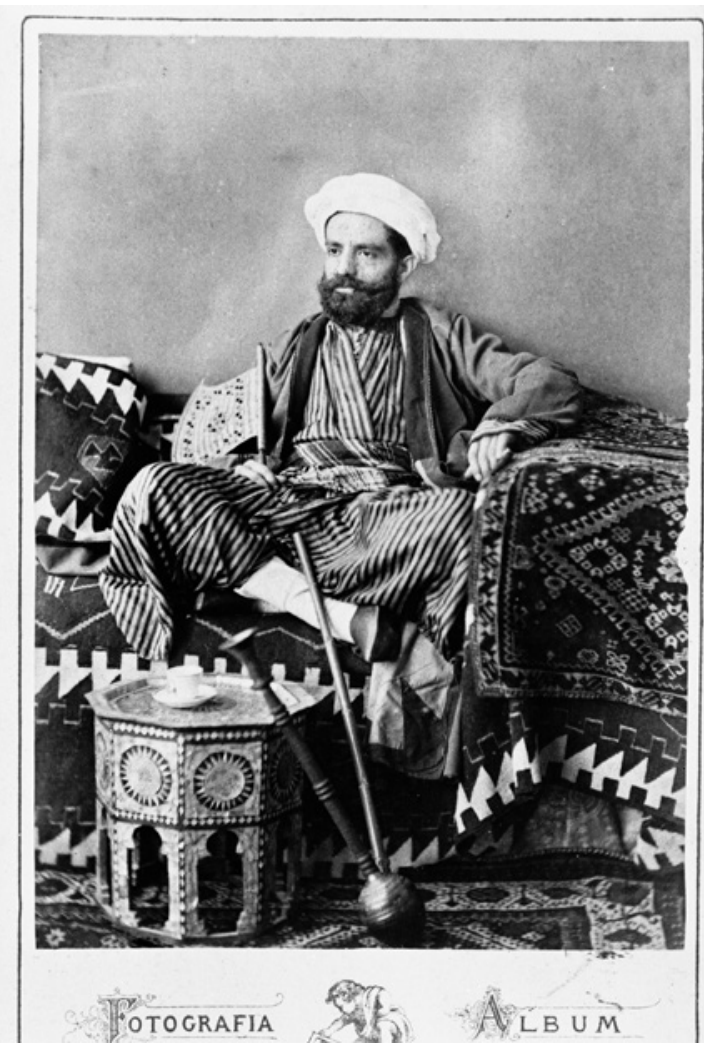

FIgURE 160 Beniamino Facchinelli, Ambroise Baudry en tenue arabe, c. 1876. [Ambroise Baudry in Arab garb]. Albumen print on board. Carte-de-visite format CONSERVATION DES MUSÉES DE VENDÉE

found in Orientalist painting; it is neither a shisha with glass reservoir, nor a chibouk, but the traditional güza used to smoke hashish. According to Lane, this kind of pipe, with short cane tube, was "used by men of the lowest classes, for smoking both the tumbāk and the intoxicating 'hasheesh,' or hemp." 102 There is no evidence that Baudry indulged in cannabis; every indication suggests rather the contrary. What is certain is that disguise, pose and props are meant here to stage a representation of Egyptian popular culture. The visual statement is congruent with the style of the house Baudry was building in Cairo at the time. As a journalist wrote:

102 Lane, Manners, 140. 
Un architecte érudit et inventeur, dont j'ai déjà parlé, M. Ambroise Baudry, a bâti au Caire une maison plus originale encore que toutes les maisons arabes. Les indigènes l'appellent une maison de fellah; il serait plus juste de dire que c'est une maison réellement égyptienne. Les murs en sont absolument droits et nus, sans encorbellement, sans moulures, sans corniche; seulement, pour éviter une monotonie désagréable, des briques rouges fixées dans la maçonnerie y dessinent les plus gracieuses broderies, tandis qu'un certain nombre de faïences plaquées dans la muraille contribuent encore à la gaieté de l'ensemble. C'est absolument le procédé que suivent les fellahs dans la construction de leurs cabanes, espèces de cubes de limon qu'ils décorent de quelques ornements en briques, et sur la porte ou les ouvertures desquelles ils placent un fond d'assiette ou quelque vieux plat qui simule la faïence. ${ }^{103}$

Baudry's "Fellah house" differed in effect from the over-worked Islamic style residences that were being erected by European expatriates and Egyptian high officials alike in Cairo. At least the facades of his house did. They were plainer than those of surrounding Islamic Revival buildings. The main decorative detail was a geometric strip in red bricks at the top of walls and fenestration,

103 Gabriel Charmes, "L'art arabe au Caire, III," Journal des Débats politiques et littéraires, 4 August 1881, 1. "A learned and creative architect, Mr. Ambroise Baudry, built in Cairo a house more original than all other Arab ones. The natives called it a fellah house; it will be more adequate to say that it is a truly Egyptian house. Walls are straight and bare, without protrusion, molding, or cornice; only, to avoid distasteful monotony, red bricks are fixed in the masonry and make gracious embroideries, while a few plates immured In the walls further contribute to the freshness of the whole. This is absolutely the device that peasants follow when building their dwellings, sorts of cubes in silt that they decorate with a few brick ornaments, and on the door and openings of which they place a dish's base or some old plate that simulated tiles." [My translation] inspired by the simple ornamentation of rural dwellings, when the other houses displayed rich arrangements of sculpted ornament, turned wood balconies, and bicoloured plastering, as shown in Chapter 4. Charmes was right in highlighting the originality of the design. Citations of vernacular architecture were unprecedented in Islamic Revival houses. In deep contrast with the facades, however, Baudry's interiors were as profuse as in those very houses. In other words, his architectural transgression of mainstream Orientalist aesthetics was relative. His portrait in popular apparel can be read similarly. It staged a specific impersonation, up to a certain point, and not to that of doziness in any case. Set in the context of Baudry's lifestyle in Cairo, the portrait confirms that clothing participated with dwelling in the projection of selves, although in a more restrained way than in Dillon's reclining likeness. Both photographs bring to the fore nuances in the range of local codes incorporated by Europeans in Egypt (from high to popular culture), and the extent to which they were (or not) embodied - as far as we can tell from the available iconography.

\subsection{Corporal Experiences}

It is safe to assume that the incorporation of local habits was highly selective. Some pastimes encountered stunning success. Tumba $\bar{k}$ is a good example of an Eastern product that went global at fast pace. Chibouk-smoking had practitioners in Europe from quite early on. A self-portrait of German architect Friedrich Maximilian Hessemer (180o-6o) stages him smoking the long pipe in his room in Rome in 1828 , before having set foot in the Eastern Mediterranean, or having even decided to visit. ${ }^{104}$ (Fig. 161) A later portrait while in Egypt represents him chibouk in hand, together this

104 Zwischen Aufklärung und Romantik: Zeichnungen, Aquarelle und Ölstudien aus der Gründungszeit des Hessischen Landesmuseums Darmstadt (Heidelberg Berlin: Kehrer, 2015), 288-89; Maryse Bideault, "Mein Fritz geht nach Aegypten!" Friedrich Maximilian Hessemer sur les traces de l'arc brisé au Caire, in Le Caire dessiné et photographié au XIX $X^{e}$ siècle, 17-40. 


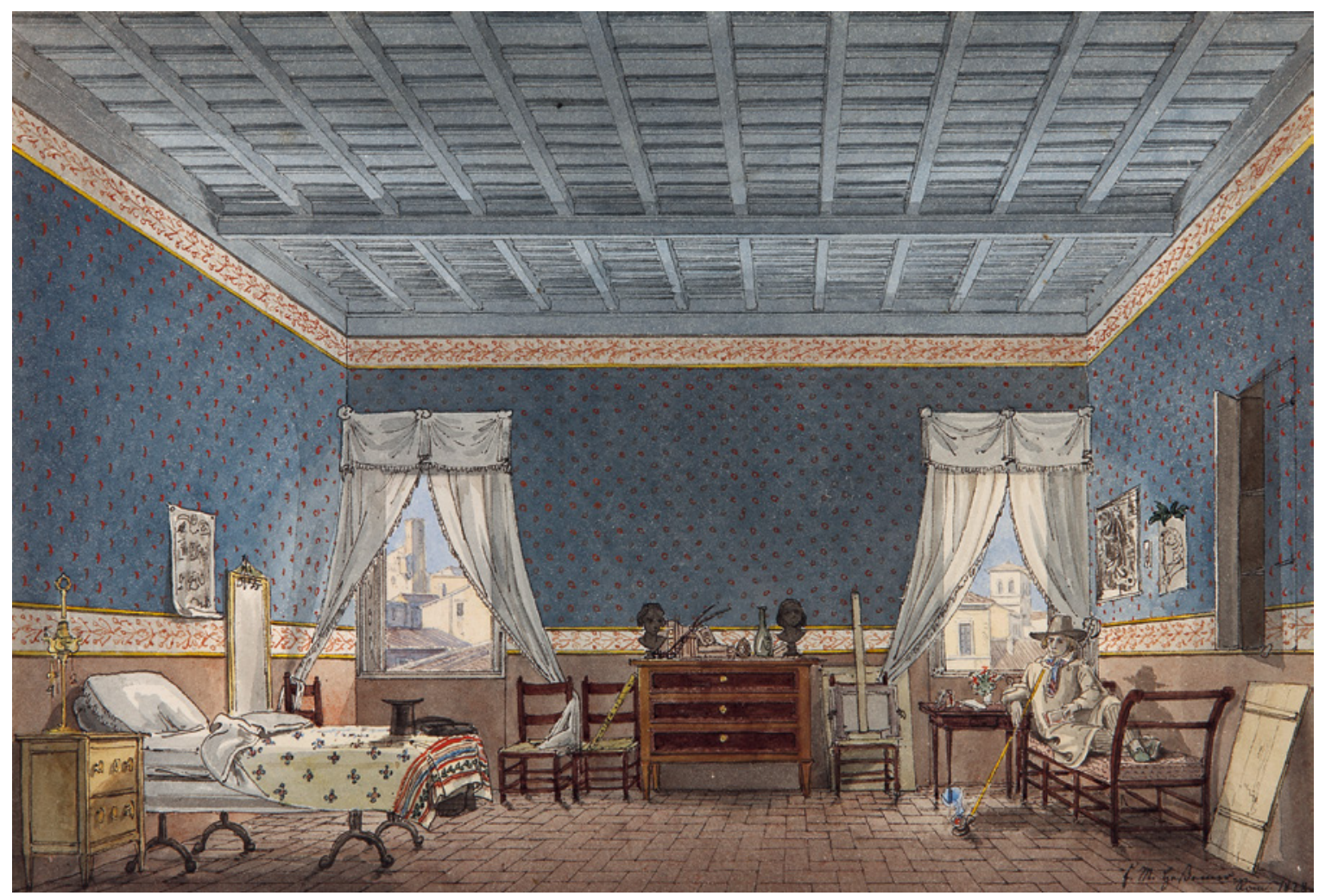

FIGURE 161 Friedrich Maximilian Hessemer, Self-portrait in Rome, 1828. Watercolour. $19.7 \times 29.2 \mathrm{~cm}$ DARMSTADT, HESSISCHEN LANDESMUSEUMS, HZ 2665

time with full local attire. ${ }^{105}$ (Fig. 162) The device figures in many travellers' portraits. The Turkish pipe holds centre stage in Horace Vernet's famous self-portrait painted in Rome in 1835. The artist had just built his Turkish Chamber in Rome, but had not yet set foot on Ottoman land. Paintings are certainly fictions, but they inform that the Turkish pipe, whether in reality or imagination, had fully entered the realm of European culture. Ten years later, "Parisian Turks," i.e. Frenchmen with some interest in, or acculturation to, the Ottoman Empire, could access a Cercle oriental [Oriental Club] where, crouching on Turkish rugs, they

105 Bideault, "Mein Fritz geht nach Aegypten!", fig. 2 from Friedrich Maximilian Hessemer (1800-1860) Ein Frankfurter Baumeister in Ägypten, eds. Jürgen Eichenauer and Clemens Greve (Frankfurt am Main: Waldemar Kramer, 2001), 244. could read the Ottoman official gazette [Moniteur ottoman] while smoking the exotic pipe. ${ }^{106}$

Direct experience of the East brought more than chibouk addiction: it introduced to new corporal attitudes. A suggestive example is given by a social gathering held in Paris in August 1843. The host was the visionary architect Hector Horeau (1801-1872), who was serving as first treasurer of the newlyformed Société orientale de France. The cenacle had been created in 1841 by concerned observers of the current state of affairs in the region who committed to leverage its potential for the "general progress of civilisation" and, to be sure, the "specific interests of France." ${ }^{107}$ Conditions of join-

\footnotetext{
106 "Le Cercle oriental," Le Charivari, 17 March 1846, 1.

107 Société orientale fondée à Paris en 1841, constituée et autorisée en 1842 conformément à la loi, 1843; Société orientale de France fondée à Paris en 1841 reconnue et
} 


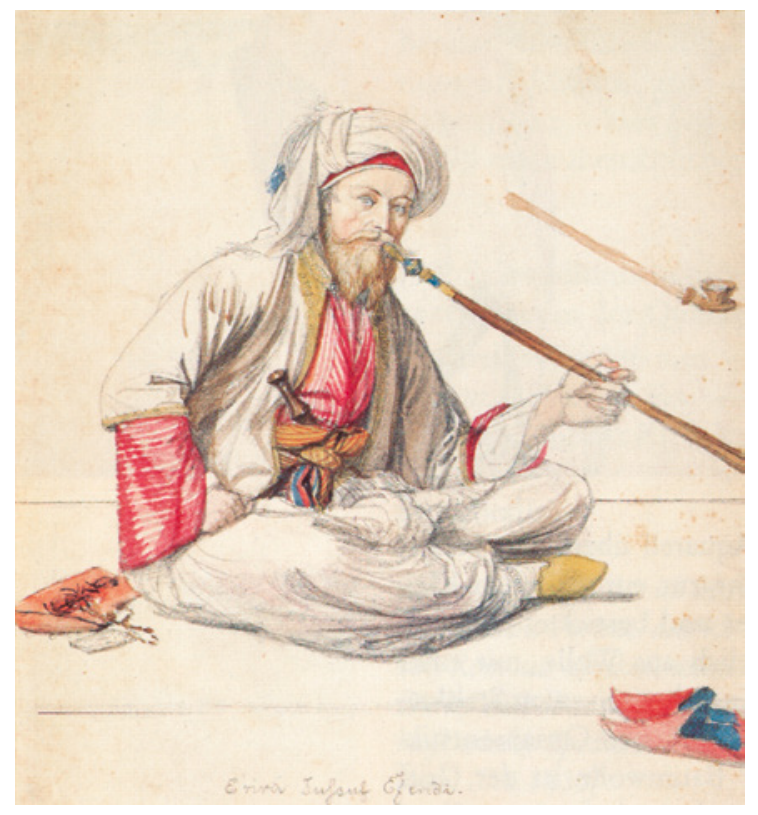

FIGURE 162 Wilhelm Ahlborn, Friedrich Maximilian Hessemer, aka Yussuf effendi, 183 o. Watercolour and graphite pencil. $21.8 \times 20.2 \mathrm{~cm}$ EIN FRANKFURTER BAUMEISTER IN ÄGYPTEN, FRANKFURT AM MAIN 2001: 244

ing the society were either to have been travelling in the East, have been studying it thoroughly, or have been producing artistic, scientific, literary, or economic works on Eastern issues. Many reputed scholars, artists, writers, diplomats and journalists were affiliated. The society acted as a lobby. At the initiative of Horeau, in 1846 it embarked on a public campaign for the establishment of a mosque, school and burial grounds for Muslims in Paris. ${ }^{108}$ Architectural drawings were prepared, but the projected buildings, the earliest of their kind, were never implemented. The initiative contributed, however, to public exposure to the issue of Islamic worship in France. A later attempt by Baudry and fellow architect Henri Saladin in 1895

autorisée par décision des ministres de l'intérieur et de l'instruction publique (Paris: Rouvier, 1853).

Pierrefite-sur-Seine, Archives nationales, F ${ }^{19} 10934$ folder 1, Projet d'établissement d'un collège, d'une mosquée et d'un cimetière musulman à Paris, 22 May 1846. also failed. ${ }^{109}$ It was only after World War I, once so many Muslims had died while fighting for France, that was a mosque erected in Paris. ${ }^{110}$

In attendance that evening in Summer 1843 at Horeau's place was another member of the Société orientale, the artist Charles Cournault (1815-1904), who kept a detailed note of the event, ${ }^{111}$ alongside an annotated print of the engraving that the illustrated press issued, after a sketch by Karl Girardet. ${ }^{112}$ (Fig. 163) Guests were artists and travellers who had sojourned in the East, in its broadest terms. Horeau himself had spent two years in the Eastern Mediterranean in 1837-39, and had just published a large portfolio from his excursion. He welcomed his guests under an elegant tent, only furnished with sofas. The dress code of the evening was Eastern clothing. Identified by Cournault at the far left of the print, was the scholar and collector Charles Schefer, in Nizami costume, chanting in "dolente voice an Arab song," to the sound of a small mandolin, one leg bent under the other. ${ }^{113}$ Smoking the narghile by his feet, and sitting crosslegged, was Girardet himself in Bedouin garb. At the other end of the image, Cournault donned the clothes of an Algerian Bedouin and also sat crosslegged, while the man serving drinks was Horeau dressed in Nizami garb. At the centre of the picture, a disciple of Ingres, Henri de Chacaton, wearing the Albanese fustanella, stood by a chibouk smoker dressed à la longue, possibly Horace Vernet himself, who was an honorary member of the Société orientale. The comment made in the press is no less captivating than the present sight of the disguised guests:

109 Pierrefite-sur-Seine, Archives nationales, F ${ }^{19}$ 10934, folder 2, Projet de construction d'une mosquée à Paris (1894-1905).

110 Pierre-Olivier Chaumet, "Aux origines de l'Islam en France. L'histoire controversée de la construction d'une mosquée parisienne au XIX ${ }^{\mathrm{e}}$ siècle (1846-1905)," Revue historique de droit français \& étranger 92, no. 3 (June-September 2014): 411-36.

111 Hecre, Les Orients de Charles Cournault, 92-5.

112 “Une soirée orientale à Paris," L'Illustration: journal universel II, no. 27, 2 September 1843, 4-5.

113 "Une soirée orientale," 5. 


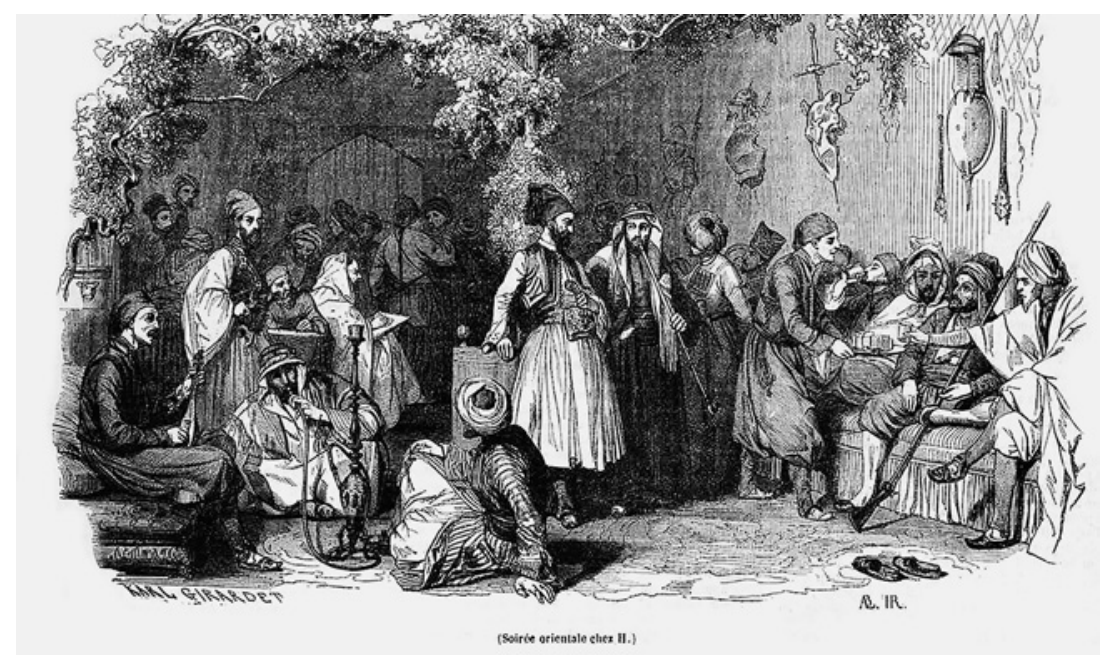

FIGURE 163 ALB HR, after a drawing by Karl Girardet. Soirée orientale chez H., [A party in Oriental attire at Hector Horeau's in Paris], 1843

L'ILLUSTRATION, JOURNAL UNIVERSEL II, NO. 27, 2 SEPTEMBER 1843: 5

Les artistes voyageurs et les voyageurs artistes gardent religieusement les costumes des pays qu'ils ont visités. Ce ne sont pas seulement pour eux de précieux souvenirs; ce sont aussi des preuves incontestables de leurs lointaines pérégrinations. [...] Les voyageurs aiment aussi à se parer des costumes qu'ils ont porté dans leurs courses aventureuses; ils y joignent s'ils le peuvent les gestes et le langage des pays lointains; alors la métamorphose est presque complète. [...] Tous les invités [de Horeau] portaient avec aisance des costumes orientaux d'une fidélité scrupuleuse. ${ }^{114}$

In other words, costumes played the role endorsed by photography, or rather digital images, today: a

114 "Une soirée orientale," 5. "Travelling artists and artist travellers religiously keep the costumes of the countries they visited. These are not only precious souvenirs; they are also uncontested proofs of their distant wanderings. [...] Travellers also enjoy donning the costumes they wore during the adventurous excursions; when possible, they add the gesture and language of the faraway countries; the metamorphosis is thus almost complete. [...] All attendees that night wore with ease costumes of a scrupulous accuracy." [My translation] proof of travel to be shown to others and a remembrance tool for one to enjoy. It explains why accuracy mattered so much: it authenticated the experience. Cross-cultural dressing was not only for travelling; it was prolonged when back home, and supplemented with related gestures, as well as language, when possible. The impersonation was meant to be absolute. Interestingly enough, all (male-only) guests of Horeau were said to be donning their Eastern garbs with ease. Not everyone knew how to.

From "placid contentment" [kaīf] to sitting postures, from chibouk smoking to camel riding, experiencing Egyptian culture engaged bodies well beyond dwelling and clothing. In time, it included enjoying the full hammam experience at home, as in Paris after $1875 .{ }^{115}$ More radical acculturations to Egyptian society had taken place in the early decades of the nineteenth century among Europeans settling in the country. "Renegades," i.e. converts, cut picturesque figures, appearing in several accounts. The Scottish-born

115 Avcioglu, Turquerie, Chapter 4 passim. An earlier, private, hammam is the one integrated in the Maison pompéienne built in 1868 by Prince Jérôme Napoléon in Paris. 
Osman effendi, mentioned above, was one of them. Captured by Mamluks in 1807 , freed nine years later, protected subsequently by Swiss Arabist Jean-Louis Burckhardt, Osman Effendi (originally William Taylor), became the main mediator between British travellers and Egyptian society until his death in $1835^{116}$ The same year saw the passing of one "Dr." Charles Dussap, a surviving nurse of the French expedition to Egypt, who had stayed behind and established himself as a physician. He had married an enslaved woman around 1818 and maintained others that he had freed in his household. ${ }^{117}$ Dressing à la longue, he was known by the nickname of Abū Daqn, for a legendary never-shaved beard, pictured by at least two artists. ${ }^{118}$ (Fig. 164) Dussap was tightly connected to the Saint-Simonians in Egypt (among whose were several converts). Saint-Simonians were followers of a French social and philosophical movement that preached peaceful exploitation of the globe, moral improvement of the most numerous classes, and new social roles for women; a group of them spent a few years in Egypt during the 1830 , and is credited with the idea of a

116 Thompson, "Osman Effendi."

117 Jacques Tagher, "Le Docteur Dussap, un français 'original' d'Égypte," Cahiers d'histoire égyptienne, Série III, no. 4 (May 1951):342-6; George Michael La Rue, "African slave women in Egypt, from ca. 1820 to the plague epidemic of 1834-35," in Women and Slavery: Volume One Africa and the Western Indian Ocean Islands, eds. Gwyn Campbell et al. (Athens: Ohio University Press, 2007), 168-89; Roger Botte, "Des Européens au marché aux esclaves: stade suprême de l'exotisme? Égypte, première moitié du XIX ${ }^{\mathrm{e}}$ siècle," Journal des africanistes 86, no. 2 (2016): 6-51.

One portrait is by Nestor L'Hôte, Portrait du Dr. Dussap, dessin à mine de plomb $(18,5 \times 14)$, album 1, no. 95 , Musée de Louvre, Département des antiquités égyptiennes; Joseph Bonomi left at least two portraits, one kept at the German Archaeological Institute in Cairo (Schmidt, Westcar on the Nile, 109: fig. 8o), and a different one published by J. Dickinson in London, a print of which, bearing date, signature and a long caption in Arabic, is in the Album of Drawings of Egyptian Subjects at the V\&A (SD.12O). The original drawing is at the Bibliothèque nationale de France (see caption of Fig. 164). canal joining the Red Sea to the Mediterranean. Dr. Dussap belonged also to a circle of British antiquarians who had endeavoured to live like "perfect Turks."119 One of them, James Burton, dressed in Eastern clothing, bore a beard of great length and walked with bare feet; the Egyptologist John Gardner Wilkinson reputedly ate with local table manners and equally dressed in Turkish attire. Both lived with enslaved women in houses located at the fringes of the city (Azbakiyya), where wealthy Turks resided. Wilkinson had undergone circumcision in order "to save his life if accused, by denying himself a Christian - he is in fact none buta confirmedDeist," reportedanacquaintance. ${ }^{120}$ Christians were forbidden to possess enslaved individuals; some long-time residents recurred to intermediaries, such as Osman Effendi, to acquire theirs. Playing that role for John Frederick Lewis in 1842, not without drama unfolding around the enslaved woman purchased, Émile Prisse d'Avennes prided himself on being able to pass as "a true believer" in any circumstance, thanks to his command of Arabic and intimate knowledge of local mores. ${ }^{121}$ In most, albeit not all, cases, this meant circumcision, a rather painful experience, graphically recorded by Saint-Simonian Ismayl Urbain after undergoing the surgery in $1835 .{ }^{122}$

Few enjoyed pushing the limits so far, and not everyone was able to easily bear, nor properly perform, the metamorphosis into (supposed) local selves. Head-shaving could already provoke

\footnotetext{
119 Rodenbeck, "Dressing native," 78.

120 Jason Thompson, Sir Gardner Wilkinson and His Circle (Austin: University of Texas Press, 1992), 53.

121 The tale of the episode figures in Prisse d'Avennes papers, Nouvelles acquisitions françaises 20420, f. 67-9 (Paris, Bibliothèque nationale de France, Département des manuscrits occidentaux); it is discussed in Briony Llewellyn, "Friend and foe: Émile Prisse d'Avennes, George Lloyd, John Frederick Lewis and the interconnecting circles of the British in Egypt," in Émile Prisse d'Avennes, 47-74.

122 Philippe Régnier, ed., Ismayl Urbain, Voyage d'Orient suivi de Poèmes d'Égypte et de Ménilmontant (Paris: L'Harmattan, 1993), 90-110.
} 


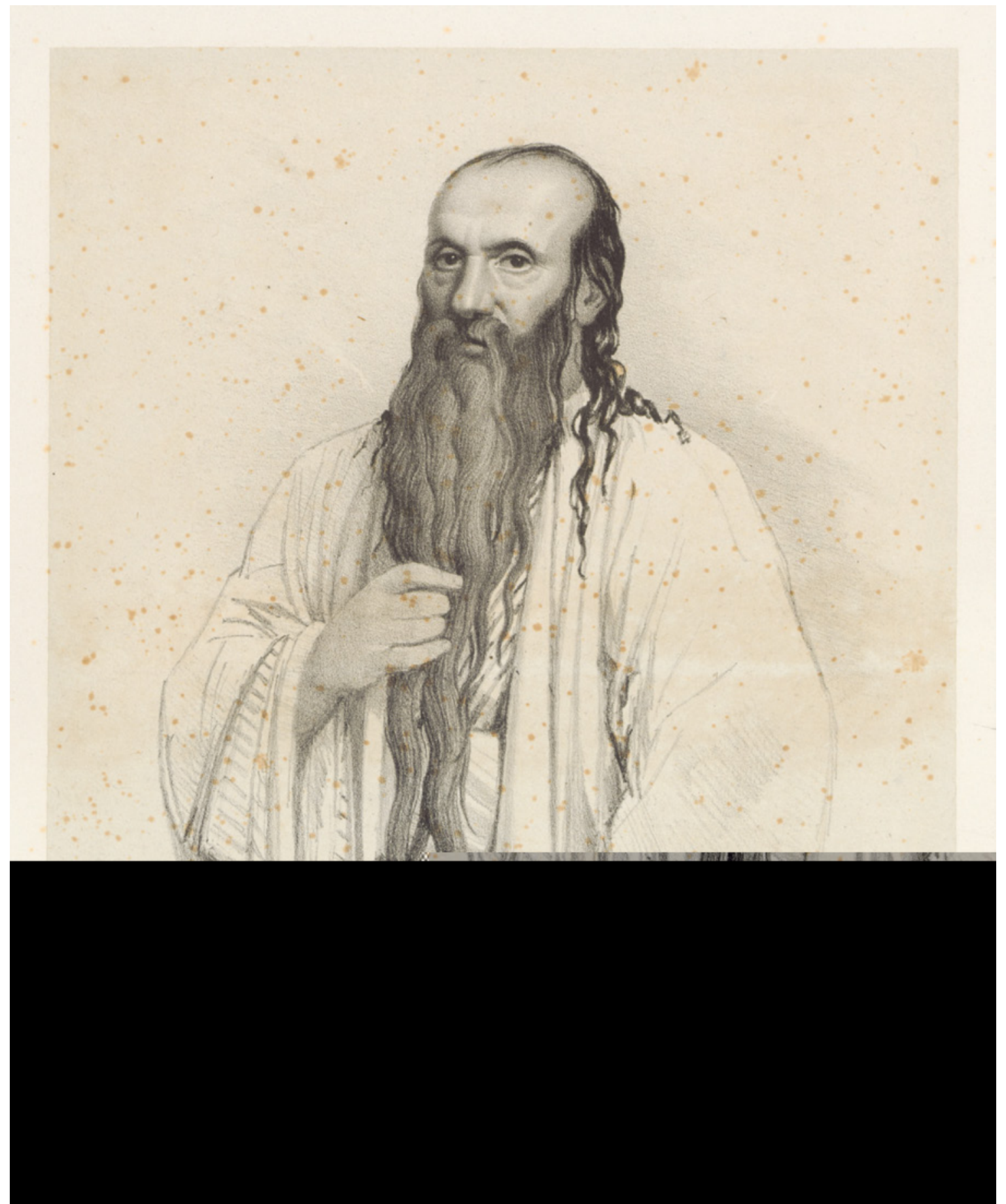

FIGURE 164

Al-Hajj B. [Joseph Bonomi], [Monsieur Dussap 1829]. This unsigned and undated drawing can be attributed with certainty to Bonomi on the basis of its dated, signed and Arabic-captioned engraved version kept at the V\&A, SD. 120. Charcoal on paper. $22.9 \mathrm{~cm} \times 18.5 \mathrm{~cm}$

PARIS, BIBLIOTHÈQUe NATIONALE DE FRANCE, MANUSCRITS OCCIDENTAUX, PRISSE D'AVENNES' PAPERS, NOUVELLES ACQUISITIONS FRANÇAISES 20441 (2), F. 4 
feelings of moral excruciation. ${ }^{123}$ Gérard de Nerval wrote in his travel account that he enjoyed the "transfiguration," but elsewhere spoke of the experience as a "crisis."124 Once cross-dressed, one needed to hold the right composure. The exercise was challenging. The Egyptologist Nestor L'Hôte (1804-1842) travelling with Jean-François Champollion along the Nile in $1828-30$, recalls an incident on this respect, with an unfortunate outcome. It involved British travellers who were wearing their Turkish costume with such awkwardness that they had to rush back to their place in order to avoid serious admonishment. Because they performed poorly in Turkish attire, passersby thought that their disguise was meant to be derisive. ${ }^{125}$ A similar story appears in the correspondence of the British Consul during the same years. It revolved around an "Ionian subject," i.e. under British protection, who had been sentenced to a beating when seen in oriental attire. As a result, a proclamation was issued "stating that the British Consulate could take no responsibility for or extend protection to British subjects who wore oriental dress." 26 The sentence was ultimately lifted, but it outlines the reality of the issue. Ten years later, Goupil-Fesquet was to offer a quite definitive statement on the matter of traveller's disguise:

Le touriste amateur, heureux dans ses babouches à pointes, possède toujours sous le caftan local la gaucherie de l'homme qui est dans l'habit d'un autre. ${ }^{127}$

123 Goupil-Fesquet, Voyage d'Horace Vernet, 8o.

124 Gérard de Nerval, Voyage en Orient, texte établi par Henri Lemaitre (Paris: Garnier frères, 1958), 182, 788; "Les barbiers turcs et leurs boutiques," Musée des familles VII (1850-51): 206-og.

125 Nestor L'Hôte, "Voyage archéographique et pittoresque dans la Vallée du Nil," Paris, Bibliothèque nationale de France, Département des manuscrits occidentaux, Papiers de J.-Fr. Champollion le jeune, Nouvelles acquisitions françaises 20377, Souvenirs de voyage, f. 124.

126 Thompson, Sir Gardner Wilkinson, 46.

127 Goupil-Fesquet, Voyage d'Horace Vernet, 120. "The amateur tourist, happy in his pointed slippers, always
This gaucherie is perceptible in many a likeness of Europeans in oriental attire, whether one considers the group portrait with Mark Twain (1867), or Baudry dressed à la longue (c. 1876). The selfportrait of photographer Francis Frith in Turkish Summer Costume (1857) is another telling example. (Fig. 165) There is something in the attitudes, whether a corporal rigidity, or an absent gaze, that feels not right - in other words, that denotes oddness. In contrast, some portraits project the nonchalance or panache with which their sitters wore the country's garb. The likenesses of Henry Abbott and Willem de Famars Testas come to mind, besides Horeau's guests at his Oriental evening. Whether the attitudes expressed in an artwork index the art of the painter or the ability of the portrayed is irrelevant here. What matters is the simultaneous existence of two main representations of Europeans wearing Middle Eastern attire, one exuding confidence and facility, and the other clumsiness. It can be assumed that the dual dynamics represent a fair assessment of the actual phenomenon.

\section{$3 \quad$ Costume for History and Leisure in Painting and Photography}

Frith's plate illustrating his travelling garb provided the opportunity of a broader commentary on the artistic eminence of Middle Eastern attire:

'Costume' is one of the most striking and interesting features of the East. [...] You will see at once that fashion has had little or no sway here. Every man robes himself according to his own free, gorgeous fancy. ${ }^{128}$

retains under the local caftan the gaucherie of a man wearing the garb of someone else." [My translation] Francis Frith, Egypt and Palestine Photographed and Described by Francis Frith (London: James S. Virtue, 1857), I: n.p. [9]. 


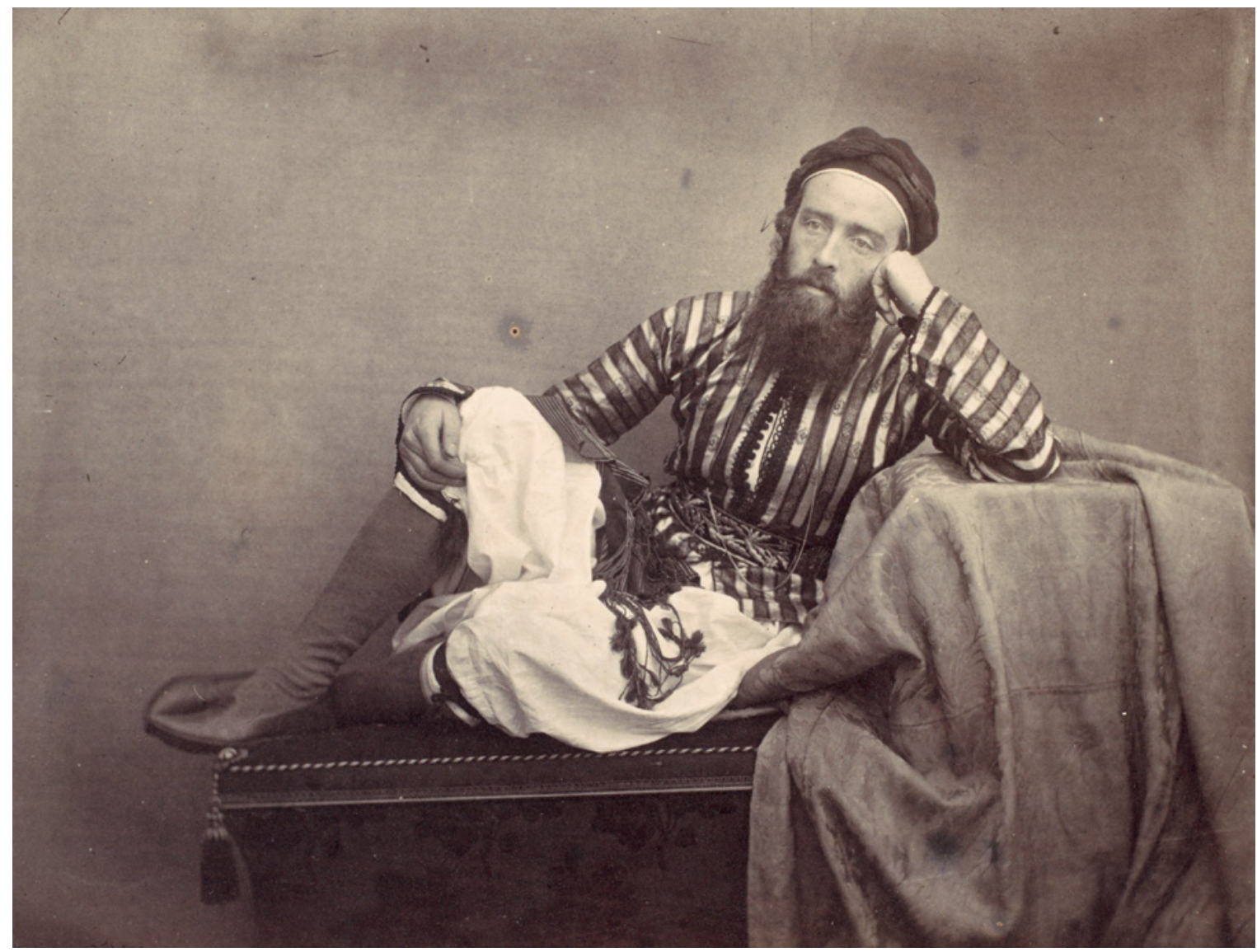

FIGURE 165 Francis Frith, Self Portrait in Turkish Summer Costume, 1857. Albumen silver print. 12.0 × 16.2 cm New York, Metropolitan Museum of Art, 66.640.2.4

As we have seen, that was not exactly the case. Ottoman dress codes were quite strict, and trends did determine length, colour, or arrangement. Within the standards set, fabrics certainly bore a range of impressive tints, at the discretion of the wearer, and to the point of approaching "Pre-Raphaelite brilliancy," in Frith's wording. Many would have subscribed to the statement. The British photographer was also enthralled by the extravagance of the suits, each worth thirty or forty pounds according to him, truly a substantial amount. ${ }^{129}$ Local garments possessed the extra appeal of being luxuries.

129 Frith, Egypt and Palestine, I: n.p. [9].
As comprehended so far, Middle Eastern apparel appeared in portraiture, whether the medium was oil painting or glass plate, within quite distinct perspectives since the eighteenth century. At stake were issues of travel and collecting, diplomacy and masquerade, remembrance and performance, norms and identities, besides the gusto for conspicuous consumption. Two further instances, in religious and genre scenes, are considered below.

\subsection{Picturing Biblical Scenes: The Holy Scripture "Arabised"?}

For Horace Vernet, wandering in the region two decades earlier, Middle Eastern attire had more to offer than brilliance and extravagance. It was a key to the past, to the Biblical past. Not that Francis 
Frith would have objected: among many others, he visited Egypt and the Holy Land in order to reclaim them for Christendom. ${ }^{130}$ Vernet's thoughts on the topic were expressed in a lecture given at the Académie des Beaux-arts in Paris in 1847. The talk was fully transcribed in the press under the title Des rapports qui existent entre le costume des anciens Hébreux et celui des Arabes modernes. ${ }^{131} \mathrm{It}$ was republished twelve years later as Opinion sur certains rapports qui existent entre le costume des anciens Hébreux et celui des Arabes modernes, ${ }^{132}$ and incited varied reactions. The argument and its critical reception deserve being followed in some length, as this does not seem to have been done so far. Indeed, Vernet's text is recurrently cited but it is commonly mentioned in passing, as if its title sufficed to form an idea about its content. ${ }^{133}$ I propose to consider it more seriously and have used for the purpose the version published in 1848 in L'Illustration, together with the sketches added by Vernet to illustrate his points.

Vernet started by recalling that he was in Algeria when he first came to realise that local scenes and gestures offered substance to passages in the Bible that otherwise made little sense to him, visually speaking that is. In essence, he was having trouble figuring out the exact movements involved in a scene of Genesis where Eliezer, Abraham's servant, first meets Rebecca at a well, and is being offered water from her jug. Vernet does not tell which edition of the Bible he was consulting, nor if it was an illustrated one. ${ }^{134}$ He just recalled always having

130 Douglas R. Nickel, Francis Frith in Egypt and Palestine: A Victorian Photographer Abroad (Princeton: Princeton University Press, 2003), Chapter 7 passim.

131 Horace Vernet, "Des rapports qui existent entre le costume des anciens Hébreux et celui des Arabes modernes," L'Illustration, 12 February 1848, 370-72.

132 Horace Vernet, Opinion sur certains rapports qui existent entre le costume des anciens Hébreux et celui des Arabes modernes (Paris: impr. de Bonaventure et Ducessois, 1856).

133 Annie Cartoux, "Horace Vernet, peintre de tableaux bibliques," Labyrinthe, no. 1 (1998): 45-62.

134 A plausible candidate would be La Sainte Bible: contenant l'Ancien et le Nouveau Testament / traduite en the Holy Book at hand when travelling, struck as he was by the actual resonance of the sacred text with what he saw.

The verse in Genesis (24:18) reads: "Drink, my lord': and she hasted, and let down her pitcher upon her hand, and gave him drink." ${ }^{35}$ The artist could not comprehend how Rebecca's jug could slide from her shoulder "over" her hand, until he saw in front of his eyes a young woman performing exactly the same gesture while satiating a soldier. The scene inspired his Rebecca à la fontaine, already mentioned. Made in the vicinity of Annaba in 1833 , the revelation convinced Vernet to dig further into the matter. After his epiphany, the artist embarked upon a restless quest to "push further the comparisons that could be drawn between the Scriptures and the surviving customs of the many people that had always lived under the influence of traditions, escaping that of innovations." ${ }^{136}$ Besides consulting the available literature, he sketched whatever relevant examples he could come across and acquired related artefacts.

Vernet delves further into his argument by taking the example of the canvas he was presenting at the Paris Salon that year, Le Bon Samaritain (1848). (Fig. 166) The scene is located on the very road leading to Jericho from Jerusalem where the parable of the Good Samaritan is set (Luke 10:25-37). A man on horseback discovers another, stripped of his clothes, lying in agony, and is about to rescue him. "Every detail is modern," Vernet notes, and "yet nothing is new, as every element concords with historic documents." The artist was not as interested in visually translating the moral message of the parable, as he admitted Poussin had magisterially done with his Eliézer et Rébecca

françois sur la Vulgate par M. Le Maistre de Saci (Paris: Defer de Maisonneuve, 1789-an XII [1804]), I:79, which reads: "Buvez, mon seigneur. Et ôtant aussitôt son vaisseau de dessus son épaule, et le penchant sur son bras, elle lui donna à boire." In a number of editions, for instance, in the King James Version.

${ }_{13} 6$ My translation from Vernet, "Des rapports qui existent entre le costume des anciens Hébreux," 370. 


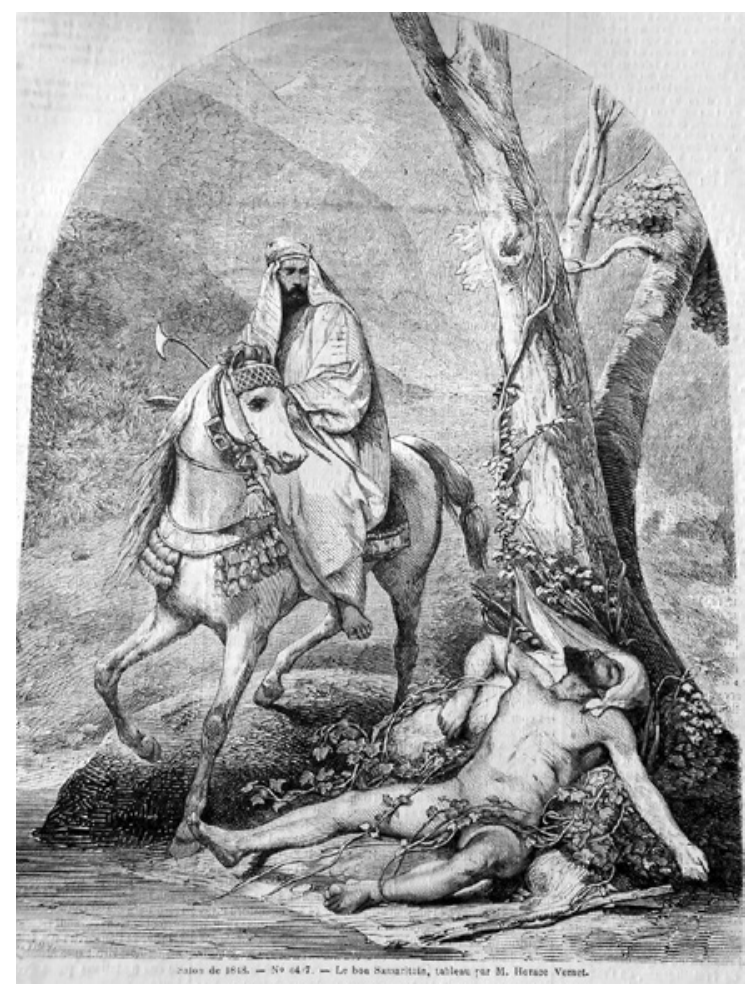

FIGURE 166 From Horace Vernet, Le Bon Samaritain, 1848. Engraving

L'ILLUSTRATION, JOURNAL UNIVERSEL, 25 MARCH 1848: 55

(1648). ${ }^{137}$ His concern was to get the man and his horse right; the intention was "to speak to the eyes, rather than to the soul."138 The material information Vernet needed for the purpose was provided from three distinct sources. One was attire purchased during his trip to Egypt and Syria in 1839 . Another was close observation of the tools used by the Arab people encountered during his journeys in North Africa and the Near East. The third was looking at the corresponding material culture in ancient remains, in order to guarantee its endurance over the ages. The stick that Vernet placed in the hands of the rider was one he said to have seen

137 Paris, Musée du Louvre, 7270.

138 My translation from Vernet, "Des rapports qui existent entre le costume des anciens Hébreux," 371. being used by contemporary Arabs; ${ }^{139}$ moreover it appeared in Pharaonic iconography which proved its antiquity. To ascertain the matter, Vernet presented a drawing at the end of his text, although without specific identification. The tack of the horse was copied on an existing one observed during Vernet's brief journey to Isly (then Morocco, at the frontier with Algeria) in March 1845; its presence in Antiquity was again testified by archaeological remains. The evidence this time came from a bas-relief from Khorsabad (Nineveh) representing a horse parade that had just been exhibited at the Louvre; on one of the horses, Vernet had spotted pieces very close to the ones observed at Isly. Both drawings, the horse trappings sketched in Morocco in 1845 and the one copying an Assyrian low-relief dated eighth century BC seen at the Louvre, ${ }^{140}$ were also appended to his publication.

In short, Vernet, in order to represent a Biblical scene, used sketches from his journey to the Holy Land; garments purchased there; a cane seen in Algeria that featured in Ancient Egyptian murals and horse tack observed from life in Morocco and on ancient Iraqi stonework. Alternatively put, he combined material from faraway times and places, as if history and geography did not matter. The result was not religious or historical painting, but almost genre pieces out of time.

The critical responses to Vernet's "Arab-biblical obsession"141 were lukewarm to say the least. Some agreed that it was time to explore alternatives to the classical Greco-Roman imaging of the holy text, but were not convinced by the "Bedouin" formula proposed by Vernet, nor by the contemporary expressions of his characters. ${ }^{142}$ What was

139 Coincidentally (or not?), the item appears in one of the plates of Prisse d'Avennes' Oriental Album released that very year (pl. 20).

140 Paris, Musée du Louvre, Relief des tributaires mèdes, AO 19887 .

141 Léon Lagrange, "Horace Vernet II," Gazette des beauxarts XV (November 1863): 439-65.

142 Charles Lenormant, "Critique artistique du Salon de 1835," Revue des deux mondes, t. II (April-June 1835): 167-209 (208). 
meant by "Arabising the Bible,"143 was in fact setting it into nomadic culture. Others concurred that dressing ancient Hebrews like modern Arabs was a promising idea, even if running against the tradition of religious painting, but considered that Vernet's interpretation fared poorly artistically speaking and disrespected the "dignity of history."144 His biblical scenes were handled in an informal way, which was disturbing to the beholder; they were considered irreverent. More aptly to the contemporary historian, the art critic Léon Lagrange objected to the Arab immutability fictionalised by Vernet:

L'histoire est là qui nous dit combien de civilisations diverses ont balayé le sol de l'Orient, jetant chacune dans l'industrie et le commerce, c'est-à-dire jusqu'au fond des déserts, des modes, des étoffes, un mobilier nouveau. Le bon sens nous oblige à reconnaître entre les pays et les peuples qu'a ralliés l'unité mahométane des différences profondes. Quant à cette prétendue immobilité de l'Orient, l'expérience personnelle nous a montré, dans la Haute Nubie, la forme $\mathrm{du}$ bonnet rouge, $\mathrm{du}$ fez, variant suivant la dernière mode venue de Constantinople. [...] Ne tenir aucun compte de l'histoire, ne voir que le détail accidentel de la réalité, c'est ouvrir la porte à toutes les contradictions. ${ }^{145}$

143 Vernet had been accused of attempts to "arabise the Bible" by archaeologist Charles Lenormand; Vernet, "Des rapports qui existent entre le costume des anciens Hébreux," 370.

144 Amédée Durande, Joseph, Carle et Horace Vernet: correspondance et biographies (Paris: J. Hetzel, 1864), 331-33; Arsène Houssaye, "Le Salon de 1843 III," Revue de Paris 16 (1843): 107-27 (116-17).

145 Lagrange, "Horace Vernet II," 46o. "History tells us how many diverse civilisations took place in the East, each throwing into industry and trade, deep into the furthest desert, new fashions, fabrics and furnishings. Common sense obliges us to recognise sharp differences among countries and peoples assembled under the unity of Islam. As to the alleged immobility of the East, personal experience has showed us, in Upper Nubia, the form of the red cap, the fez, varying along
Vernet's imagined world was in fact a fast changing one, and the late Ottoman Empire was no exception: the shape of the fez in distant Upper Nubia was defined by the latest fashion in Istanbul. Negating history was an error.

Somehow, a definite assessment came from the famous writer and literary critic Sainte-Beuve (1804-69). Offering some posthumous support to Vernet's anecdotal and literal realism, he saw little chance yet for his theory to be accepted. Fighting a stereotype solidly installed over three centuries in religious painting required stronger impetus. A string of masterpieces would be needed to establish a new figurative standard in religious art and heviewed thelikelihood of thisalmostinexistent. ${ }^{146}$ As for Théophile Gautier, the most prominent critical voice of the time, pictorial traditions had to be pursued even if admittedly erroneous. ${ }^{147}$

Grasping these discussions today is demanding. Few people in Europe have the Scriptures as regular reading, let alone travel with the text in hand. The current material turn in art and cultural history invites empathy with Vernet's interest in ethnographical artefacts, but his ahistorical vision runs counter to the present awareness of historicity and temporal change, at least for the cultural historian. His obsession with ethnographic accuracy in guise and gesture in his biblical scenes, as opposed to engagement with topic and expression, appears to be deeply rooted in times and rationales that have become alien to us, while deeply informative about the place of costume in art and historical thinking then. This is why it is so crucial to take such imagery seriously and understand it from within, rather than from above.

the latest fashion from Constantinople. [...] Ignoring history, noticing only the anecdotal details of reality, equates opening the doors to all sorts of contradictions." [My translation]

146 Charles-Augustin Sainte-Beuve, Nouveaux Lundis (Paris: Michel Lévy frères, 1866), v: 104-05.

147 Théophile Gautier, Les Beaux-Arts en Europe - 1855, Seconde série (Paris: Michel Lévy frères, 1856), 10-21 (20). 


\subsection{Sartorial Animations}

The same applies to the sartorial performances associated with Islamic style rooms. We are far estranged from such scenes today as well, and yet they are an integral part of Islamic historicism in architecture. These events were seldom publicised, but a few were mediated through canvas or staged on glass plate. Insights can be gained from enactments that took place in three different settings: one was Villa Delort de Gléon in Cairo, and the two others were Goupil's Oriental and Renaissance galleries and Henry-René D'Allemagne's Islamic style rooms, both in Paris.

The earliest evidence is provided in a letter by Finnish painter Gunnar Berndtson (1854-95) dated 26 March $1883 .{ }^{148}$ The artist had been in Cairo since October 1882. He had proceeded there from Paris, after having been encouraged by French fellow painters to visit the Egyptian capital. In Paris, Berndtson was part of the artistic circle surrounding Jean-Léon Gérôme, a group well connected to Cairo, and in particular to art collector and patron Baron Delort de Gléon. Events unfolding in the Egyptian city made the journey timely. The country had just been occupied by the British, following rebellion within the ranks of the army. The trial of the main leader of the uprisings, Colonel Ahmad 'Urabi, was due to start in December. The event drew crowds of journalists and draughtsmen with commissions to report to the European press. Berndtson himself travelled under contract with Le Monde illustré. In Cairo, he soon became a regular guest at Delort de Gléon's dining table. The French entrepreneur had created his own informal version of the "Villa Medici," i.e. French Académie in Rome, in the grounds of his property where visiting artists could secure studio space and models. In residence at the time was the French Marius Michel, and the

148 The letter is reproduced, translated from Swedish and discussed in Elina Heikka, "Layers of fantasies: Gunnar Berndtson's Almée," Finnish National Gallery Research, no. 5 (2017): 1-28.
American Julius Leblanc Stewart had been visiting in $1881 .{ }^{149}$ Evenings were busy: time was spent playing music, reading, modelling wax figures, or gambling. ${ }^{150}$ The passing mention of ceroplastics as social entertainment sheds further light on the artistic life at Villa Delort de Gléon. The scope of engagement with art went beyond the activity of established artists, it involved amateurship as well. The Baron himself was an amateur photographer, who had studied painting with Gérôme and had his portrait painted by the master.

Berndtson's letter describes a grand party thrown by Delort in honour of an affluent young heir, Auguste Bamberger (1864-1915), the son of bank magnate Henri Bamberger, who had many business interests in the region. An intimate dinner preceded the reception. The attendees were, besides the guest of honour, Delort de Gléon himself, his neighbour Count Gaston de Saint-Maurice, and the Finnish artist. All three donned Arab attire and kept the guise during the rest of the evening. Other guests joined after dinner to attend the performance of six almées [dancers] with four accompanying "Arab musicians." Berndtson was fascinated by the attire of the dancers:

The costumes of the almées were extraordinary, a small vest that covered the shoulders and chest, a veil covering the waist and broad trousers made of silk with gold embroidering, held up by a gold brocade belt; silver and gold bangles on their wrists and ankles and thick gold chains around their neck, brilliant medallions and other jewellery, fingers full of rings. ${ }^{151}$

Contrary to automatic assumptions, based on Flaubert's carnal encounter with Kütchük Hanem [from Turkish, literally the Little Lady] in 1850,152

\footnotetext{
149 Volait, Fous du Caire, 99-104.

150 Heikka, "Layers of fantaisies," 13-4.

$15^{1}$ Heikka, "Layers of fantasies," 28.

152 Auriant, Koutchouk-Hanem, l'Almée de Flaubert (Paris: Mercure de France, 1943).
} 
iconic paintings (e.g. Gérôme's Almeh, 1863), ${ }^{153}$ or later postcolonial stereotypes, ${ }^{154}$ almehs usually performed in decent and substantial clothing. According to Lane:

The dress in which they generally exhibit in public is similar to what is worn by women of the middle classes in Egypt in private; that is, in the harem; consisting of a yelek [long vest], or an anteree [gown], and the shintiyan [trousers], etc., of handsome materials. ${ }^{155}$

The British scholar recalls that when dancing for a private party of men, some dancers may have only worn a tob [wide-sleeved shirt] of semitransparent coloured gauze, largely opened, over their trousers. ${ }^{156}$ It is unlikely that this would have happened at Delort's with a nineteen-year old guest of honour in attendance and less so, under the grip of rising British Victorianism in the country. ${ }^{157}$ There is no evidence either that the dancing costume observed by Lane in the 183 os survived unchanged into the 188 os. What the dancers wore that evening is probably close to the costumes of the three performers that Delort conveyed to Paris a few years later within the framework of the Rue du Caire, the recreation of a Cairo street that he sponsored at the 1889 Exposition Universelle. (Fig. 167) The spectacle in Paris involved four musicians, possibly the same ones playing at the March 1883 event. (Fig. 168)

Colour depictions, in watercolour or on glass plate, convey analogous modesty. In 1868, travelling in Egypt with Gérôme, Goupil, and their friends, Famars Testas recorded for his comrades

\footnotetext{
153 Laurence des Cars et al.,Jean-Léon Gérôme (Paris: ESFP, 2010), 258-59.

154 For the eroticization of belly dancers in Egyptian postcolonial fiction, Frédéric Lagrange, "L'adib et l'almée: Images de la musicienne professionnelle chez Nagib Mahfuz et Tawfiq al-Hakim," Annales islamologiques 43 (2009): 337-75.

155 Lane, Manners and Customs, $384-85$.

156 Ibidem, 386.

157 Karin van Nieuwkerk, “A Trade like Any Other:” Female Singers and Dancers in Egypt (Austin, TX: University of Texas Press, 1995), 34-7.
}

an impromptu dance that took place under their tent in the oasis of Fayyum (Fig. 169) The scene is described in some detail in the travel account of the journey. ${ }^{158}$ The watercolour is unusual for it brings together a local dancer and her band, Western artists, their Egyptian servants, and Fayyumi notables. It captures a lived moment rather than a constructed stereotype, in contrast to many an Orientalist canvas. ${ }^{159}$ A comparable sense of innocent trade is perceptible in the later photographic portrait of a young dancer made in Cairo by Jules Gervais-Courtellemont. ${ }^{160}$ (Fig. 170)

In his letter back home, Berndtson confessed having felt little interest in the dance, "monotonous and calm," and found the music "tiresome and noisy." What had enthralled him was the atmosphere produced by the whole scenery in the setting of Delort's parlour. A month earlier, the artist had started a "small interior piece" depicting the colourful Islamic Revival design of the room. Delort was pleased and willing to acquire the canvas; he expressed desire to feature in it in Arab attire. It is not indicated if Delort meant à la longue or Nizami garb. Berndtson's response was to "animate the painting" with the figure of a belly dancer. He chose to have her performing the legendary bee dance (a form of striptease), in front of Delort and his close friend Octave Borelli sitting in the background. ${ }^{161}$ Their gaze is caught by the bare breast of the dancer, which is lost, in contrast, to the beholder. The seen and concealed game is typical of Gérôme's art, as best exemplified by his Snake Charmer, ${ }^{162}$ a piece created a few

\footnotetext{
158 Paul Lenoir, Le Fayoum, Le Sinaï et Pétra: expédition dans la Moyenne Égypte et l'Arabie Pétrée, sous la direction de J.-L. Gérôme (Paris: Henri Plon, 1872), 103.

159

160 Nochlin, "The imaginary Orient," 33-59.

"Along the banks of the colorful Nile: 23 natural color photographs by Gervais Courtellemont," National Geographic Magazine 50, no. 3 (September 1926): 314-38.

161 Heikka, "Layers of fantasy."

162 Williamstown, MA, Sterling and Francine Clark Art Institute, 1955.51; Marc Gottlieb, "Gérôme's Cinematic Imagination," in Reconsidering Gérôme, eds. Scott Allan and Mary Morton (Los Angeles: J. Paul Getty Museum, 2010), 54-64.
} 


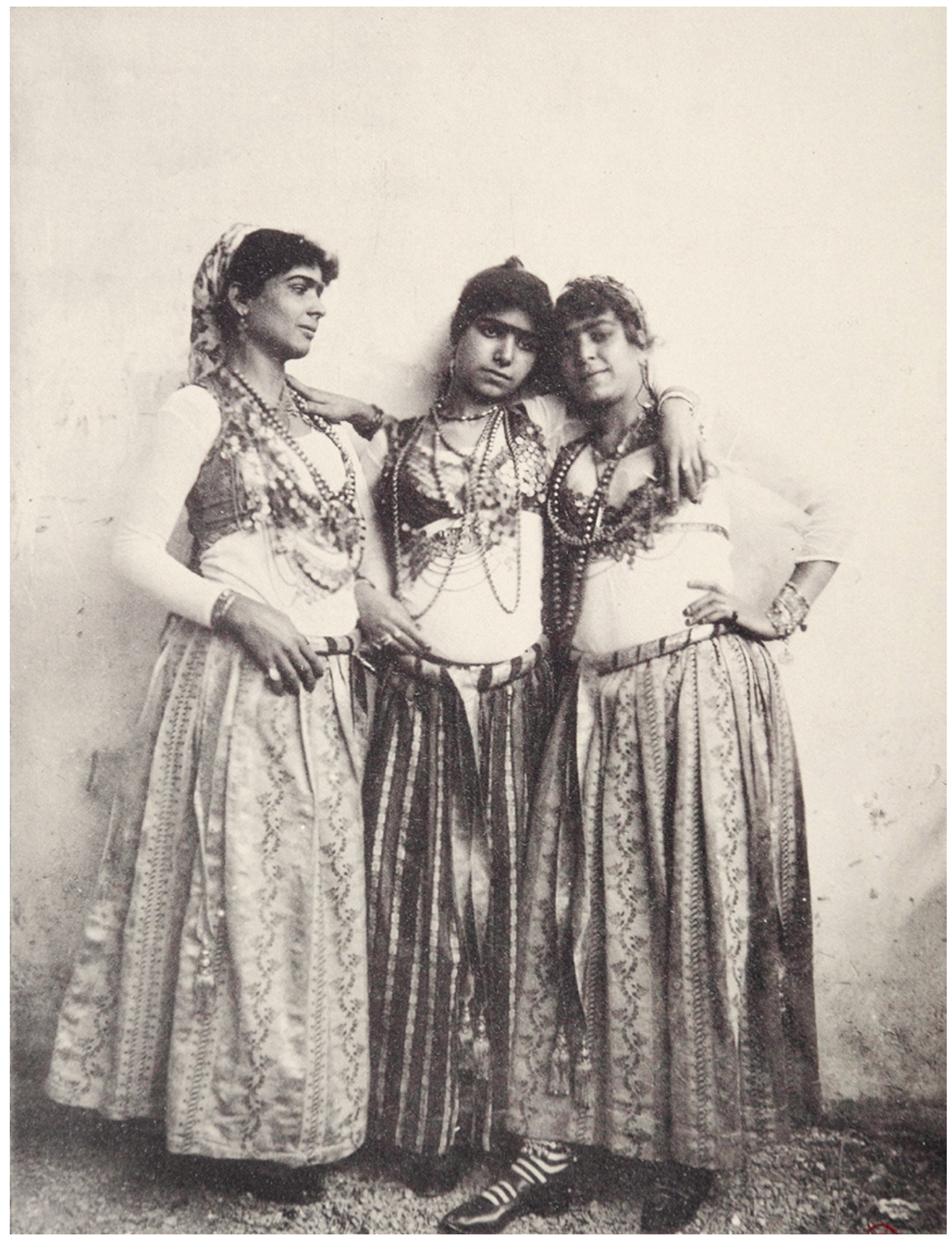

FIGURE 167 Alphonse Delort de Gléon, Types de danseuses indigènes, 1889. Three Egyptian performers photographed in Paris in 1889. Lithograph

L'ARCHITECTURE ARABE DES KHALIFES D'ÉGYPTE À L'EXPOSITION UNIVERSELLE DE PARIS EN 1889: LA RUE DU CAIRE 1889: PL. 26 


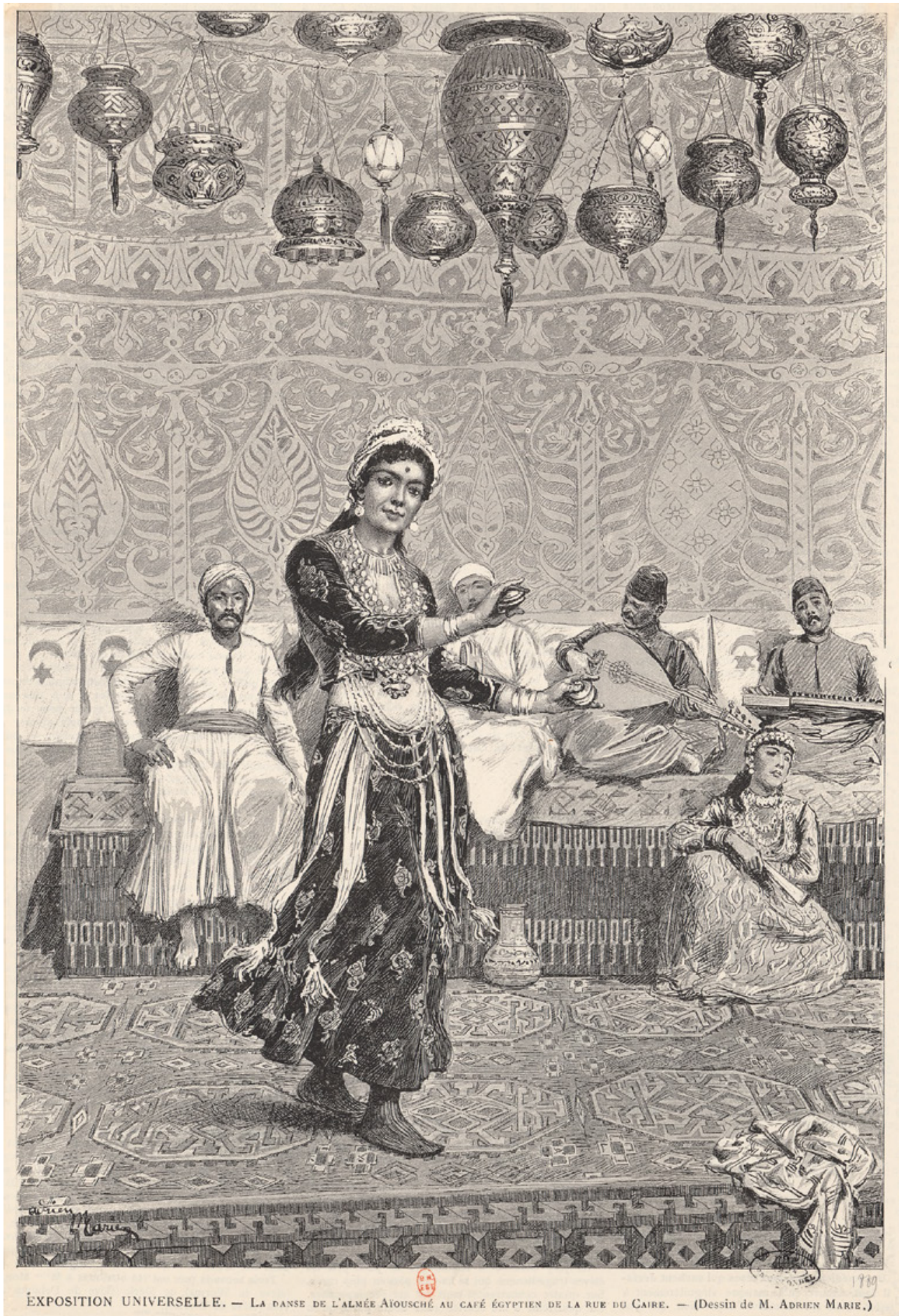

FIgURE 168 After Adrien Marie, La Danse de l'almée Aïouché au café égyptien de la rue du Caire, 1889 PARIS, BIBLIOTHÈQUE NATIONALE DE FRANCE, ESTAMPES ET PHOTOGRAPHIE, H56919 


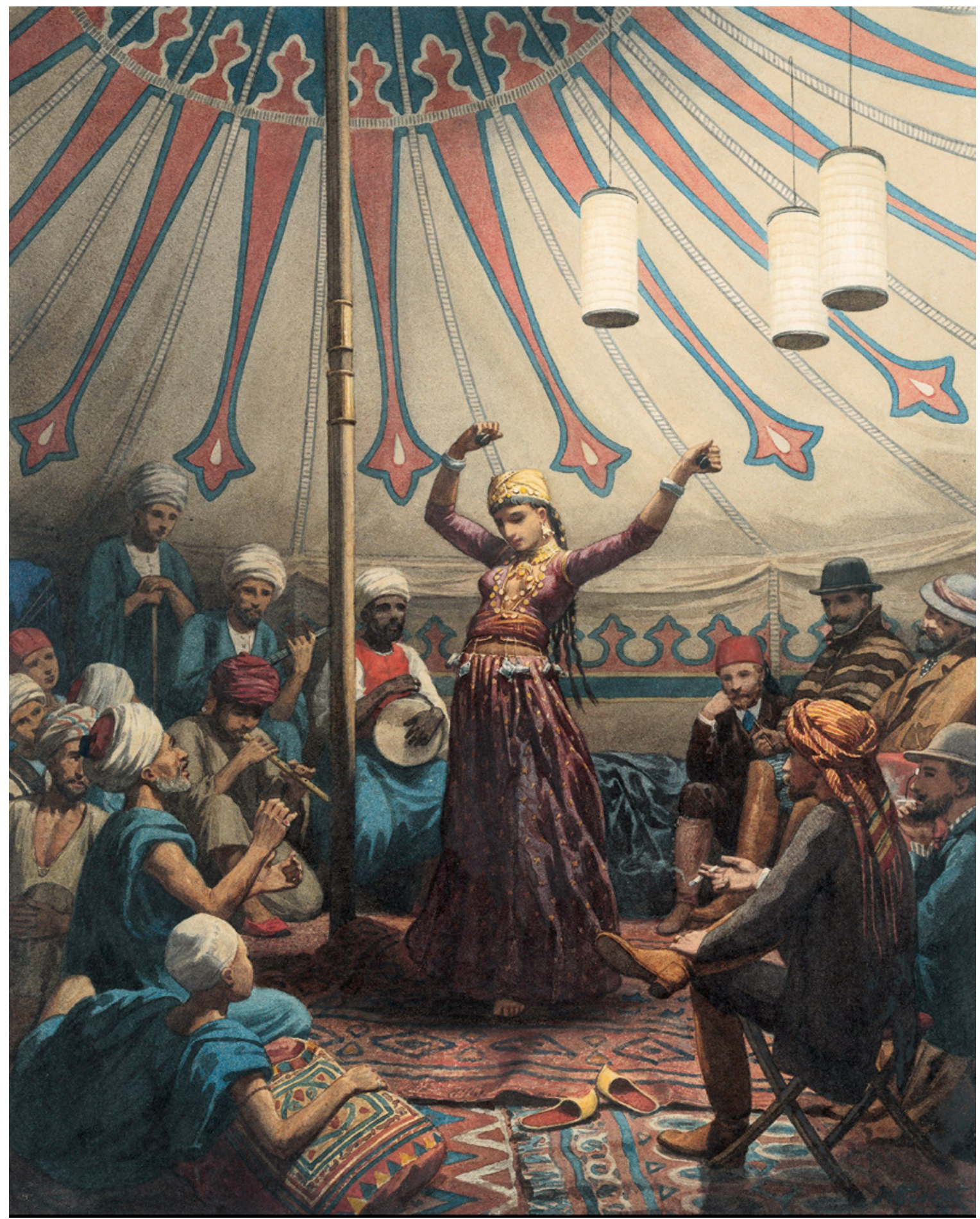

FIGURE 169 Willem de Famars Testas, Souvenir de Senouris dans le Fayyoum, 6 February 1868. Watercolour on paper. $32.3 \times 25.8 \mathrm{~cm}$

AMSTERDAM, RIJKSMUSEUM, RP-T-1892-A-2698 


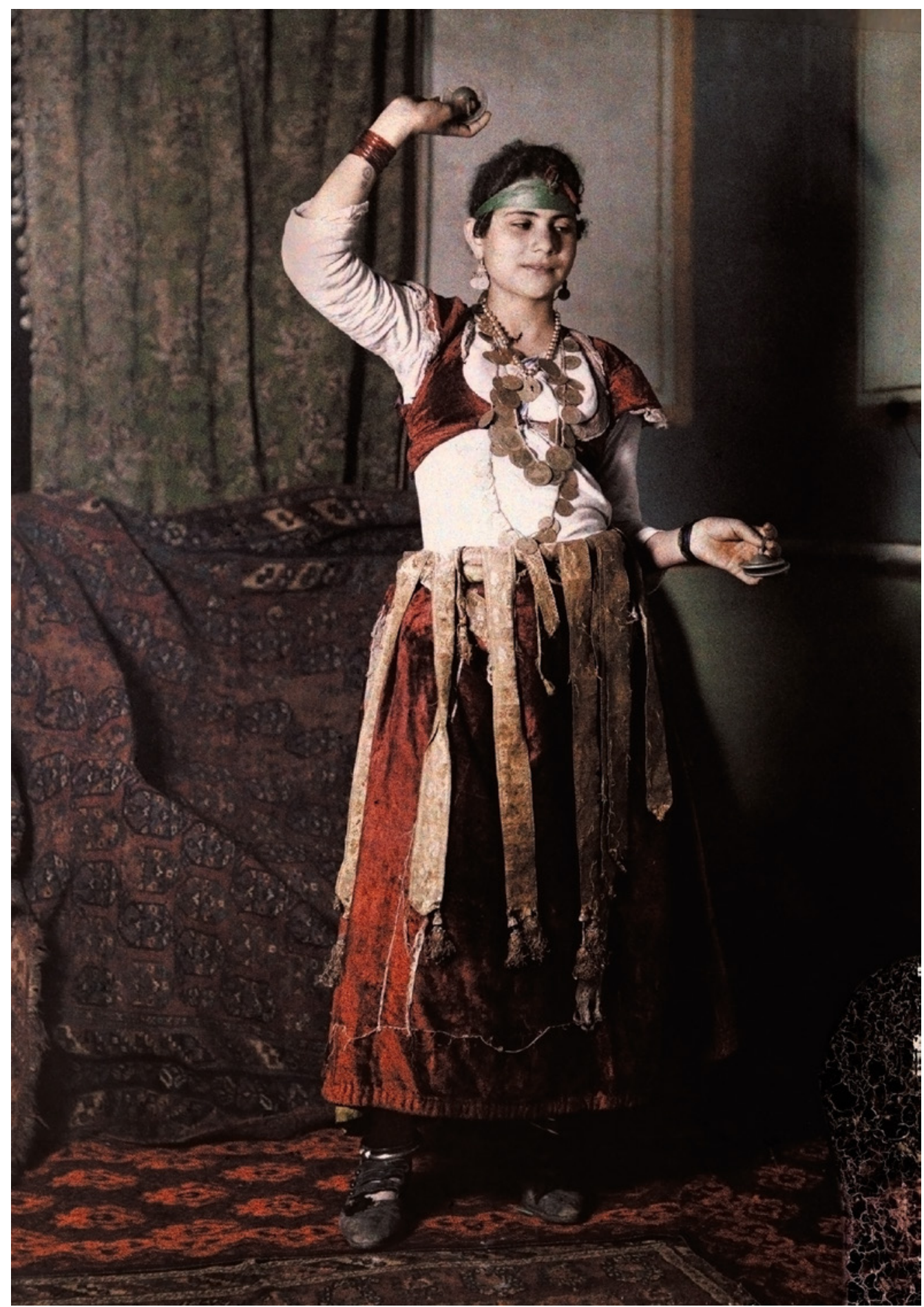

FIGURE 170 Jules Gervais-Courtellemont, Young Belly Dancer, 1926. Autochrome Lumière WASHINGTON, DC, NATIONAL GEOGRAPHIC SOCIETY, NO. 940009 
years earlier and certainly known to Berndtson. Paul Baudry's Salomé (1875) also comes to mind, because of its very close composition: a dancer seen from the back performs under transparent gauze before a reclining Herod. ${ }^{163}$ Because of his close connection to his brother Ambroise, Paul Baudry's art was not unknown in this Cairene circle. On the other hand, Salomania was on the rise; her dance and the idea of the femme fatale became a major literary and artistic trope in fin-de-siècle Europe. Salomé's nudity was Baudry's alteration of the Biblical episode (Matthew 14:1-10); the performance was to be baptised The Dance of the Seven Veils by Oscar Wilde in $1893{ }^{164}$

Contrary to Delort's wish, the two Frenchmen figure in European attire, while the dancer, as aptly noted by art historian Elina Heikka, holds a posture corresponding to classical ballet, in place of belly dancing. The model may not have been Egyptian either. A similar figure, posing nude by an early Mamluk ewer from Delort de Gléon's collection, was painted by Julius Leblanc Stewart during his time at Cairo's Villa Medici; her features do not look Egyptian, although she could have been a descendant of white enslaved women. ${ }^{165}$ Whatever the case, Berndtson has somehow "Europeanised" his rendering of private entertainment at Delort's, by not clothing the viewers in Arab guise, and choosing a ballet gesture over belly dancing movement. It is not evening either, but seemingly midday or early afternoon. The ballet touch might have been dictated by model availability, rather than intention, but the contemporary association

163 Christophe Vital, ed., Paul Baudry (1828-1886), Les portraits et les nus (Paris: Somogy, 2007), 190-91.

164 Johannes Hendrikus Burgers, "The spectral Salome: Salomania and Fin-de-Siècle sexology and racial theory," In Decadence, Degeneration, and the End, eds. Marja Härmänmaa and Christopher Nissen (New York: Palgrave Macmillan, 2014), 165-81.

165 L'Esclave, $1881,76 \times 48 \mathrm{~cm}$, lot 147 , auction sale by Conan, Hôtel d'Alnay, Lyons, 3 December 2017. The ewer is now at the Louvre (OA 7427). It is signed and dated (1309), and bears characteristic ducks and Zodiac signs. of belly dancing with vulgar sensuality might have mattered too. Gérôme's Almée (1864) had been harshly criticised on this ground after its Salon presentation, by Gustave Moreau in particular. ${ }^{166}$ An American student of Gérôme, Harry Humphrey Moore (1844-1926), had his own Almeh rejected because of "indecency" at the 1876 Centennial Exhibition in Philadelphia. ${ }^{167}$ The two other twists introduced by Berndtson, the daytime setting of the scene and the attire of the male sitters, cannot be but deliberate. The artist's astute deviations from actual circumstance instil ambiguity in the meaning conveyed. Is the canvas portraying European men just enjoying, in fact or fantasy, Egyptian belly dancing at its extreme, or were they longing for the incorporation of bee dancing into ballet repertoire? The enigma illustrates how challenging visual readings can be.

The subjectivities and ambiguities of Berndtson's Intérieur de salon arabe au Caire, as the piece was named whilein the possessionofDelortdeGléon, ${ }^{168}$ make it a highly original and effective artwork. (Fig. 171) It validates, in the reverse, a maxim of Gustave Moreau: "Where there is no mystery nor superior and divine transformation, there is no art, there is only artifice." 169 Seen from afar, the piece qualifies for Orientalist art; at close glance, it goes way beyond that pictorial genre. The small oil painting does not pretend to represent Middle Eastern people: Europeans feature openly and prominently in the painted scene. Intentionally

166 Peter Cooke, 'It isn't a Dance': Gustave Moreau's "Salome" and "The Apparition", Dance Research: The Journal of the Society for Dance Research 29, No. 2 (Winter 2011): 214-32.

167 Kimberly Orcutt, "H.H. Moore's Almeh and the politics of the Centennial Exhibition," American Art 21, no. 1 (2007): 51-73.

168 Pierrefitte-sur-Seine, Archives nationales, Archives des musées nationaux, Mobilier et objets d'art, Dons et legs, Legs de Mme Delort de Gléon, 9 March 1914, $20144787 / 17$ (the canvas is mentioned in an early will dated 1st July 1905).

169 Gustave Moreau, Écrits sur l'art, ed. Peter Cooke (Paris: Éditions Fata Morgana, 2002), II: 227. 


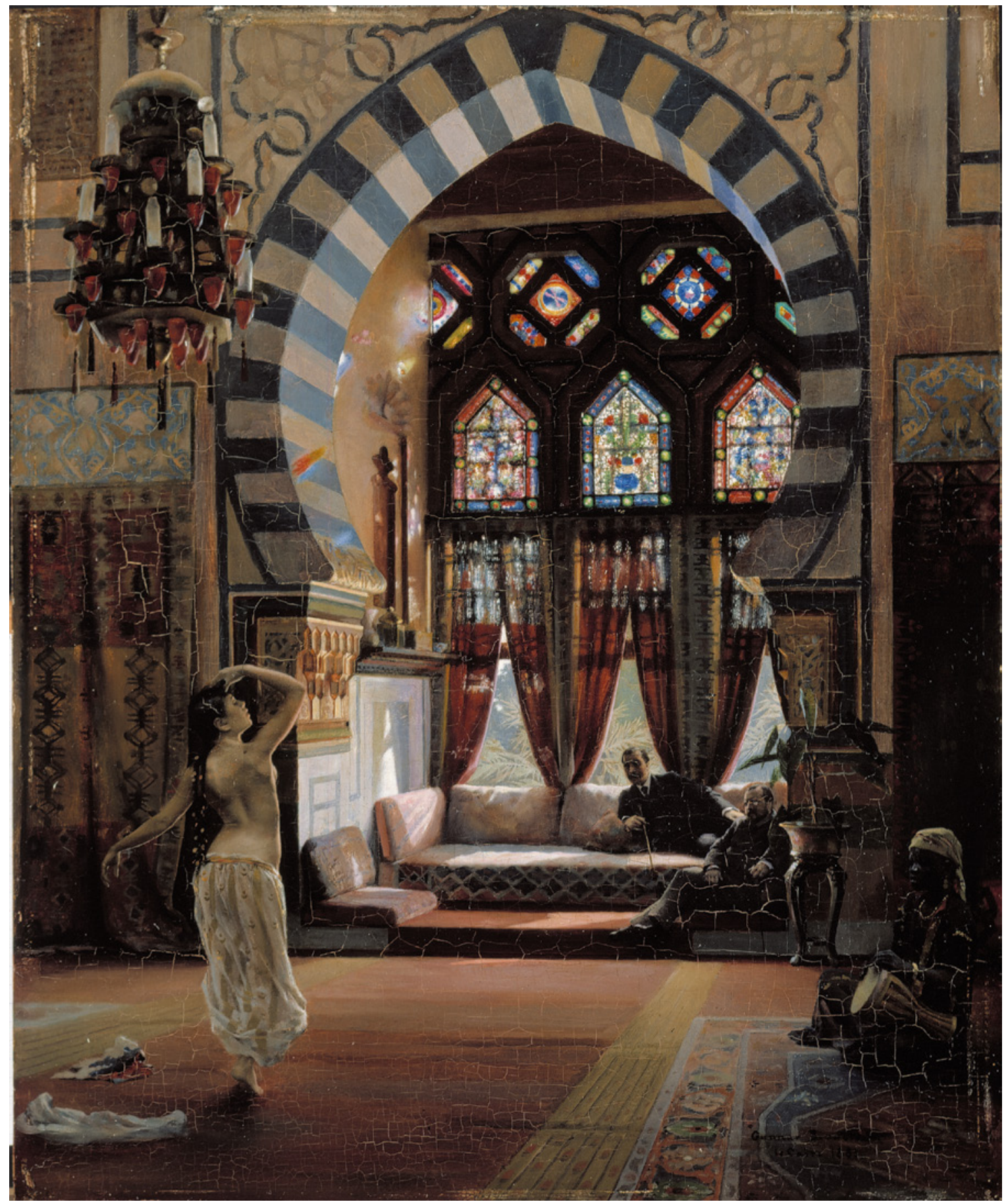

FIGURE 17

Gunnar Berndtson, Almée, an Egyptian Dancer, 1883 [initially known as Intérieur de salon arabe au Caire]. Oil on panel. $45 \times 37.5 \mathrm{~cm}$

HELSINKi, FINNISH NATIONAL GALLERY/ATENEUM ART MUSEUM, ANTELL COLLECTIONS, A II 1396 
or not, the piece provides a Europeanised version of belly dancing, or is it an Orientalised version of classical dance that was intended? Furthermore, could it be a transposition of the biblical Salomé and Herod into nineteenth-century French Cairo? Whatever the case, the artwork tackles the issue of cultural confrontation, and at the same time, the limits of the European appropriation of Middle Eastern culture. It is neither an Orientalist group portrait, nor a genre scene strictly speaking; it is a portrayal of interculturality in the making, socially, temporally and artistically.

Another member of Gérôme's entourage, the artist Charles Bargue (1826-1883), had also produced his own Almée a few years earlier. (Fig. 172) The discreetly attired performer stands alone in front of elaborate woodwork; tiles can be identified in the background. The ceramic panel is fictitious, but the inlaid doors, the symmetrical pairs of griffons over them and the large basin, among other items, are not. All belong to the art dealer Albert Goupil; the collectibles were to be repurposed in a corner of his Parisian Galerie orientale, mentioned in Chapter 4. (Fig. 173) (Gérôme used the same corner for another of his Almehs. ${ }^{170}$ ) Bargue's small size oil had been commissioned by the American collector William H. Vanderbilt through Goupil's agent in the US; curiously enough, the painting was meant for public consumption, for it was on loan to the Met from 1886 to 1903 , rather than for private viewing as the licentious connotation associated with dancing might have suggested. ${ }^{171}$

In contrast to Berndtson's take on the topic, Bargue's composition is pure fiction. The Islamic artefacts in the background contribute some plausibility to the scene. Yet, it is the costume that authenticates it. Bargue never travelled East,

170 La Chanteuse [sic], c. 188o (Huntington, NY, The Heckscher Museum of Art, August Heckscher Collection, 1959.177).

171 Christie's New York, 19th Century European Paintings, Drawings, Watercolors \& Sculpture, 1-2 November 1995, Sale 828 , lot 46 (62).

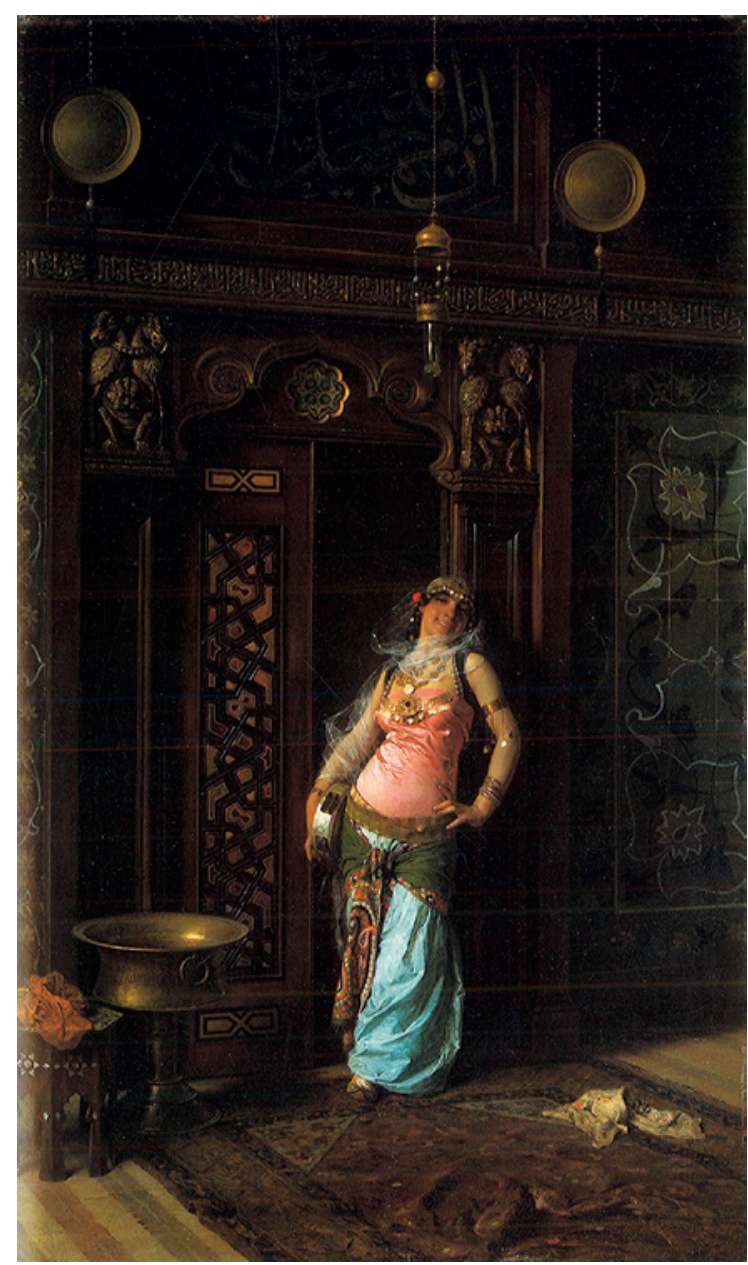

FIGURE 172 Charles Bargue, L'Almée, 1879. Oil on panel. $41.6 \times 24.5 \mathrm{~cm}$

AUCTIONED ON 1ST NOVEMBER 1995,

CHRISTIE'S NEW YORK, LOT 46. CURRENT LOCATION UNKNOWN

as far as is known. ${ }^{172}$ But he could get the prop from Gérôme, with whom he shared a studio, or through the well-established Parisian costumer Gaston Courtois, whose collection of historic attire

172 Little is known on the artist, besides the information gathered by Gerald Ackerman in his introduction to Charles Bargue avec le concours de Jean-Léon Gérôme: Cours de dessin (Paris: ACR Édition, 2011). 


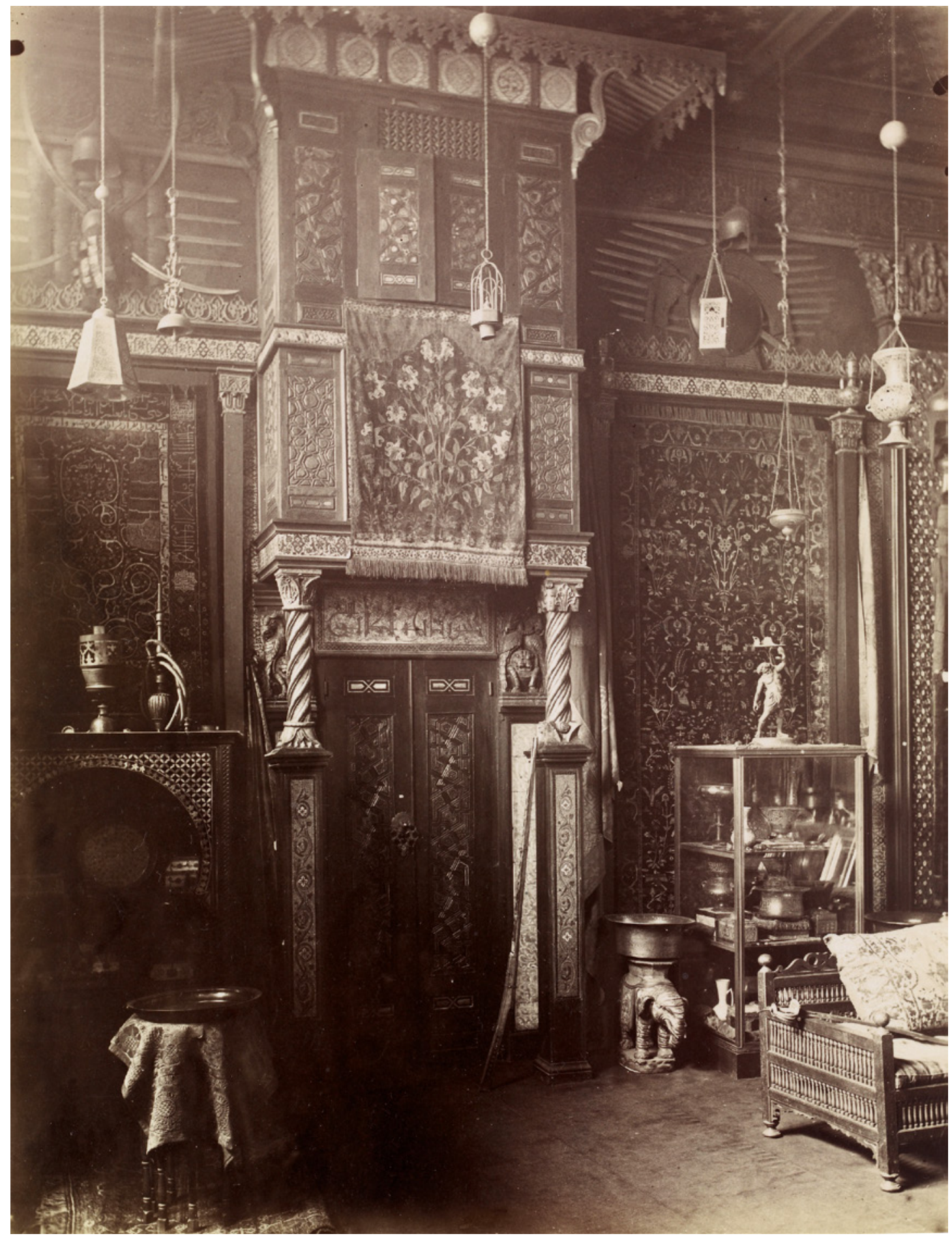

FIGURE 173 Edmond Bénard, Untitled [Corner of Albert Goupil's Oriental Gallery at 9 Chaptal St., Paris] c. $1884-88$. Albumen print. $26.9 \times 20 \mathrm{~cm}$ EDMOND BÉNARD, INTÉRIEURS PRIVÉS D'ARTISTES. ATELIERS D'ARTISTES, 1880-1910, NO. 34. PARIS, BIBLIOTHÈQUE DE L'INHA, 4 PHOT 021 


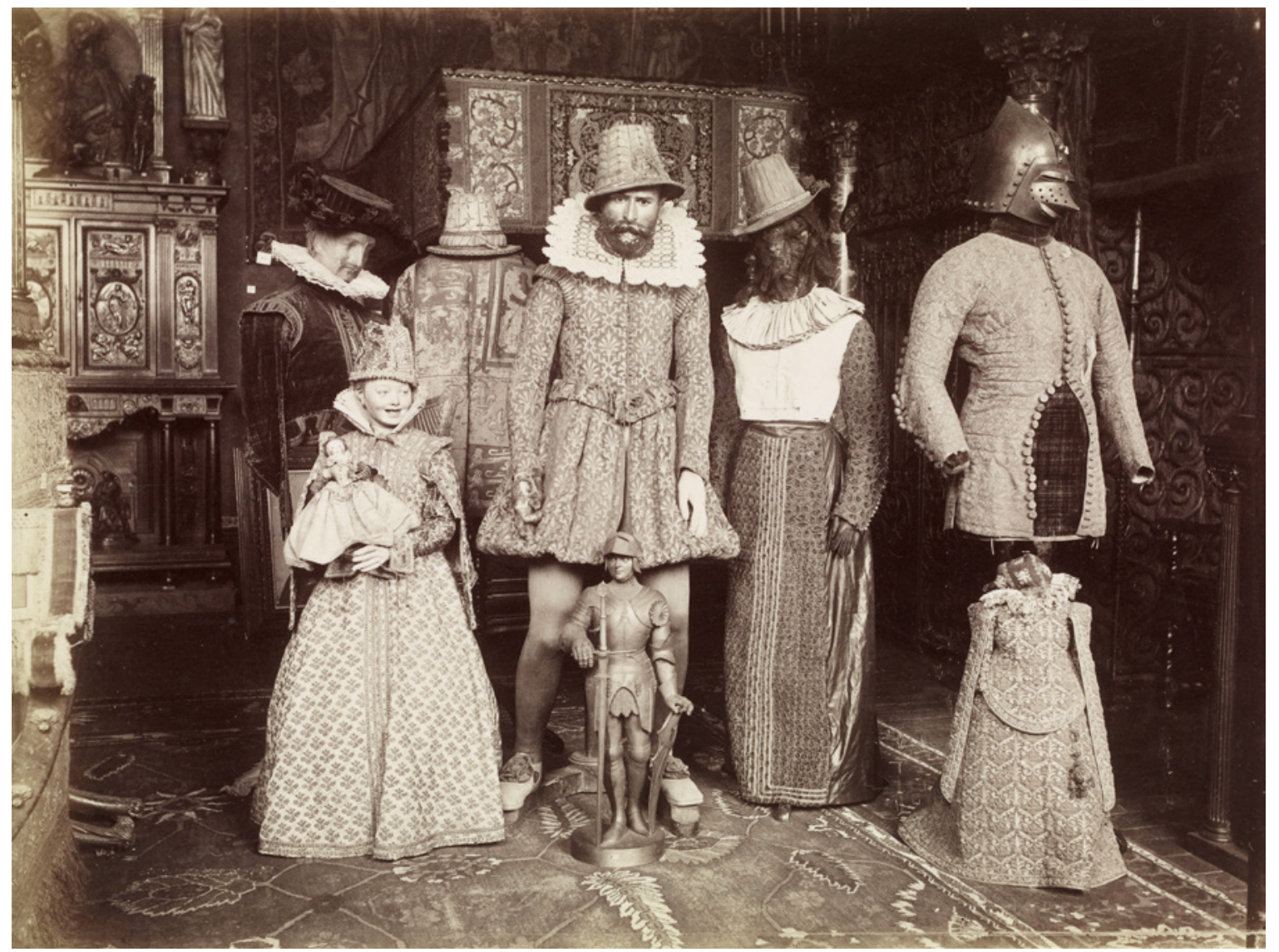

FIGURE 174 Edmond Bénard, Untitled [Clothed mannequins in the Renaissance Gallery installed by Albert Goupil at 9 Chaptal St. in Paris], c. $1884-88$. Albumen print. $20.5 \times 27.3 \mathrm{~cm}$ EDMOND BÉNARD, INTÉRIEURS PRIVÉS D'ARTISTES. ATELIERS D'ARTISTES, 1880-1910, NO. 21. PARIS, BIBLIOTHÈQUE DE L'INHA, 4 PHOT 021

had included at least three Almeh sets. ${ }^{173}$ Goupil might have secured the costume too, for his collections included many historic garments. ${ }^{174} \mathrm{He}$ was particularly fond of pieces from the Renaissance, and used to clothe wooden mannequins in them.

173 Catalogue des costumes anciens et reconstitués militaires et civils des $X I V^{e}, X V^{e}, X V I^{e}, X V I I^{e}$ et $X V I I I^{e}$ siècles, à l'usage des artistes peintres et sculpteurs, le tout dépendant des collections de Gaston Courtois, sale 14-17 December 1891 [Lugt 50338], no. 1203, 1253-54.

174 No almée costume is however mentioned in his sale catalogue; Catalogue des objets d'art de l'Orient et de l'Occident. Tableaux, dessins, composant la collection de feu M. Albert Goupil (Paris: Imprimerie de l'art, 1888).
(Fig. 174) The dressed up figures made an astounding vision that impressed more than one visitor:

Dans cet ensemble s'imposait une surprise d'un effet un peu théâtral. Au-dessous du long vitrail $[\ldots]$, s'élevait une large et haute vitrine [...] dans laquelle semblaient vous recevoir quelques mannequins bien faits, aux visages peints sans recherche de naturisme excessif, revêtus de costumes authentiques de grands seigneurs. Du groupe se détachaient deux mignonnes infantes souriantes [...] Ces apparitions n'avaient pas le caractère vilainement impressionnant des bonhommes des 
musées de cire, car on s'était gardé de rechercher l'exactitude trompe-l'œil hallucinante. Non, on pouvait s'imaginer être reçu par les ombres idéalisées des anciens profiteurs de toutes ces belles choses, heureux de voir apprécier par d'autres ce qu'ils avaient euxmêmes admiré et aimé. ${ }^{175}$

The mode of display privileged by Goupil was seen as "theatrical." It echoed the idea of the "living museum."176 Although inanimate, clothed mannequins were seen as bringing extra life, in the same way they did in Moser's Eastern armoury mentioned at the opening of the chapter. At stake was the recreation not only of an historic interior, but of an historic atmosphere, away from the scary prospect of likenesses characterising waxwork. Ultimately, stimulating the imagination mattered more than perfect accuracy.

One last meaningful, albeit later, example adds a new layer to the practice of animating inanimate places. It is connected to the Islamic style rooms fashioned in Paris by scholar and collector Henry-René D’Allemagne (1863-1950). The interiors occupied the first three floors of his Parisian

175 Zamacoïs, Pinceaux et stylos, 103-04. "[The rooms] imposed a surprise of some theatrical effect. Under a long stained-glass bay, stood a large and tall show case [...] where one was sort of welcomed by well-executed dummies, with faces painted without excessive naturalism, wearing authentic costumes of grandees. Two charming and smiling young princesses distinguished themselves in the group. [...] These apparitions did not possess the scary characteristic of figures in wax museums, because accurate optical illusions capable of prompting hallucinations had not been sought out. No, one could imagine being received by the idealised shadows of the previous owners of all these beautiful things, being happy to see appreciated by others what they had themselves appreciated and loved." [My translation]

176 Elizabeth Emery, Laura Morowitz, "From the living room to the museum and back again: The collection and display of medieval art in the fin de siècle," Journal of the History of Collections 16, no. 2 (November 2004): 285-309. hôtel particulier [mansion], and most had been installed in 1903-06 by artist and decorator Julien Godon (1839-1915), an expert in painted tapestry, i.e. in illusory effects. Their arrangements are illustrated in detail in a photographic album published by D'Allemagne in 1939. (Fig. 175) Two of the plates include individuals; they are among the few coloured ones. The sitters were two Persian dancers, Nahidé and Medjid Rezvani, who had given a concert in one of the rooms, and "had accepted posing to animate by their presence one of its corners." ${ }^{177}$ At the bottom of their double coloured portrait, was a verse from Persian love poetry attributed to Omar Khayyam, but ill-written. ${ }^{178}$ (Fig. 176) The couple had arrived in France at the end of 1931, where their performances had caused a sensation. Accompanied by a player of $t \bar{a} r$ [a Persian long-necked, waisted string instrument], they interpreted Iranian dances and pantomimes, from court and popular repertoire, which were completely new to French audiences. Persian dance was mostly known then only from the iconography of miniatures. ${ }^{179}$ The room that the couple had gracefully agreed to "animate" had made its way to Paris from Damascus in 1920, through a chain of intermediaries. ${ }^{180}$ It belonged to the 'ajami [Persian] style; as seen in Chapter 4, the term applied to a decorative technique characteristic of

\footnotetext{
177 Henry-René D’Allemagne, Réminiscence d'Orient. Turquie - Perse et Syrie, Ouvrage contenant 3 o planches en phototypie et six planches coloriées à l'aquarelle (Paris: D'Allemagne, 1939), pl. xırbis and xvbis.

178 My gratitude to Elaheh Habibi for checking the verse for me.

179 "Au Théâtre de la Madeleine: Nahidé et Medjid Rezvani dans leurs danses persanes," La Rampe, revue des théâtres et music-halls, 1st June 1932, 23 (with their portrait). The couple fathered the reputed artist of the Nouvelle Vague Serge Rezvani.

180 Identified by a French Officer among the ruins of a house bombarded during the early days of the French mandate, negotiated with its Syrian owner, and imported to France by the Parisian cabinet-makers Perret and Vibert, the room had been installed in a previous residence, before being repurposed at D'Allemagne's; D'Allemagne, Réminiscence d'Orient, 12.
} 


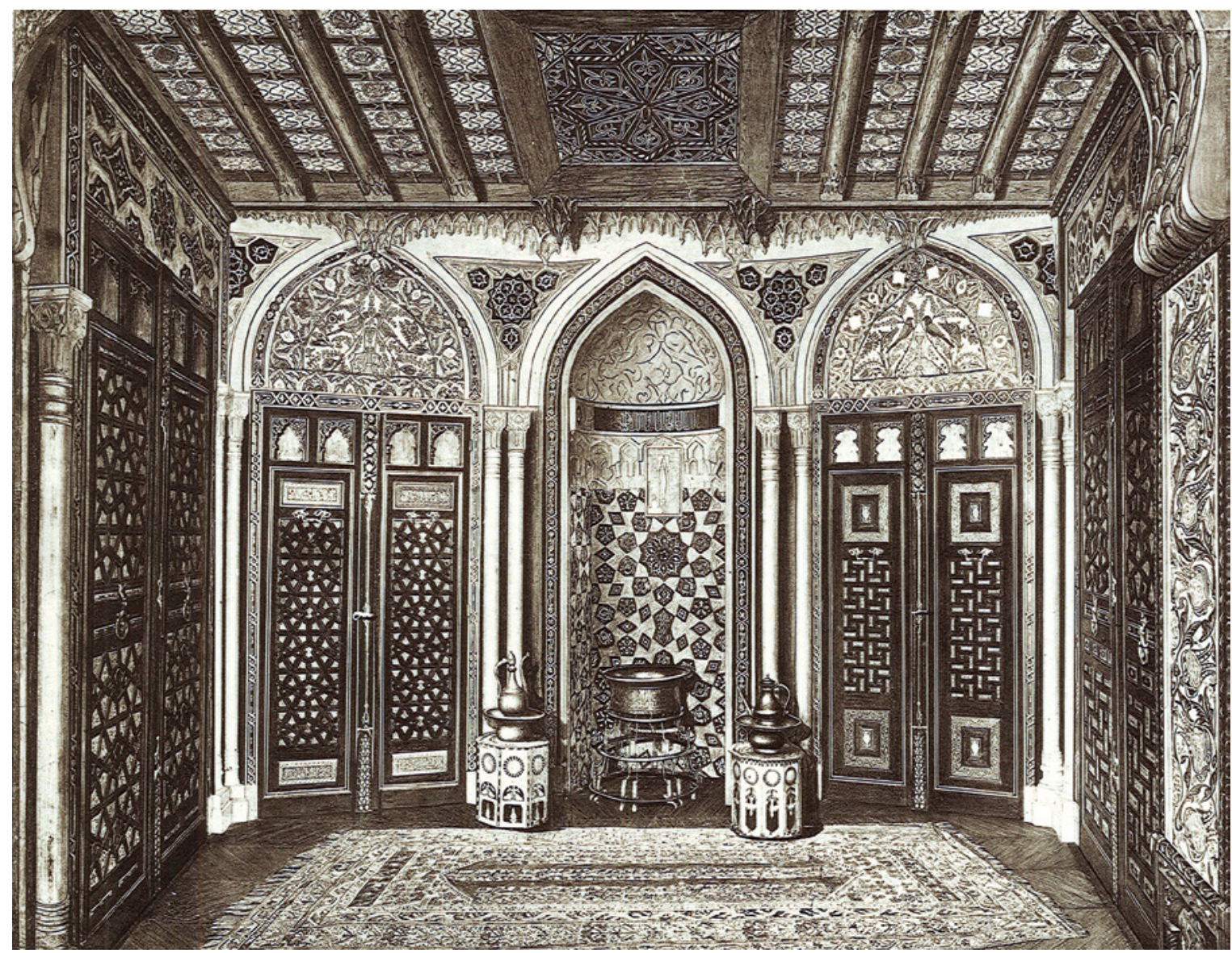

FIGURE 175 Anonymous, Vestibule d'entrée [Entrance to Henry-René D’Allemagne's Middle Eastern rooms, at 30 Mathurins St. in Paris], c. 1932. Phototype handcoloured in watercolour. $21 \times 16 \mathrm{~cm}$

HENRY-RENÉ D'ALLEMAGNE, RÉMINISCENCE D'ORIENT. TURQUIE - PERSE ET SYRIE, 1939: PL. I

Ottoman Syria that consisted in applying a thick gesso to the wood before painting it with floral iconography, along a manner that had originated in Persia. The costumes of the couple may have come from D'Allemagne's collection. He did possess nineteenth-century embroidered khalat [robe in Persian] in red and yellow silk, similar to the ones donned by the two artists. ${ }^{181}$

181 Henry-René D'Allemagne, Du Khorassan au pays des Backhtiaris, trois mois de voyage en Perse (Paris: Hachette, 1911), II: plate facing 10.
4

\section{A Gendered Collecting Culture}

The coloured portrait of Nahidé and Medjid Rezvani in D'Allemagne's 'ajamī room brings together again a number of threads already encountered throughout this chapter. They are intertwined in this instance under a Persian theme: the decorative technique of a salvaged and repurposed room, a live performance taking place in its setting, the donning of matching costumes, worn in this case by two Persian artists coming from Iran. The combination points to a pattern shared by many a collector: a mania for matching every possible element, from interior design to props to attire, to people, and to performance. 
PLANCHE XVM.
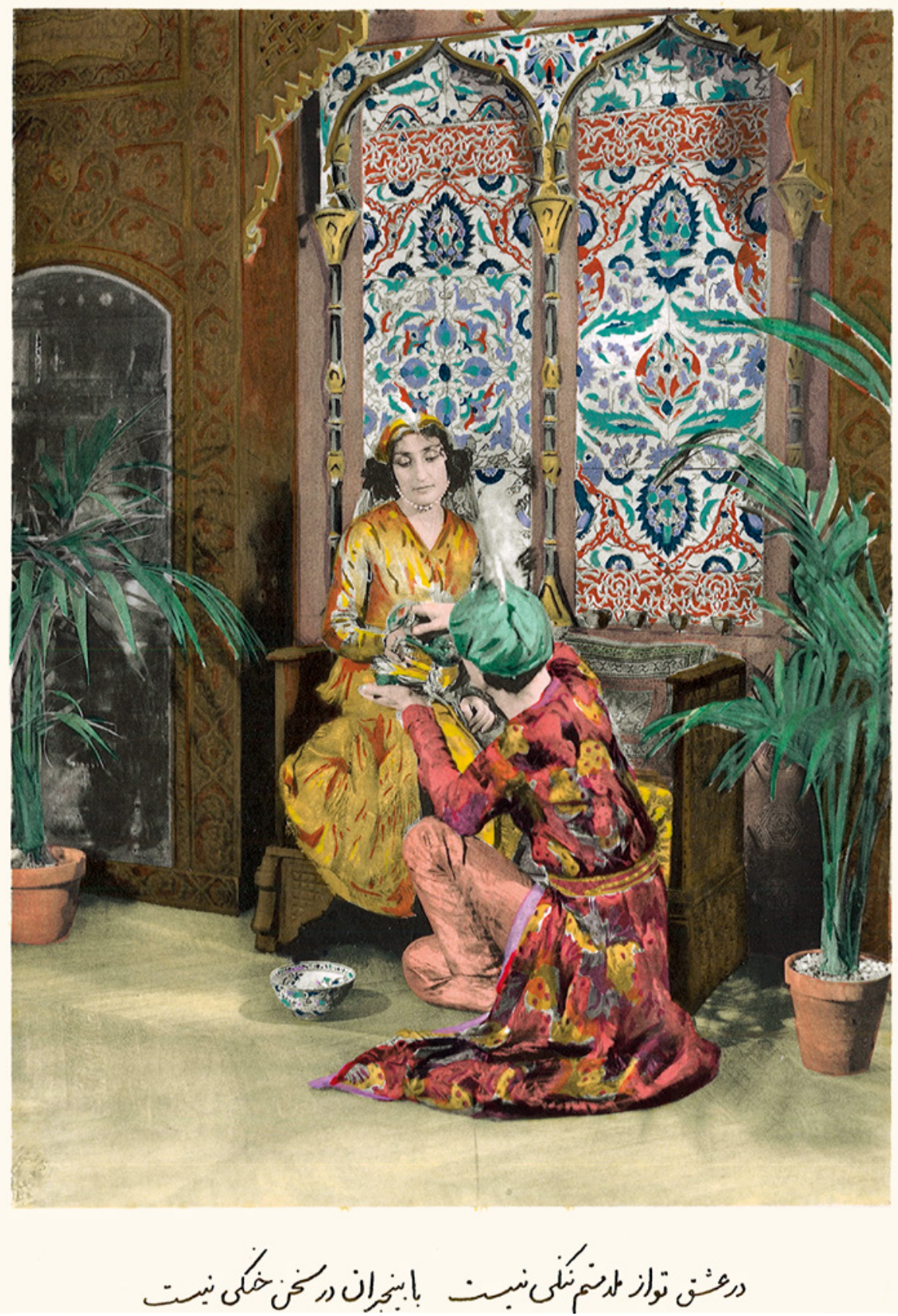

FIGURE 176 Anonymous, Concert donné au bord de la fontaine par deux artistes persans, M. et Mme Rezvani [Nahidé and Medjid Rezvani, posing in D'Allemagne's 'ajamı̄ room, at 30 Mathurins St. in Paris], c. 1932. Phototype handcoloured in watercolour. $21 \times 16 \mathrm{~cm}$ HENRY-RENÉ D'ALLEMAGNE, RÉMINISCENCE D'ORIENT. TURQUIE - PERSE ET SYRIE 1939: PL. XVBIS 
Arranging Islamic style rooms and wearing Middle Eastern attire represented two faces of the same coin: the ultimate end was to engineer a "metamorphosis" of the self - the substantive appears recurrently in narratives and correspondence. The transformation encompassed one's own space and the ways bodies inhabited it. The rest was a matter of nuances and possibilities: the transformation could be ephemeral or more lasting, more or less seriously pursued and successfully achieved; a range of agendas intervened. The broader context of codified attire in Ottoman lands was a determining factor. In most cases, cross-cultural dressing involved personal interactions of Europeans with people in the Middle East. These interplays have to be read more often than not in between the lines. They were not necessary meant to become public. That the encounters can be grasped through artworks of small- or mediumsize format, and paintings long kept private, tells that their visual interpretations were not made for public impression but rather for private viewing and sharing. The privately-held nature of this iconography also explains why it has never been considered as a subgenre per se, within, or indeed beside, visual Orientalism, but it qualifies to be analysed on its own terms, as personal souvenirs of travel and, more broadly speaking, depictions of interculturality. Paintings in this manner may appear in fact more numerous than expected, once full attention, grounded on historical evidence, is paid to the figuration of art in relation to the East. At closer look, more often than not, what the artworks may reveal, are not Western fantasies of non-Western people, but concrete cross-cultural interactions in the East. Famars Testas' souvenir of an evening in the Fayyum is an obvious example. Others are less easily detected for they involve Europeans dressed as natives. When properly scrutinised, a genre scene may ultimately emerge as the picturing of an actual episode of interculturality, as demonstrated by Vernet's Voyage dans le désert. I have discussed a series of examples here, and in previous works; ${ }^{182}$ I believe more are to be uncovered. ${ }^{183}$

On the other hand, Vernet's attention to costume, as fully fleshed out in his 1848 talk, is a perfect demonstration of why costume mattered to artists, and how dress related to historical thinking then, and from there entered the world of historicist art.

A further conclusion to be drawn from the realities and depictions analysed in this chapter relates to masculinity. The phenomenon of cross-cultural dressing and cross-cultural decorating at the time shared more than being ways to metamorphose the self and transform one's space accordingly. They possess a gendered dimension that cannot be escaped. It represents first and foremost a male world, at least throughout the nineteenth century. Actual portraits in Eastern attire primarily involve male characters. Disguised women appear mostly in genre scenes. A similar fragmentation also links most elaborated interiors encountered so far, and the social life developing within their walls. Many were typically pursued by bachelor aesthetes, with substantial means at their disposal, whether through old or new money. An analysis of an equivalent pursuit - fashioning Japanesque interiors in Paris - has highlighted the same reality. ${ }^{184}$ It has been hypothesised that bachelorhood, and moreover the outright rejection of domesticity, were the key determinants for this specific, highly

182 Mercedes Volait, "Émile Prisse d'Avennes au travail: un art de la collecte et de la compilation," in Émile Prisse d'Avennes (1807-1879), 75-102.

183 Mercedes Volait, "Scène de genre, choses vues ou attrait du travestissement? Les Européens dans la peinture orientaliste," in L'Orientalisme après la Querelle: dans les pas de François Pouillon, eds. Guy Barthèlemy, Dominique Casajus, Sylvette Larzul and Mercedes Volait, (Paris: Éditions Karthala, 2016), 37-49.

184 Christopher Reed, "Bachelor quarters: Spaces of Japonisme in nineteenth-century Paris," in Oriental Interiors: Design, Identity, Space, ed. John Potvin (London: Bloomsbury Academic, 2015), 111-26. 
gendered, collecting culture. ${ }^{185}$ Most collectors surveyed in these pages fit this homosocial pattern.

Finally, the lightness and pleasure involved in shaping one's interior or one's semblance should not be ignored either. It has been argued that cultural cross-dressing gathered momentum "because it was based on humor, play, transformation and

185 Christopher Reed, ed., Not at Home: The Suppression of Domesticity in Modern Art and Architecture (London: Thames and Hudson, 1996). transgression."186 Creating rooms meant to be "total environments" 187 or donning full Middle Eastern apparel appealed to those who could afford it, for it was ... enjoyable. It was a full-time occupation, and one propitious for social interaction and pleasurable entertainment. It contributed ultimately to one's own well-being.

186 Thoral, "Sartorial Orientalism," 6o.

187 Anne Higonnet, A Museum of One's Own. Private Collection, Public Gift (Pittsburgh: Periscope, 2010). 